Asymmetric Electrophilic $\alpha$-Amidoalkylation, VII ${ }^{1}$ :

\title{
Generation, Crystal Structure, and Trapping Reactions of a Chiral 6,7-Dimethoxy-1,2,3,4-tetrahydroisoquinoline Derived N-Acyliminium
} Ion

Klaus Th. Wannera ${ }^{\text {* }}$, Ilona Praschak ${ }^{a}$, and Ulrich Nagel ${ }^{\text {b) }}$

a) Institut für Pharmazie und Lebensmittelchemie der Universität München, Sophienstr. 10,8000 München 2

b) Institut für Anorganische Chemie der Universität München, Meiserstr. 1, 8000 München 2

Received May 8, 1989

The camphanic acid amide 4 has efficiently been oxidized with triphenylcarbenium tetrafluoroborate (3) to yield the chiral $\mathrm{N}$-acyliminium ion 1 . Trapping reactions of 1 with the silyl nucleophiles 7a-c and 10a-f proceeded with stereoselective bond formation, affording the diastereomers (R)-8/(S)-9a-c and $(R)-11 /(S)-12 a-f$, respectively, with diastereoselectivities of up to 93.9/6.1.

The amido ketones $(\mathrm{R})-8 /(\mathrm{S})-9 \mathrm{a}-\mathrm{c}$ were employed in the synthesis of the secondary amines (R)-16a-c, (S)-16a and for the preparation of (-)-homolaudanosine (R)-18.

By X-ray crystallography the conformation of 1 in the crystal lattice was established and the preferred conformation of 1 in solution was elucidated by NOE experiments. Finally, the addition reaction of $7 \mathrm{a}$ to the iminium ion 21 derived from menthyl carbamate 20 was investigated, which reaction, however, proceeded only with insignificant asymmetric induction.

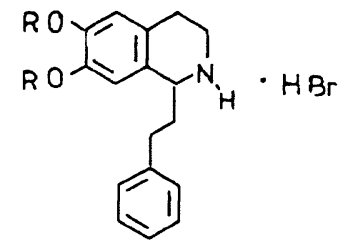

$\begin{array}{ll}\text { I a } & \mathrm{R}=\mathrm{H} \\ \text { Ib } & \mathrm{R}=\mathrm{COCH}_{3}\end{array}$

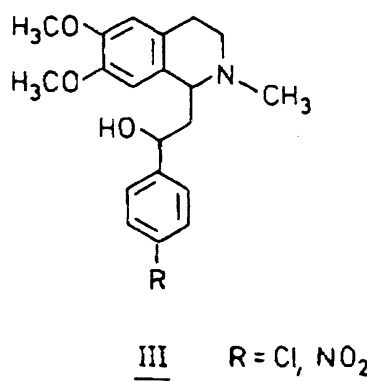<smiles>COc1cc2c(cc1OC)C(CCc1ccc(Cl)cc1)N(C)CC2</smiles>

II<smiles>COc1ccc(CC[C@@H]2c3cc(OC)c(OC)cc3CCN2C)cc1OC</smiles>

IV
Asymmetrische Elektrophile $\alpha$-Amidoalkylierung, 7. Mitt. ${ }^{1)}$ :

Erzeugung, Kristallstruktur und Abfangreaktionen eines chiralen von 6,7-Dimethoxy-1,2,3,4-tetrahydroisochinolin abgeleiteten N-Acyliminiumions

Aus dem Camphansäureamid 4 lieB sich durch Oxidation mit Triphenylcarbeniumtetrafluoroborat (3) sehr effizient das chirale $\mathrm{N}$-Acyliminiumion 1 herstellen. Abfangreaktionen von 1 mit den Silylderivaten $7 \mathrm{a}-\mathrm{c}$ und 10a-f

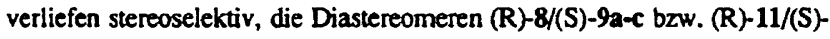
12a-f wurden mit Diastereoselektivitäten bis zu 93.9/6.1 erhalten. Die Amidoketone (R)-8/(S)-9a-c wurden zur Synthese der sekundären Amine (R)16a-c, (S)-16a und fur die Darstellung von Homolaudanosin (R)-18 herangezogen. Die Konformation von 1 im Kristallgitter wurde durch Röntgenstrukturanalyse bestimmt, und NOE-Experimente gestaneten Ruckschlisse auf die in Losung vorterrschende Konformation. - SchlieBlich wurde noch die Additionsreaktion von 7a an das Iminiumion 21, das sich vom Menthylcarbamat 20 ableitet, untersucht, die jedoch ohne nennenswerte asymmetrische Induktion verlief. 
IV is a typical representative of those alkaloids. Therefore, it appeared very tempting to us to develop a new route to this type of compounds in enantiomerically pure form ${ }^{6}$.

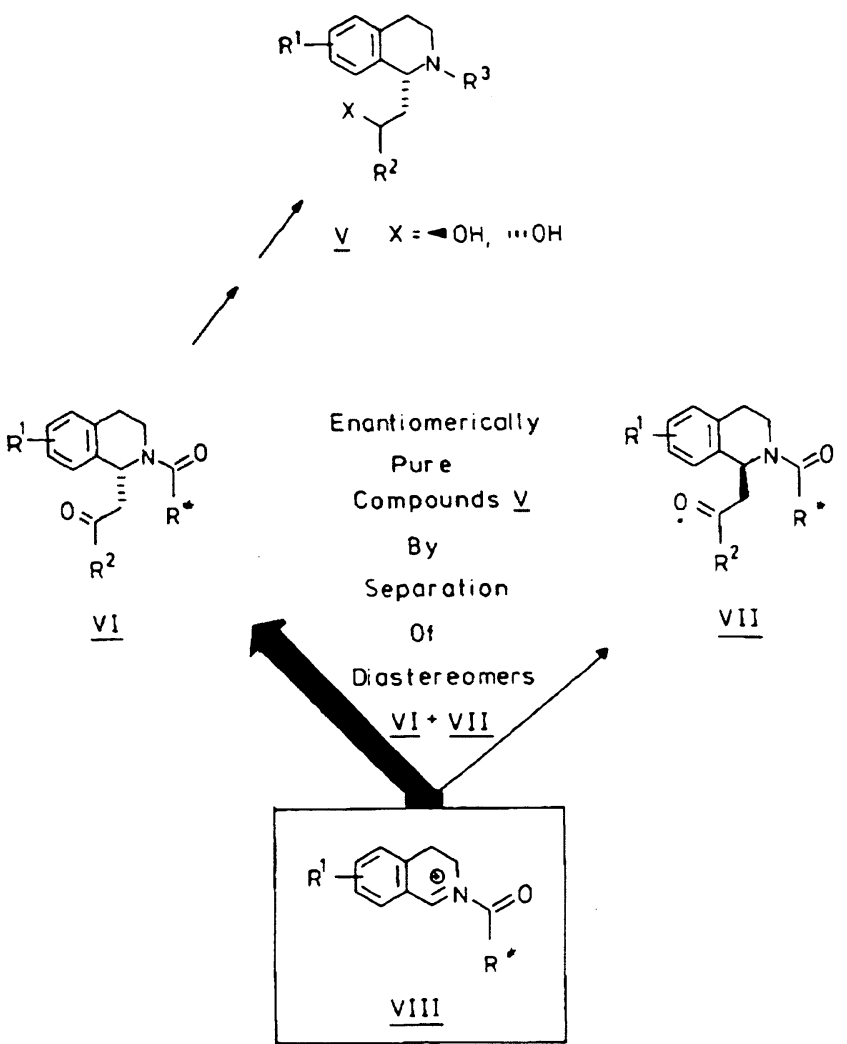

The Asymmetric Electrophilic $\alpha$-Amidoalkylation (AE $\alpha A$ ) is a general concept we have developed for the preparation of enantiomerically pure secondary amines with a chiral center in $\alpha$ position with respect to nitrogen and that we have already employed in the synthesis of pyrrolidines ${ }^{7)}$ and piperidines ${ }^{8}$. Electrophilic $\alpha$-amidoalkylation involves the linkage of an amido alkyl group to another molecule via the $\alpha$-carbon atom of an intermediate $\mathrm{N}$-acyliminium ion (the electrophile). The key step of the AE $\alpha \mathrm{A}$ is the diastereoselective trapping reaction of an acyliminium ion (e.g. VIII) by a nucleophile as outlined for isoquinolines in Scheme 2 (VIII $\rightarrow$ VI + VII), wherein a chiral acyl group $\left(R^{\mathrm{x}} \mathrm{CO}\right)$ gives rise to the asymmetric induction. As a result one diastereomer should prevail. Provided a suitable nucleophile has been employed that diastereomer may be an $\alpha$-amidoketone, e.g. VI. Eventually amines $V(X=H)$ or aminoalkohols $V(X=O H)$ can be obtained from VI by simple reduction and subsequent removal of the chiral auxiliary $R^{x} C O$. It should be stressed that this sequence reliably affords the final product in enantiomerically pure form if VI is employed in the form of a single diastereomer. That diastereomer can be obtained by conventional methods such as chromatography and crystallisation.

In this paper we wish to report in detail ${ }^{9)}$ the successfull implementation of the above concept in the synthesis of 1-phenyl-ethylamines $V\left(X=H, R^{2}=A r\right)$.

\section{Generation of N-Camphanoyl-3,4-dihydroisoquinolinium Ion 1}

We chose (-)-camphanic acid as chiral auxiliary since it can be regarded as configurationally stable. Considering the substitution of the analgesics mentioned above it appeared attractive to generate the acyliminium ion 1.

For this purpose, amide 4 was prepared from the tetrahydro isoquinolinium chloride 5 and (-)-camphanic acid chloride (6) in $90.4 \%$ yield. A method frequently used for the conversion of tertiary amides to acyliminium ions involves the preparation of $\alpha$-methoxyamides as synthetic intermediates by means of electrochemical oxidation ${ }^{10}$. Therefore, we subjected 4 dissolved in $\mathrm{CH}_{3} \mathrm{OH}$ in the presence of the electrolyte $\left(\mathrm{CH}_{3}\right)_{4} \mathrm{~N}^{+} \mathrm{BF}_{4}{ }^{-}$to anodic oxidation. In this oxidation the starting material $\mathbf{4}$ was completely consumed within a few h but no defined product could be detected (TLC). Next we focused our attention on oxidations of amides by means of organic compounds.

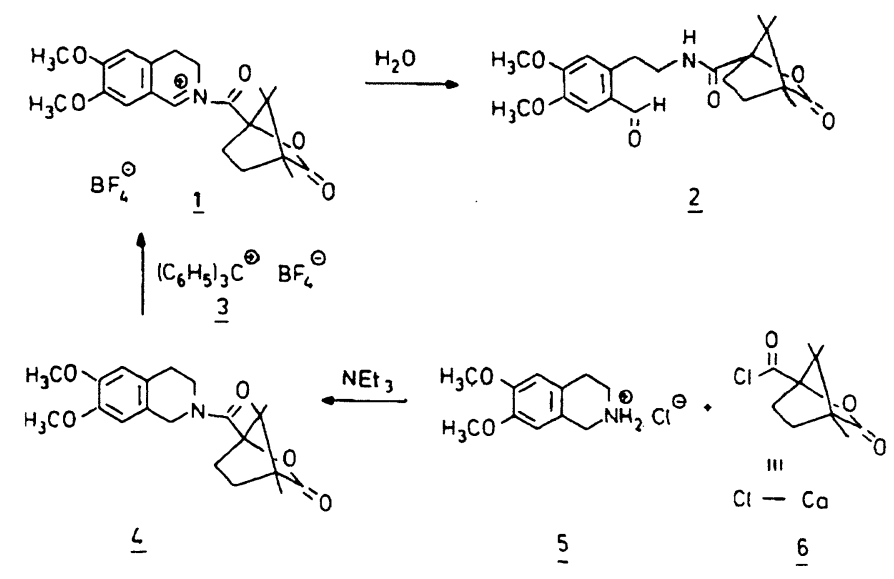

As oxidation of a structurally related amide (amide nitrogen in benzylic position) with 2,3-dichloro-4,5-dicyanop-benzoquinone ${ }^{11)}$ (DDQ) had been reported we treated 4 with DDQ as well $\left(\mathrm{CH}_{2} \mathrm{Cl}_{2},-78^{\circ} \mathrm{C}, 3 \mathrm{~d}\right)$. Indeed, upon aqueous work-up aldehyde 2 could be isolated in about $20 \%$ yield. The formation of $\mathbf{2}$ indicates that the acyliminium ion 1 had been formed, which upon addition of water underwent ring opening to give 2 . Finally we found that by using triphenylcarbenium tetrafluoroborate ${ }^{12)}(3)$ a complete and clean oxidation of 4 can be effected within $16 \mathrm{~h}$, subsequent hydrolysis again leading to $2(26.1 \%$ of pure material; the low yield is due to incomplete separation of $\mathbf{2}$ from a minor side product).

At the concentrations we usually employed in this oxidation reaction always a yellow precipitate occurred with increasing reaction time. As we assumed this precipitate to be the iminium ion 1, it was subjected after recrystallisation to a single crystal $\mathrm{X}$-ray analysis which unequivocally confirmed our assumption (for details on the $\mathrm{X}$-ray analysis see below).

A series of trapping reactions of 1 with different nucleophiles is described below. For this purpose the crude reaction mixture resulting from the oxidation of 4 with 3 was used after having dissolved the precipitate by addition of some extra solvent. 


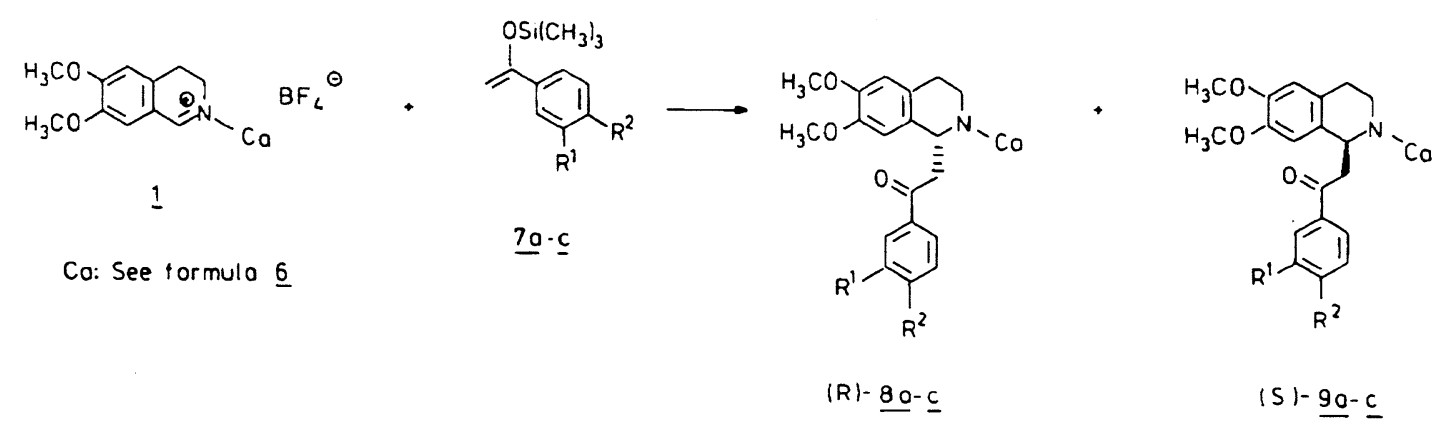

Table 1: Trapping reactions of $\mathrm{N}$-camphanoyl-3,4-dihydroisoquinolinium ion 1 with silyl enol ethers $7 \mathrm{a}$-c.

\begin{tabular}{|c|c|c|c|c|c|c|c|c|c|c|c|}
\hline \multicolumn{4}{|c|}{ Silyl Enol Ether } & \multirow[b]{2}{*}{ equ.-TiCl 4} & \multirow[b]{2}{*}{$\mathrm{T}\left[{ }^{\circ} \mathrm{C}\right]$} & \multirow[b]{2}{*}{$t[h]$} & \multirow[t]{2}{*}{ Product } & \multirow{2}{*}{$\frac{\text { Yield [\%] }}{(\mathrm{R})-8+(\mathrm{S})-9}$} & \multirow{2}{*}{$\frac{(\mathbf{R})-8}{\left.\delta_{\mathrm{H}-1}[\mathrm{ppm}]^{\mathrm{a}}\right)}$} & \multirow{2}{*}{$\frac{\text { Ratio }}{(R)-8 /(S)-9}$} & \multirow{2}{*}{$\frac{(\mathrm{S})-9}{\delta_{\mathrm{H}-1}[\mathrm{ppm}]^{2}}$} \\
\hline & & $\mathbf{R}^{1}$ & $\mathbf{R}^{2}$ & & & & & & & & \\
\hline 1 & $7 \mathbf{a}$ & H & $\mathbf{H}$ & - & -78 & 2 & $8 a / 9 a$ & - & 6.03 & $79.7 / 20.3$ & 6.17 \\
\hline 2 & $"$ & $"$ & $"$ & - & -90 & 2 & $"$ & 97.2 & - & $82.4 / 17.6$ & - \\
\hline 3 & $\ddot{*}$ & $"$ & $"$ & 0.5 & -78 & 2 & $"$ & - & - & $80.2 / 19.8$ & - \\
\hline 4 & $"$ & $"$ & $"$ & 1.0 & .78 & 2 & $"$ & - & - & $87.6 / 12.4$ & - \\
\hline 5 & $"$ & $"$ & $"$ & 1.0 & -93 & 3.5 & $"$ & - & - & $88.8 / 11.2$ & - \\
\hline 6 & $"$ & $"$ & $"$ & 1.5 & -78 & 1.5 & $"$ & - & - & $88.4 / 11.6$ & - \\
\hline 7 & $"$ & $"$ & $"$ & 2.0 & .78 & 3 & $"$ & - & - & $90.3 / 9.7$ & - \\
\hline 8 & $"$ & $"$ & $"$ & 2.5 & -78 & 2 & $"$ & 77.8 & - & $91.2\left(8.8^{b)}\right.$ & - \\
\hline 9 & $"$ & $"$ & $"$ & 3.0 & -78 & 1.66 & $"$ & - & - & $88.0 / 12.0$ & - \\
\hline 10 & $"$ & $"$ & $"$ & 3.5 & -78 & 2 & $"$ & - & - & $86.5 / 13.5$ & - \\
\hline 11 & $7 \mathrm{~b}$ & H & $\mathrm{Cl}$ & - & -78 & 18 & $8 \mathrm{~b} / 9 \mathrm{~b}$ & 98.9 & 5.98 & $85.2 / 14.8$ & 6.12 \\
\hline 12 & $"$ & $"$ & $"$ & 2.5 & .78 & 2 & $"$ & 84.4 & - & $93.9 / 6.1$ & - \\
\hline 13 & $7 c$ & $\mathrm{OCH}_{3}$ & $\mathrm{OCH}_{3}$ & 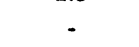 & -78 & 20 & $8 c / 9 c$ & 96.8 & 6.00 & $82.4 / 17.6$ & 6.14 \\
\hline
\end{tabular}

a) Signal of the major conformer recorded at $400 \mathrm{MHz}$.

b) The same experiment carried out on a larger scale resulted in a 91.9/8.1-ratio.

It is well known that acyliminium ions add silyl enol ethers to give amido ketones ${ }^{13}$. So does the chiral acyliminium ion 1 but, of course, stereoselectively. When silyl enol ether 7a derived from acetophenone was added to a solution of 1 in $\mathrm{CH}_{2} \mathrm{Cl}_{2}$ (prepared without isolation of 1 ) at $-78^{\circ} \mathrm{C}$ the diastereomeric amido ketones (R)-8a and (S)-9a were formed in a quite reasonable 79.7/20.3-ratio (Table 1 entry 1 ; determined by HPLC). By lowering the temp. to $-90^{\circ} \mathrm{C}$ this ratio slightly increased to 82.4/17.6 (Tabel 1 entry 2). The diastereomers (R)-8a/(S)-9a were obtained after flash chromatography on silica gel (they are inseparable although various solvents have been tried) in an excellent combined yield of $97.2 \%$ based on amide 4 . The diastereomeric ratios reported for (R)-8a/(S)-9a were determined (as generally, if not stated otherwise) with the crude product (after aqueous work-up) by HPLC. For (R)-8a/(S)-9a as for all other diastereomeric mixtures that proved to be inseparable or only incompletely separable on silica gel ((R)-8a-c/(S)-9a-c, (R)11f/(S)-12f a chiral stationary phase was employed. In addition, in the case of (R)-8a/(S)-9a (as for most of the mixtures inseparable on silica gel) we made use of a preparative chiral column in order to obtain the pure diastereomers in tractable amounts (see Table 1 and 2).
The ${ }^{1} \mathrm{H}-\mathrm{NMR}$-spectra of (R)-8a and (S)-9a recorded at $400 \mathrm{MHz}$ each showed two sets of signals of different intensity. This phenomenon is well known with amides and is due to two different conformations ( $E$ and $Z$ ) caused by hindered rotation around the $\mathrm{N}-\mathrm{CO}$ bond ${ }^{14)}$. From the ${ }^{1} \mathrm{H}$ NMR-spectra of (R)-8a, (S)-9a it can unambigously be concluded that these compounds have the constitution shown. The major isomer ( $R$ )-8a has been assigned $R$-configuration for the newly created chiral center by chemical conversion (see below). The proton attached to this stereogenic carbon (C-1 of the isoquinoline nucleus) is very sensitive to its stereochemical environment. In the case of the major isomer, (R)-8a, it resonates at distinctly higher field $(\mathrm{H}-1 ; \boldsymbol{\delta}$ $=6.03 \mathrm{ppm}$; signal of the major conformer of the major isomer) as compared to the one of the minor isomer ( $\mathrm{H}-1: \delta$ $=6.17 \mathrm{ppm}$; major conformer of the minor isomer). This trend was observed for substituted compounds (R)-8b-c/(S)9b-c as well (see Table 1).

It occurred to us that it might be possible even to increase the diastereoselectivities observed so far by addition of a Lewis acid. Addition of 0.5 equiv. of $\mathrm{TiCl}_{4}$ to 1 prior to the addition of silyl enol ether did not afford a significant effect (compare Table 1, entry 3 to entry 1). However, upon 


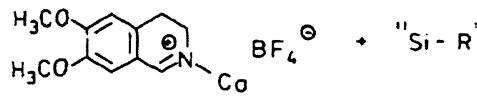

1

$\underline{100}-\underline{f}$

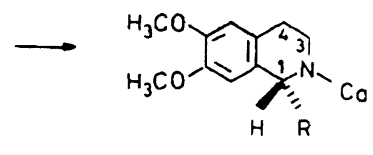

$(R)-110-f$

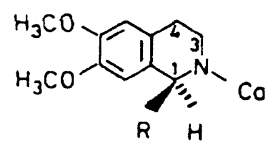

(S) $-120-1$

Table 2: Trapping reactions of $\mathrm{N}$-camphanoyl-3,4-dihydroisoquinolinium ion 1 with silicon reagents 10a-f.

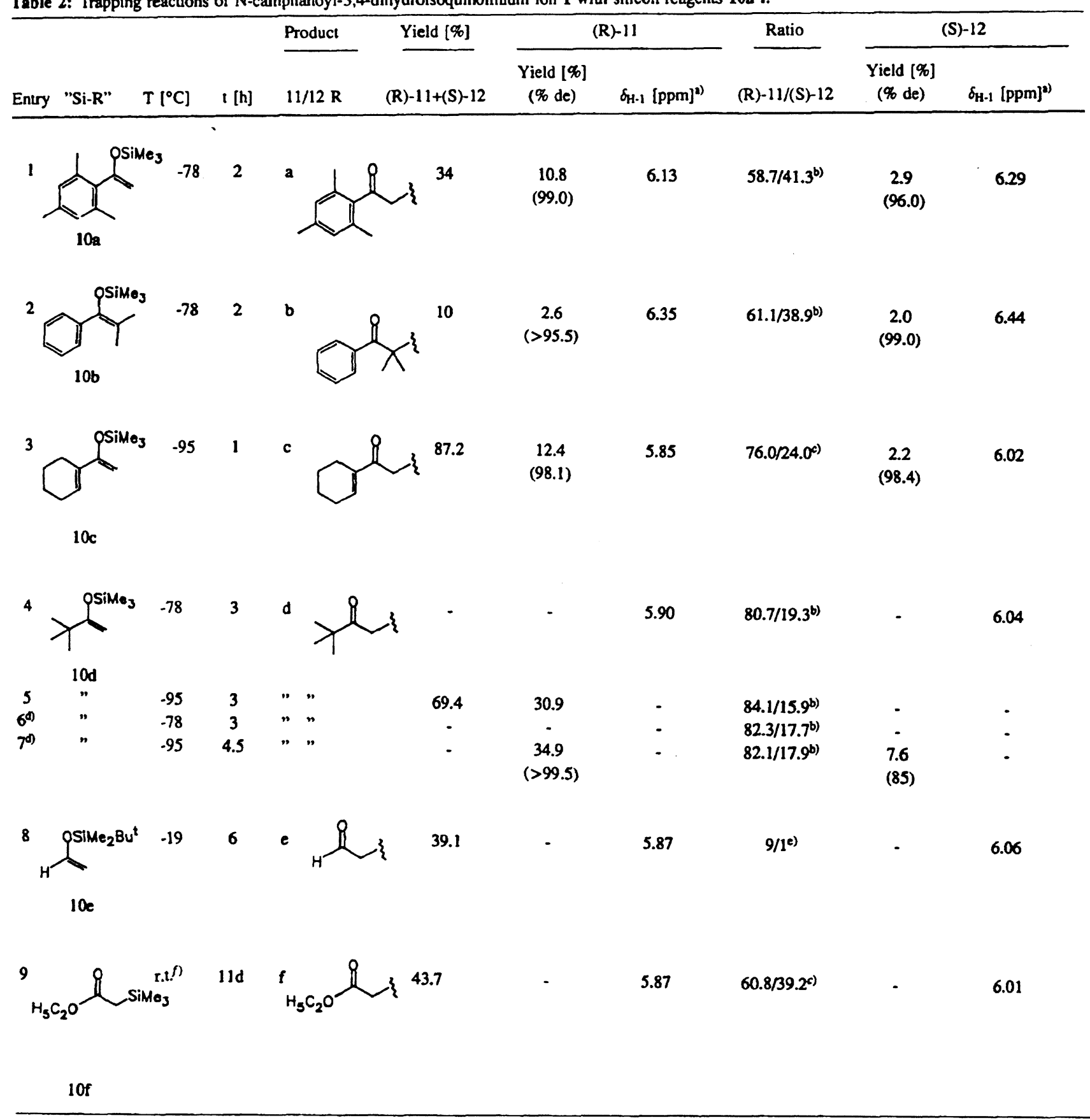

a) Signal of the major conformer recorded at $400 \mathrm{MHz}$.

b) Determined by $\mathrm{HPLC}$ on $\mathrm{SiO}_{2}$.

c) Determined by HPLC on a chiral stationary phase.

d) Addition of 1 equ. $\mathrm{TiCl}_{4}$ prior to $10 \mathrm{~d}$.

e) Determined by $400 \mathrm{MHz}$ - 'H-NMR; signals of atropisomers were assigned by spectra taken at different temperatures.

f) Room temperature. 
addition of 1.0 equiv. of $\mathrm{TiCl}_{4}$ the diastereoselectivity rose to $87.6 / 12.4$ (Table 1 entry 4 ).

As lowering the temp. to $-93^{\circ} \mathrm{C}$ (Table 1 entry 5) had no remarkable effect on the diastereoselectivity, the following experiments were carried out at $-78^{\circ} \mathrm{C}$. With increasing amounts of $\mathrm{TiCl}_{4}$ (in steps of 0.5 equiv.; after addition of 1.5 equiv. $\mathrm{TiCl}_{4}$ the reaction mixture became a suspension) the diastereoselectivity gradually rose (Table 1, entries 6 and 7) until at 2.5 equiv of $\mathrm{TiCl}_{4}$ the optimum (91.2/8.2 Table 1, entry 8) was reached (see also Table 1, entries 9 and 10). As evident from the experiment with 2.5 equiv. of $\mathrm{TiCl}_{4}$ (Table 1, entry 8), the price for the higher selectivity is a decrease in yield $(77.8 \%(\mathbf{R})-8 \mathbf{a}+(\mathbf{S})-9 \mathbf{a}$ after flash chromatography).

In order to get some information as to the reason for the stereoselectivity increasing effect of the Lewis acid, we treated a mixture of (R)-8a/(S)-9a of known composition (82.4/17.6) with 2.0 equiv. of $\mathrm{TiCl}_{4}$ for $2 \mathrm{~h}$ at $-78^{\circ} \mathrm{C}$. After that time the (R)-8a/(S)-9a ratio had changed only insignificantly (82.7/17.3). Therefore, it is assumed that the action of the Lewis acid results from its influence on the addition step and is not due to the conversion of already formed diastereomers.

The results of the bond forming reactions with silyl enol ether $7 b$ and $7 c$ were similar to those obtained with 7a (see Table 1, entry 11 to 13). For 7c (Table 1, entry 13) the influence of $\mathrm{TiCl}_{4}$ has not yet been investigated. Besides $7 \mathrm{a}-\mathrm{c}$ a variety of different silicon based nucleophiles has been employed in the addition reaction with the acyliminium ion 1. Results are summarized in Table 2 .

To our surprise silyl enol ethers 10a and 10b gave only very low diastereoselectivities (Table 2 , entries 1 and 2) despite the fact that they are sterically much more demanding than the silyl enol ethers 7a-c (Table 1). On the other hand, the steric hindrance led to a sharp drop in yield ((R)$11 \mathrm{a}+(\mathrm{S})-12 \mathrm{a},(\mathrm{R})-11 \mathrm{~b}+(\mathrm{S})-12 \mathrm{~b})$. The addition of silyl enol ether $10 \mathrm{c}$ derived from acetyl cyclohexene again proceeded smoothly, resulting after $1 \mathrm{~h}$ at $-95^{\circ} \mathrm{C}$ in a high conversion (according to TLC, the low yield of pure (R)-11c is due to incomplete separation) and a satisfactory diastereoselectivity (Table 2, entry 3). By employing silyl enol ether 10d a (R)-11d/(S)-12d ratio of 80.7/19.3 and 84.1/15.9, respectively, was achieved (Table 2, entries 4 and 5) as a function of the temp. of the reaction mixture. Addition of one equiv. of $\mathrm{TiCl}_{4}$ increased the ratio of the reaction at $-78^{\circ} \mathrm{C}$ (Table 2, entries 4 and 6 ), whereas the opposite was true for the experiment at $-95^{\circ} \mathrm{C}$ (Table 2, entries 5 and 7). At present we can not explain these results.

In the trapping reactions of 1 , enol ether 10e and even more so the silane $10 f$ proved to be of low reactivity, requiring higher reaction temp. (Table 2, entries 8 and 9). Probably at least in part due to this the diastereoselectivity in case of the addition of 10 was low (Table 2, entry 9).

The assignment of the absolute configuration of the newly produced stereogenic center to the major and minor diastereomers of the $\alpha$-amidoalkylation reaction as given in Table 2 requires some comment. This assignment is only tentative since it is merely based on a phenomenon observed with the 'H-NMR-chemical shift of the proton attached to the newly created stereogenic center. In the major isomers the proton at $\mathrm{C}-1$ of the isoquinoline nucleus in each case resonates at higher field than the one of the minor isomer (Table 2; only signals of the major conformers have been considered). The compounds listed in Table 1 behave exactly the same; however, for those compounds the (R)configuration of the major diastereomers has been established. Taking this into account, it is reasonable to assume that the major diastereomers of the $\alpha$-amidoalkylation products listed in Table 2 belong to the (R)-series as well.

\section{Structure Determination of N-Acyliminium Ion 1}

To verify the assumed structure of $\mathrm{N}$-acyliminium ion 1 , a single crystal $\mathrm{X}$-ray analysis at $-90^{\circ} \mathrm{C}$ was conducted. The experimental details ${ }^{15)}$ of the $X$-ray structural determination are summarized in Table 3; atomic fractional coordinates can be taken from Table 4 and selected bond distances are given in Table 5 .

Table 3: Experimental details of the $X$-ray structural determination of $\mathbf{1}^{16)}$

\begin{tabular}{|c|c|}
\hline Formula & {$\left[\mathrm{C}_{21} \mathrm{H}_{26} \mathrm{NO}_{5}\right]^{+} \mathrm{BF}_{4} \cdot 1 / 2 \mathrm{CH}_{2} \mathrm{Cl}_{2}$} \\
\hline Crystal system & monoclinic \\
\hline Space group & $P_{2}$ \\
\hline a [pm] & $947.0(7)$ \\
\hline b [pm] & $2269.9(9)$ \\
\hline c [pm] & $1164.3(5)$ \\
\hline$\beta\left[^{\circ}\right]$ & $111.79(5)$ \\
\hline$V\left[\mathrm{~nm}^{3}\right]$ & 2324 \\
\hline $\mathbf{Z}$ & $\begin{array}{l}4 \text { (two crystallographically independent } \\
\text { molecules) }\end{array}$ \\
\hline $\mathrm{d}$ calc $\left[\mathrm{g} \mathrm{cm}^{-3}\right]$ & 1.43 \\
\hline u $(\mathrm{Mo}-\mathrm{K} \alpha)\left[\mathrm{cm}^{-1}\right]$ & 2.25 \\
\hline Diffractometer & Nicolet P3 \\
\hline Temperature & $-90^{\circ} \mathrm{C}$ \\
\hline Scan mode & $\omega, \pm 1.2^{\circ}, 4 \leq \omega \leq 30^{\circ} \mathrm{min}^{-1}$ \\
\hline Measured refl. & $10496( \pm h \pm k \pm 1)$ \\
\hline Independent refi. & 7461 \\
\hline Observed reff. (I > $2 \sigma(\mathrm{I}))$ & 4703 \\
\hline No. of parameters & 281 \\
\hline $\mathbf{R}$ & 0.00771 \\
\hline $\mathbf{R}_{\mathbf{w}}$ & 0.00784 \\
\hline
\end{tabular}

Two crystallographically independent pairs of molecules of 1 beside two molecules of $\mathrm{CH}_{2} \mathrm{Cl}_{2}$ from the recrystallisation solvent are present in the unit cell. A side view of two of these molecules $\mathbf{A}$ and $\mathbf{B}$, one of each pair, is given in Figure ${ }^{15}{ }^{15}\left(\mathrm{BF}_{4}{ }^{-}\right.$-counter ion and $\mathrm{CH}_{2} \mathrm{Cl}_{2}$ are not shown).

From Figure 1 it is apparent that there is not a tremendous difference between molecules $\mathrm{A}$ and $\mathrm{B}$. The conformation of the $(\mathrm{C}=\mathrm{O})-(\mathrm{N}=\mathrm{C})$ - subunit is close to antiperiplanar, the torsion angles being $-176.1^{\circ}$ for $\mathrm{A}(\mathrm{C} 11-\mathrm{N} 1-\mathrm{C} 10-03)$ and $-169.8^{\circ}$ for $B(C 32-N 2-C 31-08)$ and this is among the most interesting findings. The carbonyl group is almost eclipsed with the bridging carbon (e.g. C-4 in A) of the camphanic 
Table 4: Atomic fractional coordinates $\left(x 10^{4}\right)$ and equivalent isotropic thermal parameters $\left(\mathrm{pm}^{-2} \times 10^{-1}\right)$ for 1

\begin{tabular}{|c|c|c|c|c|}
\hline & $\mathbf{x}$ & y & $z$ & U \\
\hline$c(1)$ & $-151(9)$ & $3772(4)$ & $2693(7)$ & $23(2)$ \\
\hline$c(2)$ & $-2679(77)$ & $3644(29)$ & $1656(59)$ & $27(17)$ \\
\hline$c(3)$ & $-2192(8)$ & $3517(3)$ & $3082(7)$ & $28(2)$ \\
\hline$c(4)$ & $-598(8)$ & $3238(3)$ & $3314(7)$ & $29(2)$ \\
\hline$c(5)$ & $-687(80)$ & $2629(33)$ & $2663(63)$ & $48(18)$ \\
\hline$c(6)$ & $392(11)$ & $3244(5)$ & $4668(8)$ & $49(3)$ \\
\hline$c(7)$ & $-3323(10)$ & $3181(4)$ & $3472(8)$ & $40(2)$ \\
\hline$c(8)$ & $-1770(10)$ & $4131(4)$ & $3649(8)$ & $40(2)$ \\
\hline$c(9)$ & $-358(76)$ & $4292(29)$ & $3456(61)$ & $26(17)$ \\
\hline$c(10)$ & $1304(9)$ & $3725(3)$ & $2444(7)$ & $29(2)$ \\
\hline$c(11)$ & $722(10)$ & $4582(4)$ & $1072(7)$ & $28(2)$ \\
\hline$c(12)$ & $1142(9)$ & $5010(3)$ & $383(7)$ & $29(2)$ \\
\hline$c(13)$ & $28(33)$ & $5409(12)$ & $-358(23)$ & $24(7)$ \\
\hline$c(14)$ & $454(10)$ & $5840(4)$ & $-1004(7)$ & $29(2)$ \\
\hline$c(15)$ & $1986(9)$ & $5871\langle 3\}$ & $-923(7)$ & $32(2)$ \\
\hline$c(16)$ & $3065(9)$ & $5469(3)$ & $-192(7)$ & $30(2)$ \\
\hline$c(17)$ & $2664(8)$ & $5047(3)$ & $450(6)$ & $27(2)$ \\
\hline$C(18)$ & $3777(10)$ & $4616(4)$ & $1305(8)$ & $32(2)$ \\
\hline$C(19)$ & $3032(10)$ & $4041(4)$ & $1355(8)$ & $33(2)$ \\
\hline$c(20)$ & $-2039(10)$ & $6264(4)$ & $-1755(8)$ & $45(2)$ \\
\hline$c(21)$ & $3834(11)$ & $6347(5)$ & $-1577(9)$ & $56(3)$ \\
\hline $0(1)$ & $-3946(23)$ & $3613(9)$ & $907(18)$ & $40(6)$ \\
\hline $0(2)$ & $-1419(6)$ & $3797(2)$ & $1475(4)$ & $25(1)$ \\
\hline$O(3)$ & $2281(23)$ & $3350(9)$ & $2949(18)$ & $39(5)$ \\
\hline $0(4)$ & $-524(7)$ & $6255(3)$ & $-1766(5)$ & $38(2)$ \\
\hline $0(5)$ & $2264(6)$ & $6302(2)$ & $-1611(5)$ & $42(1)$ \\
\hline$N(1)$ & $1627(24)$ & $4134(9)$ & $1627(18)$ & $28(5)$ \\
\hline$c(22)$ & $-4412(9)$ & $6526(4)$ & $3886(7)$ & $26(2)$ \\
\hline$c(23)$ & $-6027(11)$ & $6668(4)$ & $4880(8)$ & $37(2)$ \\
\hline$c(24)$ & $-6769(11)$ & $6827(4)$ & $3540(8)$ & $36(2)$ \\
\hline$c(25)$ & $-5324(8)$ & $7083(3)$ & $3368(7)$ & $28(2)$ \\
\hline$c(26)$ & $-4705(11)$ & $7637(4)$ & $4124(8)$ & $47(3)$ \\
\hline$C(27)$ & $-5587(25)$ & $7218(10)$ & $1985(18)$ & $38(6)$ \\
\hline$C(28)$ & $-8149(10)$ & $7216(4)$ & $3235(8)$ & $52(2)$ \\
\hline$c(29)$ & $-7017(25)$ & $6229(9)$ & $2851(20)$ & $35(5)$ \\
\hline$c(30)$ & $-5366(22)$ & $6030(9)$ & $3071(18\}$ & $33(5)$ \\
\hline$c(31)$ & $-2707(23)$ & $6546(9)$ & $4141(17)$ & $29(5)$ \\
\hline$c(32)$ & $-2078(9)$ & $5648(3)$ & $5431(7)$ & $31(2)$ \\
\hline$c(33)$ & $-1043(22)$ & $5227(9)$ & $6109(18)$ & $33(5)$ \\
\hline$c(34)$ & $-1497(23)$ & $4780(8)$ & $6789(16)$ & $28(5)$ \\
\hline$c(35)$ & $-479(10)$ & $4371(4)$ & $7451(8)$ & $36(2)$ \\
\hline$c(36)$ & $1018(24)$ & $4365(10)$ & $7428(19)$ & $40(5)$ \\
\hline$c(37)$ & $1441(16)$ & $4775(5)$ & $6736(11)$ & $33(3)$ \\
\hline$c(38)$ & $456(14)$ & $5221(6)$ & $6106(11)$ & $27(3)$ \\
\hline$c(39)$ & $821(10)$ & $5658(4)$ & $5300(7)$ & $31(2)$ \\
\hline$c(40)$ & $-37(15)$ & $6226(6)$ & $5246(12)$ & $30(3)$ \\
\hline$c(41)$ & $3481(16)$ & $3898(7)$ & $8138(13)$ & $50(4)$ \\
\hline$c(42)$ & $-2262(11)$ & $3942(5)$ & $8231(9)$ & $50(3)$ \\
\hline $0(6)$ & $-6483(10)$ & $6679(4)$ & $5714(8)$ & $41(2)$ \\
\hline $0(7)$ & $-4588(9)$ & $6461(4)$ & $5089(7)$ & $30(2)$ \\
\hline $0(8)$ & $-2204(10)$ & $6906(4)$ & $3628(8)$ & $40(2)$ \\
\hline $0(9)$ & $-756(7)$ & $3941(3)$ & $8160(5)$ & $41(2)$ \\
\hline $0(10)$ & $1923(10)$ & $3933(4)$ & $8088(8)$ & $40(2)$ \\
\hline$N(2)$ & $-1662(8)$ & $6129(3)$ & $4938(6)$ & $29(2)$ \\
\hline$B(1) \bullet 1$ & $2308(4)$ & $665(2)$ & $8424(3)$ & $40(3)$ \\
\hline$F(1) \cdot)$ & $3171(4)$ & $1146(1)$ & $8986(3)$ & $76(2)$ \\
\hline$F(2) \bullet)$ & $2647(4)$ & $502(2)$ & $7418(3)$ & $57(1)$ \\
\hline$F(3) \bullet)$ & $2625(4)$ & 205 (1) & $9251(3)$ & $64(2)$ \\
\hline$E(4) \bullet 1$ & $791(3)$ & $806(2)$ & $8043(3)$ & $80(2)$ \\
\hline$B(2) \bullet)$ & $4267(1)$ & $4661(1)$ & $4990(1)$ & $31(2)$ \\
\hline$F(5) \cdot 1$ & $2973(1)$ & $4840(1)$ & $4075(1)$ & $71(2)$ \\
\hline$F(6) \bullet)$ & $5359(2)$ & $4566(2)$ & $4519(2)$ & $66(2)$ \\
\hline$E(7) \bullet 1$ & $4742(3)$ & $5082(1)$ & $5875(2)$ & $75(2)$ \\
\hline$F(8) \cdot 1$ & $3999(2)$ & $4155(1)$ & $5492(3)$ & $88(2)$ \\
\hline $\operatorname{cl}(1) \cdots$ & $3520(3)$ & $2587(1)$ & $198(2)$ & $57(1)=)$ \\
\hline$C I(2) \cdots$ & $389(3)$ & $2573(2)$ & $29(2)$ & $\left.69(1)^{0}\right)$ \\
\hline$C(43) \cdots$ & $1614(10)$ & $2487(5)$ & $-800(8)$ & $47(3)$ \\
\hline
\end{tabular}

a) Atomic coordinates of $\mathrm{BF}^{4}$.

b) Atomic coordinates of $\mathrm{CH}_{2} \mathrm{Cl}_{2}$.

c) Equivalent isotropic $U$ defined as one third of the trace of the orthogonalized $U_{i j}$ tensor.

acid residue (see Figure 2, front view on $\mathbf{A}$ ), and the carbon of the iminium subunit (e.g. C-11) is situated on the sterically less demanding face of the chiral auxiliary center, e.g. for $A$ between $0-2$ and $C-9$.

This raises the question whether the asymmetric induction we had observed in our $\alpha$-amidoalkylation reactions possibly originates from the above or from a related conformation, with $0-2$ and C-9 discriminating the two
Table 5: Selected bond distances (pm) of 1

\begin{tabular}{|c|c|c|c|}
\hline $\begin{array}{l}C(1)-C(4) \\
C(1)-C(10) \\
C(2)-C(3) \\
C(2)-O(2) \\
C(3)-C(7) \\
C(4)-C(5) \\
C(8)-C(9) \\
C(10)-N(1) \\
C(11)-N(1) \\
C(12)-C(17) \\
C(14)-C(15) \\
C(15)-C(16) \\
C(16)-C(17) \\
C(18)-C(19) \\
C(20)-O(4) \\
C(22)-C(25) \\
C(22)-C(31) \\
C(23)-C(24) \\
C(23)-O(7) \\
C(24)-C(28) \\
C(25)-C(26) \\
C(29)-C(30) \\
C(31)-N(2) \\
C(32)-N(2) \\
C(33)-C(38) \\
C(35)-C(36) \\
C(36)-C(37) \\
C(37)-C(38) \\
C(39)-C(40) \\
C(41)-O(10) \\
B(1)-F(1) \\
B(1)-F(3) \\
B(2)-F(5) \\
B(2)-F(7) \\
C I(1)-C(43)\end{array}$ & $\begin{array}{l}154.8(12) \\
151.4(13) \\
157.6(66) \\
133.2(79) \\
151.5(13) \\
156.4(76) \\
148.1(80) \\
144.0(25) \\
133.4(21) \\
141.7(12) \\
142.1(13) \\
139.8(10) \\
135.3(12) \\
149.7(12) \\
143.9(12) \\
152.4(11) \\
153.1(23) \\
149.8(12) \\
137.5(13) \\
150.6(13) \\
152.2(12) \\
155.5(31) \\
143.4(19) \\
135.8(11) \\
142.1(27) \\
142.8(26) \\
138.4(28) \\
138.7(17) \\
151.4(16) \\
145.6(19) \\
137.5(5) \\
137.5(5) \\
135.4(2) \\
135.5(2) \\
176.1(9)\end{array}$ & $\begin{array}{l}C(1)-C(9) \\
C(1)-O(2) \\
C(2)-O(1) \\
C(3)-C(4) \\
C(3)-C(8) \\
C(4)-C(6) \\
C(10)-O(3) \\
C(11)-C(12) \\
C(12)-C(13) \\
C(13)-C(14) \\
C(14)-O(4) \\
C(15)-O(5) \\
C(17)-C(18) \\
C(19)-N(1) \\
C(21)-O(5) \\
C(22)-C(30) \\
C(22)-O(7) \\
C(23)-O(6) \\
C(24)-C(25) \\
C(24)-C(29) \\
C(25)-C(27) \\
C(31)-O(8) \\
C(32)-C(33) \\
C(33)-C(34) \\
C(34)-C(35) \\
C(35)-O(9) \\
C(36)-O(10) \\
C(38)-C(39) \\
C(40)-N(2) \\
C(42)-O(9) \\
B(1)-F(2) \\
B(1)-F(4) \\
B(2)-E(6) \\
B(2)-E(8) \\
C 1(2)-C(43)\end{array}$ & $\begin{array}{l}153.4(72) \\
148.0(8) \\
119.6(60) \\
156.6(11) \\
153.0(12 \\
152.1(11) \\
123.4(21) \\
140.8(12) \\
141.4(27) \\
138.2(32) \\
138.6(9) \\
134.9(10) \\
150.9(10) \\
149.3(27) \\
147.6(13) \\
153.1(20) \\
147.8(13) \\
120.0(15) \\
156.7(14) \\
154.9(23) \\
156.6(23) \\
120.7(25) \\
138.6(20) \\
144.8(30) \\
135.3(20) \\
136.6(12) \\
134.1(22) \\
149.2(17) \\
146.2(15) \\
145.9(13) \\
137.5(5) \\
137.5(5) \\
135.5(3) \\
135.4(3) \\
177.4(12)\end{array}$ \\
\hline
\end{tabular}

faces of the iminium subunit. However, the conformational preference in a crystal lattice can be distinctly different from that in solution. We expected ${ }^{1} \mathrm{H}-\mathrm{NMR}$-spectroscopy, including NOEDS, to provide some information regarding the preferred conformation of 1 in solution.

First, conventional ' $\mathrm{H}$-NMR-spectra of 1 in $\mathrm{CD}_{2} \mathrm{Cl}_{2}$ and $\mathrm{CDCl}_{3}$ at room temp. were taken. The ${ }^{1} \mathrm{H}-\mathrm{NMR}$-spectra unfortunately showed not only the signals of 1 but also the signals of an unidentified compound present in minor amounts. The intensities of the signals arising from the unknown compound varied from sample to sample and also increased upon standing at room temp. (in a capped NMR tube). Therefore, in our opinion that compound results from the addition of $\mathrm{H}_{2} \mathrm{O}$ to the iminium ion 1 , although we did our best to exclude moisture. The ${ }^{1} \mathrm{H}-\mathrm{NMR}$ data for 1 were as expected (e.g.: 9.41 ppm, s, H-1; 7.51 ppm, s, H-8; 2.65 ppm, ddd, H-6'ax; 2.55 $\mathrm{ppm}$, ddd, H-6' 'eq; the assignment is based on a combination of NOEDS and coupling constants) and did not change significantly upon cooling to $-60^{\circ} \mathrm{C}\left(\mathrm{CDCl}_{3}\right)$ and $-90^{\circ} \mathrm{C}\left(\mathrm{CD}_{2} \mathrm{Cl}_{2}\right)$, respectively.

NOEDS experiments revealed that the axially positioned proton at $C-6^{\circ}$ (H-6'ax) gives rise to the signal at $2.65 \mathrm{ppm}$. Irradiation of the methyl groups of the camphanic acid moiety led to an enhancement of the signals at $1.85,1.98$, and $2.55 \mathrm{ppm}$ but did not change the intensity of the signal at $2.65 \mathrm{ppm}$. By NOEDS experiments it was further found that irradiation of the proton attached to the iminium subunit $(\mathrm{H}-1)$ enhances both the signals of $\mathrm{H}^{\prime} 6^{\prime} \mathrm{ax}(\delta=2.65 \mathrm{ppm})$ and $\mathrm{H}-8$, and that, conversely, irradiation of $\mathrm{H}$ 6 'ax results in a clear enhancement of the signal of $\mathrm{H}-1$ whereas the proton at $\mathrm{C}-3$ of the isoquinoline ring remains unaffected.

Therefore, we now assume that in $\mathrm{CDCl}_{3}$ solution a conformation similiar to that observed in the crystal lattice is the prevailing one.

A stereomodel that accounts for the observed asymmetric induction (Table 1) is proposed as given in Figure 4, wherein the $\mathrm{CH}_{2}$-group facing the oxygen brings forth the stereadifferentiation ${ }^{17}$. In an analogous system with the 

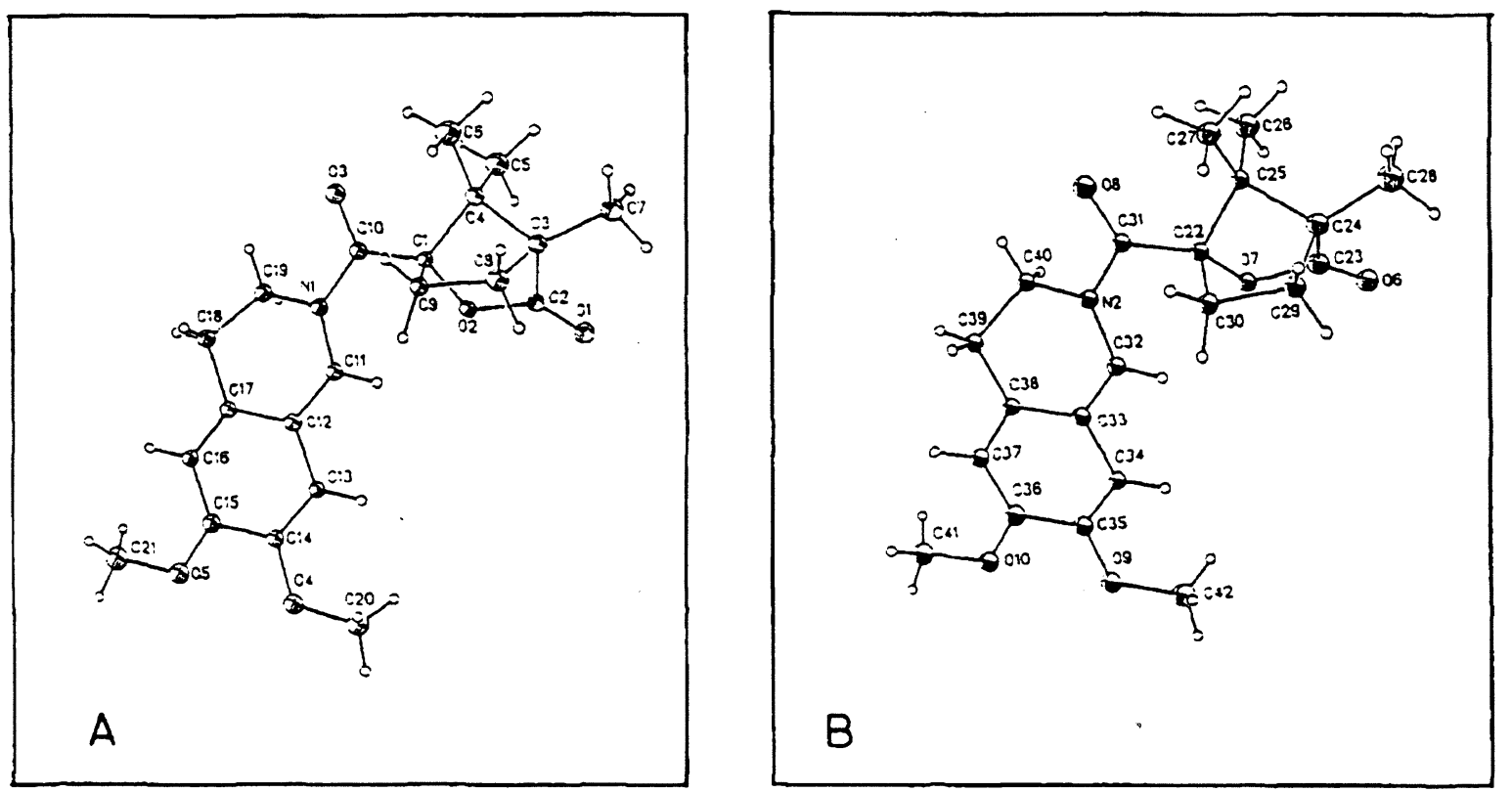

Figure 1: Perspective side view of molecules A and B of 1 (arbitrary atomic numbering, 20\% probability of finding).

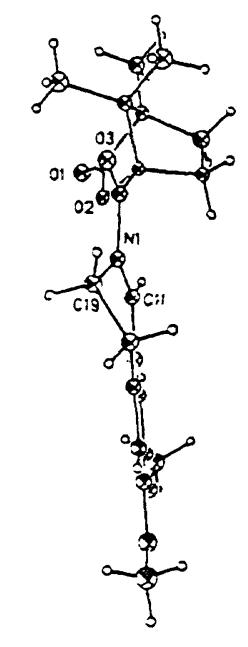

A

Figure 2: Perspective front view of molecule A of 1 (arbitrary atomic numbering, $20 \%$ probability of finding).

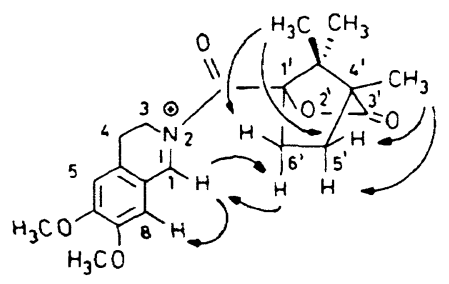

Figure 3: Nuclear Overthauser effects observed for 1

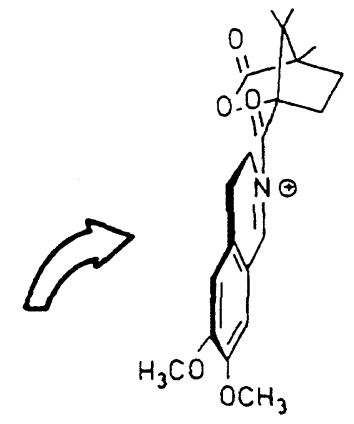

Figure 4: Stereomodel

isoquinoline ring replaced by a tetrahydropyridine moiety we have found the opposite direction of asymmetric induction $^{18)}$ when the reaction was performed with Lewis acids like $\mathrm{SnCl}_{4}$ or $\mathrm{TiCl}_{4}$. This is not in conflict with the model presented here, if one assumes that in those cases the Lewis acid (after taking up the leaving group $\mathrm{Cl}^{-} \rightarrow$ e.g. $\mathrm{TiCl}_{5}{ }^{-}$or $\mathrm{SnCl}_{5}{ }^{-}$) shields the front face of the piperidine ring by forming a complex with the O-CO-bridge (This has already been proposed by us as a rationale for the asymmetric induction observed for the piperdine system ${ }^{8}$ ). In 1 the counterion $\mathrm{BF}_{4}^{-}$already has its maximum coordination number (in the piperidine system the $\mathrm{BF}_{3} \mathrm{Cl}^{-}$and $\mathrm{SbCl}_{6}{ }^{-}$counterions caused a low but also reversed asymmetric induction ${ }^{18)}$ - as compared to $\mathrm{TiCl}_{5}{ }^{-}$or $\mathrm{SnCl}^{5}$ - that equals the one observed for 1 ). Furthermore the iminium ion 1, in contrast to that piperidine system, also has two methoxy groups available for the complexation of a Lewis acid. 
1-(2-Phenylethyl)isoquinolines from Asymmetric $\alpha$-Amidoalkylation Products

The mixtures of diastereomers (R)-8/(S)-9a-c obtained by the AE $\alpha A$ procedure after flash chromatography were employed in the synthesis of 1-substituted tetrahydroisoquinolines (R)-16a-c including the alkaloid homolaudanosine (R)-18, as described below. By hydrogenation in acetic acid $/ 1 \%$ trifluoroacetic acid using $\mathrm{Pd} / \mathrm{C}(10 \% \mathrm{Pd})$ the amides (R)-13/(S)-14a-c were formed.

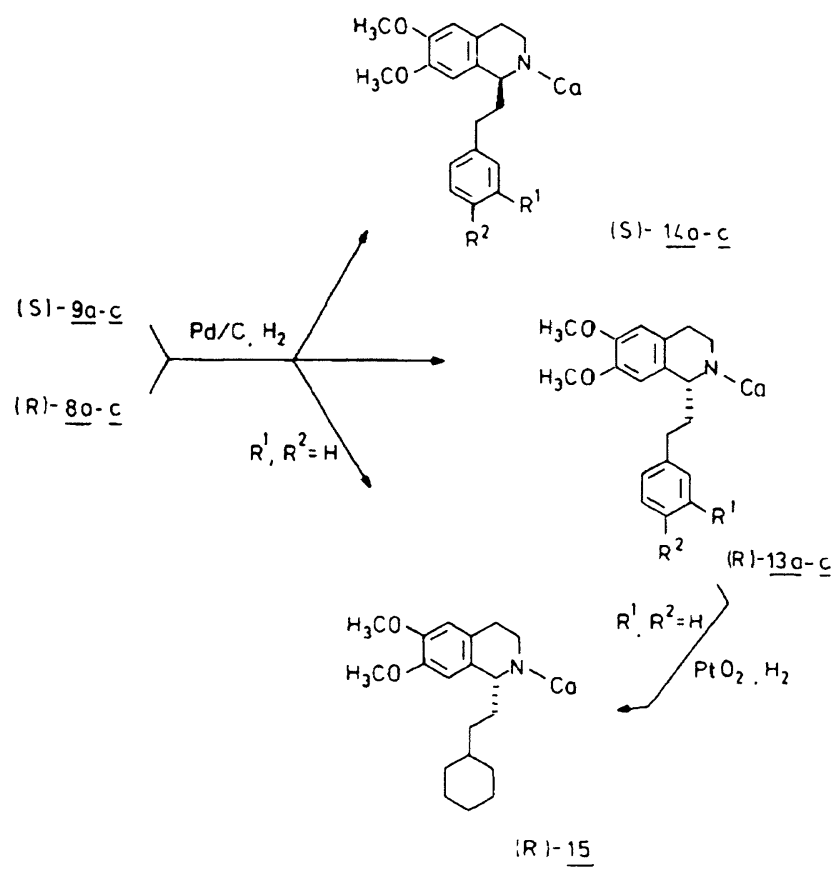

In contrast to the starting ketones, these diastereomers proved to be separable on silica gel. The yields of the major ((R)-13) and minor diastereomers $((S)-14)$ are listed in Table 6. As a result of overreduction in the case of the hydrogenation of $(R)-13 a /(S)-14 a$ the cyclohexyl derivative (R)-15 (7\%) was isolated. The (R)-configuration of (R)-15 has been established by hydrogenation of the pure diastereomer (R)-13a, which by use of $\mathrm{PtO}_{2}$ as catalyst yielded (R)15 as well. Beside (R)-15 no other cyclohexane derivatives have been isolated from the above mentioned hydrogenation reactions (of the diastereomeric mixtures), though it is our feeling that such derivatives might have been formed. The ratio of the diastereomers (R)-13/(S)-14a-c was found to be almost the same as the ratio for $(\mathrm{R})-8 /(\mathrm{S})-9 \mathrm{a}-\mathrm{c}$ (Table 6 ), except for the compounds with a 4-chlorophenyl substituent (Table 6, entry 2). This might be due to a difference in the rate of a side reaction that occured during the hydrogenation of $(R)-8 b /(S)-9 b$. In addition to the carbonyl oxygen also the chlorine substituent had been eliminated to some extent (36\%), and (R)-13a/(S)-14a were formed as side products. This side reaction also complicated the isolation of the chloro compound (R)-13b in pure form.

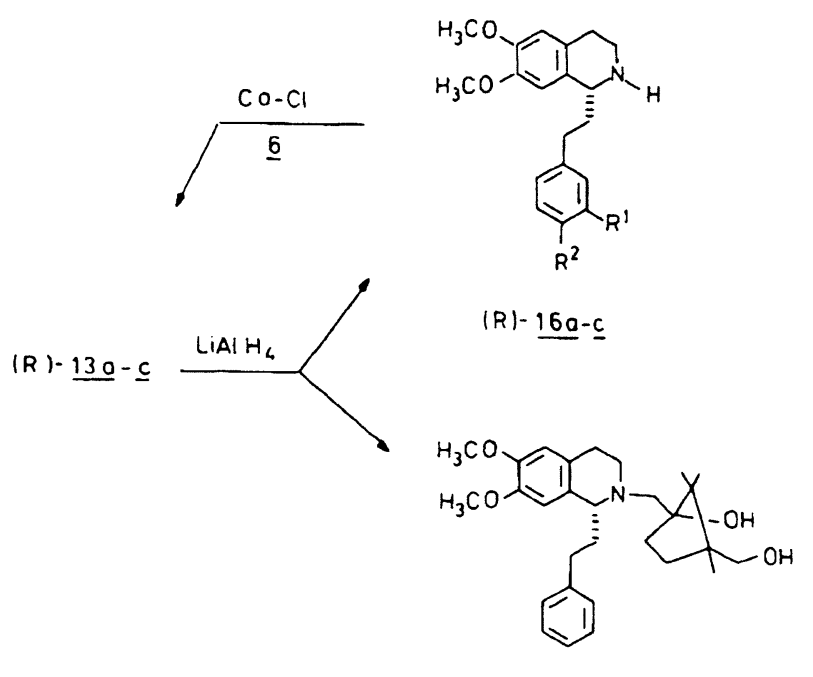

(R) $\underline{17}$

$$
\text { (S) } 130 \stackrel{\mathrm{LACH}}{\longrightarrow} \text { (S) } 1 \text {-160 }
$$

The next step involved the removal of the chiral auxiliary and was first attempted by means of $\mathrm{LiOH}$ in dioxane/ $/ \mathrm{H}_{2} \mathrm{O}$ $\left(3 / 1\right.$, sealed tube, $\left.\sim 150^{\circ} \mathrm{C}\right)$, although without any noticeable success. Finally we found that amides (R)-13a-c, as also demonstrated in a single case ((S)-13a) for the (S)-series, can be cleaved by treatment with $2.5-5.0 \mathrm{~mol}$. - equiv. of $\mathrm{LiAlH}_{4}$ in THF (2-3 h, room temp.). The pure amines (R)$16 a-c$ and (S)-16a were thus obtained in fairly good yields after flash chromatography (see Table 7).

Table 6: Compounds (R)-13a-c/(S)-14a-c from hydrogenation of (R)-8a-c/(S)-9a-c

\begin{tabular}{|c|c|c|c|c|c|c|c|c|}
\hline \multirow[b]{2}{*}{ Entry } & \multicolumn{2}{|c|}{ Substituents } & \multicolumn{2}{|c|}{ Ratio } & \multicolumn{2}{|c|}{ (R) -13} & \multicolumn{2}{|c|}{ (S) -14} \\
\hline & $\mathbf{R}^{1}$ & $\mathrm{R}^{2}$ & $(R)-8 /(S)-9$ & $(R)-13 /(S)-14$ & Yield $[\%]^{2)}$ & {$[\alpha]_{578}$} & Yield [\%] & {$[\alpha]_{578}$} \\
\hline 1 & a $\mathrm{H}$ & $\mathrm{H}$ & $82.4 / 17.6$ & $83.3 / 16.7$ & 59.1 & $-119.6^{\circ}$ & 8.7 & $+121.2^{\circ}$ \\
\hline 2 & b H & $\mathrm{Cl}$ & $85.2 / 14.8$ & $90.1 / 9.9$ & $\begin{array}{r}5.3^{b)} \\
51.9^{c)}\end{array}$ & $-102.9^{\circ}$ & - & - \\
\hline 3 & $\mathrm{c} \mathrm{OCH}_{3}$ & $\mathrm{OCH}_{3}$ & $82.4 / 17.6$ & $81.5 / 18.5$ & 37.9 & $-83.0^{\circ}$ & - & - \\
\hline
\end{tabular}

a) Pure compound according to HPLC.

b) Pure compound for analytical purposes only.

c) Hard to separate mixture of (R)-13a and (R)-13b 
Table 7: Sccondary amines (R)-16a-c and (S)-16a

\begin{tabular}{|c|c|c|c|c|c|c|}
\hline \multicolumn{2}{|r|}{ Start. Comp. } & \multicolumn{2}{|c|}{ Substituents } & \multicolumn{3}{|c|}{ Product } \\
\hline Entry & No. & $R^{\prime}$ & $R^{2}$ & No. & Yield [\%] & {$[\alpha]_{578}$} \\
\hline 1 & (R)-13a & $\mathrm{H}$ & $\mathrm{H}$ & (R)-16a & 64.7 & +25.5 \\
\hline 2 & (S)-14a & $"$ & $"$ & (S)-16a & 63.0 & -22.0 \\
\hline 3 & (R)-13b') & $\mathrm{H}$ & $\mathrm{Cl}$ & (R)-16b & $16.1^{b)}$ & +12.4 \\
\hline 4 & (R)-13c & $\mathrm{OCH}_{3}$ & $\mathrm{OCH}_{3}$ & (R)-16c & 77.0 & +15.1 \\
\hline
\end{tabular}

a) Contaminated with $\sim 36 \%$ (R)-13a.

b) Contamination of starting material has not been taken into account.

This cleavage procedure is not completely devoid of side reactions. When applied to $(R)-13 a$ besides the secondary amine (R)-16a also the tertiary amine (R)-17 was isolated (30.4\%). It must be assumed that similar by-products have formed from (R)-13b and (R)-13c as well, although we could not isolate them. The lower yield of (R)-16b can be blamed on the fact that for convenience a mixture of (R)$13 b$ and $(R)-13 a$ (obtained from hydrogenation, vide supra) had been employed as starting material. (R)-16b is an optically active derivative of the analgesic drug methopholine II $^{3)}$, mentioned in the introduction (methopholine I stands for the racemic compound). Its R-stereochemistry has been established by comparing the optical rotation $\left([\alpha]_{578}=\right.$ $\left.+12.4^{\circ},[\alpha]_{546}=+11.5^{\circ}\right)$ with lit. values ${ }^{19)}$ reported for authentic sample $\left((R)-16 b:[\alpha]_{D}=+15^{\circ}\right)$ which had been prepared from a precursor obtained by optical resolution. The $R$ configuration of $R-16 a$ could be deduced from the product distribution that was observed after hydrogenation of $(R)-8 b /(S)-9 b$. Thereby, in addition to $(R)-13 b /(S)-14 b, a$ mixture of (R)-13a/(S)-14a was formed (vide supra) wherein the predominant isomer was the same as in the product obtained directly from (R)-8a/(S)-9a, as verified by HPLC.

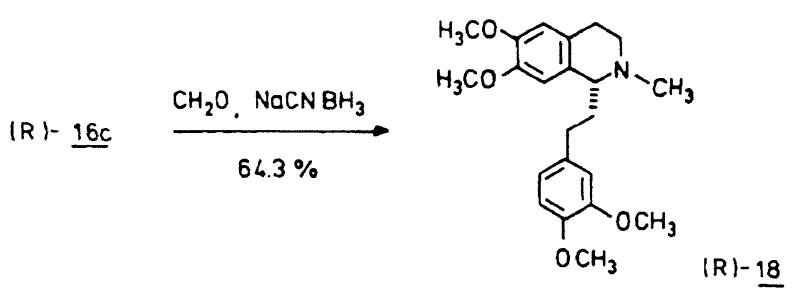

1-1-Homolaudanosine

To complete the synthesis of (R)-homolaudanosine ((R)18), (R)-16c was subjected to reductive $\mathrm{N}$-methylation with $\mathrm{CH}_{2} \mathrm{O} / \mathrm{NaCNBH}_{3}$ which, after aqueous work-up and flash chromatography, afforded (R)-18 in $64.3 \%$ yield.

The optical rotation of the obtained product $\left([\alpha]_{578}=-\right.$ $\left.13.5^{\circ}, \mathrm{EtOH}\right)$, compared to that of the natural enantiomer ${ }^{5}$ $\left((S):[\alpha]_{D}=+11^{\circ}, E t O H\right)$, indicated that our synthesis had resulted in (R)-homolaudanosine. Of course, also the stereochemistry of the precursors - including the $\alpha$-amidoalkylation products - has been established herewith.

In order to determine the optical purity of the obtained secondary amines, a sample of (R)-16a was reconverted into the starting amide by treating it with (-)-camphanic acid chloride (6). HPLC revealed (R)-13a to be the prevailing compound, accompanied by trace amounts of a side product (<0.4\%) which possibly was (S)-14a. Therefore, the optical purity of the amines described herein ((R)-16a-c, (S)-16a and (R)-18) should be higher than at least $99 \%$ (ee).

\section{A Chiral Carbamate Derived Acyliminium Ion}

As a logical extension of our work with chiral $\mathrm{N}$-acyliminium ions derived from amides, we have studied the applicability of our concept to carbamate 20 . The synthesis of 20, starting from the isoquinoline 5 and the chiral chloroformate 19, was routine (yield 94.0\%). When treated with $\mathrm{Ph}_{3} \mathrm{C}^{+} \mathrm{BF}_{4}$, carbamate 20 was completely consumed within $16 \mathrm{~h}$ (TLC) and from the subsequent reaction with silyl enol ether $7 \mathbf{a}$ (at $-78^{\circ} \mathrm{C}$ ) which yielded (R)-22 and (S)-23 it became evident that the acyliminium ion 21 had formed.

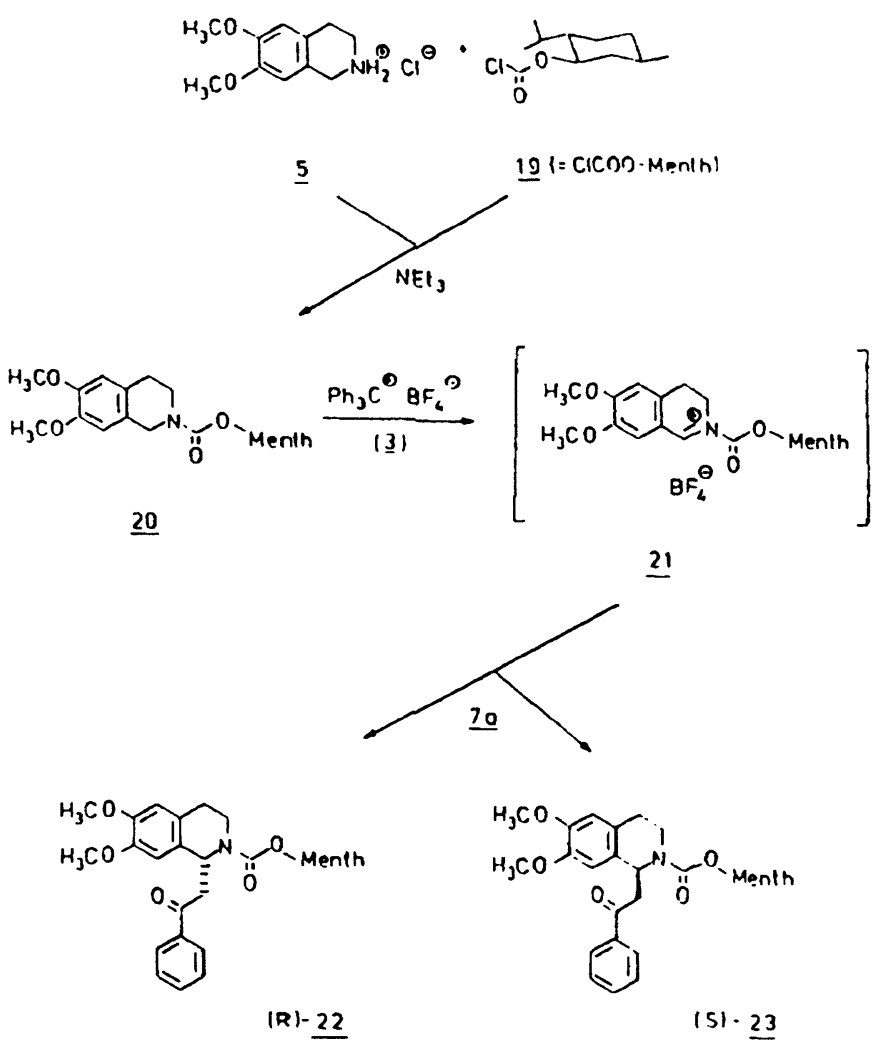

The diastereomers (R)-22 and (S)-23 were isolated in a combined yield of $78 \%$ by flash chromatography wherein they proved inseparable on silica gel. HPLC analysis with a chiral stationary phase revealed that the reaction had more or less been devoid of asymmetric induction ((R)-22/(S)-23 1/1). Therefore, this synthetic sequence appeared unattractive to us and consequently has not been carried on further.

In summary, we have demonstrated that tetrahydroisoquinoline amide 4 can efficiently be oxidized with triphenylcarbenium tetrafluoroborate (3), yielding acyliminium ion 1. Subsequent trapping reactions with silyl nucleophiles proceed with stereoselective bond formation, the resulting addition products being usefull intermediates in the 
synthesis of chiral 1-substituted amines of high enantiomeric purity. By means of X-ray and ${ }^{1} \mathrm{H}-\mathrm{NMR}$ studies light has been shed upon the conformational preference of acyliminium ion 1. Currently we are engaged in the synthesis of isoquinoline derived 1,3-amino alcohols by applying the asymmetric $\alpha$-amidoalkylation methodology presented herein.

We are greatly indebted to Prof. F. Eiden for his generous support and to Prof. W. Beck for providing the X-ray facilities. We thank Dr. $H$. Lerche for carrying out the NOE-experiments and Mr.M. Steimann for his help in performing the $\mathrm{X}$-ray analysis.

Financial support of this work by Deutsche Forschungsgemeinschaft and Fonds der Chemischen Industrie is gratefully acknowledged.

\section{Experimental Part}

\section{General procedures}

Standard vacuum techniques were used in the handling of air sensitive materials. - Solvents were dried and kept under $\mathrm{N}_{2}$ and freshly distilled before use. - Melting points are uncorrected: melting point apparatus according to Dr. Totolli. - 'H-NMR spectra: 400 JNM-GX (Jeol), chemical shifts (ס). TMS as internal reference. - Mass spectra: $\mathrm{CH} 7$ (Varian). - IR spectra: Acculab 6 (Beckman) and model 710B (Perkin Elmer). Liquids were run as films, solids as $\mathrm{KBr}$ pellets. - Optical rotation: Light electric polarimeter Zeiss, $0.5 \mathrm{dm}$ cell. - Combustion analysis: CHN Rapid (Heraeus). - Column chromatography: Flash Chromatography. - Radial chromatography: Chromatotron (Harrison Research), Si 60. - HPLC: L-6000 pump (Merck Hitachi), UV-Detektor 440, $254 \mathrm{~nm}$ (Waters), Refractive Index Detector RID6A (Shimadzu), Chromato-Integrator D-2000 (Merck Hitachi); Achiral column: LiChroCart ${ }^{R}$, LiChroSort ${ }^{R}$ Si60 cartridge ( $250 \mathrm{~mm} \times 4 \mathrm{~mm}$, Merck); precolumn: LiChroCart ${ }^{R}$, LiChroSorb ${ }^{R}$ Si60 precolumn canridge $(25 \times 4$ $\mathrm{mm}$, Merck). Chiral column: (R)-N.3,5-Dinitrobenzoylphenylglycin covalently bound ( $250 \times 4 \mathrm{~mm}$. Bakerbond ${ }^{R}$ DNBPG, J.T. Baker Chemicals); precolumn: see above achiral column. Prep. HPLC: HPLC pump 64 (Knauer, prep. head), spectrophotometric detector 8201 (Bischoff), integrator Datamodule (Waters); Achiral column: LiChroSorb ${ }^{R}$ Si60 $7 \mu$

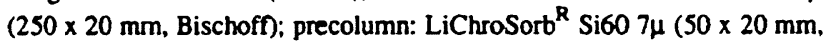
Bischoff). Chiral column: (R)-N-3,5-Dinitrobenzoylphenylglycin covalently bound $(250 \times 22 \mathrm{~mm}$, Chiral=Sil00D-DNB Phgly, $5 \mu$ Serva).

6,7-Dimethoxy-2-[(1S, 4R)-4,7,7-trimethyl-3-oxo-2-oxa-1-bicyclo[2.2.1]heprylcarbonyl]-3,4-dihydroisoquinolinium-tetrafluoroborate (1)

To a stirred solution of $0.530 \mathrm{~g}(1.606 \mathrm{mmol})$ of 3 in $5 \mathrm{ml}$ of $\mathrm{CH}_{2} \mathrm{Cl}_{2}$ $0.500 \mathrm{~g}(1.339 \mathrm{mmol})$ of 4 in $6 \mathrm{ml}$ of $\mathrm{CH}_{2} \mathrm{Cl}_{2}$ were added. The mixture was stirred overnight and then the yellow precipitate was filtered off under $\mathrm{N}_{2}$ and recrystallized from $\mathrm{CH}_{2} \mathrm{Cl}_{2}$. Orange needles. For $\mathrm{C}_{21} \mathrm{H}_{26} \mathrm{BF}_{4} \mathrm{NO}_{5} \times \mathrm{I} / 3$ $\mathrm{CH}_{2} \mathrm{Cl}_{2}$ (probably due to previous drying the amount of $\mathrm{CH}_{2} \mathrm{Cl}_{2}$ found by combustion analysis was smaller than that found by $\mathrm{X}$-ray analysis) Calc. $\mathrm{C}$ 52.5 H $5.51 \mathrm{~N} 2.9$ Found C 52.7 H 5.71 N 3.1. - $400 \mathrm{MHz}$ - ${ }^{1} \mathrm{H}-\mathrm{NMR}$ ( $\mathrm{CDCl}_{3}$; numbering according to Figure 3): $0.96\left(\mathrm{~s}, 3 \mathrm{H}, \mathrm{CH}_{3}\right), 1.09$ (s, 3H, $\left.\mathrm{CH}_{3}\right), 1.18\left(\mathrm{~s}, 3 \mathrm{H}, \mathrm{CH}_{3}\right), 1.85$ (ddd, J $=4.6 / 9 / 13.5 \mathrm{~Hz}, 1 \mathrm{H}, \mathrm{H}-5{ }^{\prime} \mathrm{ax}$ ), 1.98 (ddd, $\mathrm{J}=4.7 / 10.5 / 13.5 \mathrm{~Hz}, 1 \mathrm{H}, \mathrm{H}-5^{\prime} \mathrm{eq}$ ), 2.55 (ddd, $\mathrm{J}=4.6 / 10.5 / 14.3 \mathrm{~Hz}$, 1H, H-6'eq), 2.65 (ddd, J = 4.7/9/14.3 Hz, $1 \mathrm{H}, \mathrm{H}-6^{\prime} \mathrm{ax}$ ), 3.18-3.35 (m, $2 \mathrm{H}$, $\mathrm{H}-4), 3.91\left(\mathrm{~s}, 3 \mathrm{H}, \mathrm{OCH}_{3}\right), 4.08\left(\mathrm{~s}, 3 \mathrm{H}, \mathrm{OCH}_{3}\right), 4.12$ (dt, partly obscured, J $6.5 / 14 \mathrm{~Hz}, 1 \mathrm{H}, \mathrm{H}-3), 4.31$ (ddd, J $=5.5 / 6.5 / 14 \mathrm{~Hz}, 1 \mathrm{H}, \mathrm{H}-3), 6.95(\mathrm{~s}, 1 \mathrm{H}$, $\mathrm{H}-5), 7.51$ (s, $1 \mathrm{H}, \mathrm{H}-8), 9.41$ (s, $1 \mathrm{H}, \mathrm{H}-1)$.

(IS, 4R)-N-[2-(2-Formyl-4,5-dimethoxyphenyl)ethyll-1-carbamoyl-4,7,7trimethyl-2-oxa-bicyclo[2.2.1]heptan-3-one (2)

A $\mathrm{CH}_{2} \mathrm{Cl}_{2}$ suspension of 1 , obtained from $91 \mathrm{mg}(0.244 \mathrm{mmol})$ of 4 as described for 1 , was treated with $2 \mathrm{ml}$ of $\mathrm{H}_{2} \mathrm{O}$. After a few minutes the org. layer was washed with saturated $\mathrm{NaCl}$-solution (3x), dried over $\mathrm{MgSO}_{4}$ and evaporated to dryness under reduced pressure. The residue was purified by $\mathrm{CC}$ (n-hexane/ether $=1 / 9$ ). Colorless crystals, m.p. $129-132^{\circ} \mathrm{C}$, yield $24.8 \mathrm{mg}(26.1 \%)$. - $\mathrm{C}_{21} \mathrm{H}_{27} \mathrm{NO}_{6}$ (389.4) Calc. C $64.8 \mathrm{H} 6.99 \mathrm{~N} 3.6$ Found C 64.8 H 7.02 N 3.5. Mol.mass 389 (MS). - IR: 3400; 1785; 1670; $1600 ; 1510 \mathrm{~cm}^{-1}$. - $400 \mathrm{MHz}$ - ${ }^{1} \mathrm{H}-\mathrm{NMR}\left(\mathrm{CDCl}_{3}\right): 0.83\left(\mathrm{~s}, 3 \mathrm{H}, \mathrm{CH}_{3}\right), 1.08$ (s, $6 \mathrm{H}, 2 \mathrm{xCH}_{3}$ ), 1.66 (ddd, J $\sim 4 / 9 / 13 \mathrm{~Hz}, 1 \mathrm{H}$ ), 1.80-1.95 (m, 2H), 2.49 (ddd, 4/1 1/13 Hz, 1H), 3.17 (ddd, J 6//14 Hz, 1H), 3.26 (d, J 13.5/ $\mathrm{Hz}, 1 \mathrm{H}), 3.5-3.63(\mathrm{~m}, 2 \mathrm{H}), 3.92\left(\mathrm{~s}, 3 \mathrm{H}, \mathrm{OCH}_{3}\right), 3.94\left(\mathrm{~s}, 3 \mathrm{H}, \mathrm{OCH}_{3}\right), 6.67$ (h, unresolved, 1H, NH), 6.73 (s, 1H, Ar-H), 7.32 (s, 1H, Ar-H), 10.10 (s, $1 \mathrm{H}, \mathrm{CHO}$ ).

(IS, 4R)-1-(6,7-Dimethoxy-1,2,3,4-tetrahydro-2-isoquinolylcarbonyl)4,7,7-trimethyl-2-oxa-bicyclo[2.2.1]heptan-3-one (4)

To a stirred suspension of $3.99 \mathrm{~g}$ (17.37 mmol) of 5 in $30 \mathrm{ml}$ of $\mathrm{CH}_{2} \mathrm{Cl}_{2}$ at $0^{\circ} \mathrm{C} 5.76 \mathrm{ml}(41.65 \mathrm{mmol})$ of $\mathrm{NEt}_{3}$ were added, followed by $3.0 \mathrm{~g}(13.88$ mmol) of 6. After $15 \mathrm{~min}$ the mixture was allowed to warm to room temp. and stirred for $4 \mathrm{~h}$. The mixture was consecutively washed with $0.05 \mathrm{M}$ $\mathrm{HCl}(3 \mathrm{x})$ and saturated $\mathrm{NaCl}$-solution (3x) and dried over $\mathrm{MgSO}_{4}$ The solvent was evaporated in vacuo and the residue was purified by $\mathrm{CC}$ ( $\mathrm{n}$-hexane/ethyl acetate $=6 / 4)$. Colorless crystals, m.p. $140-142^{\circ} \mathrm{C},[\alpha]_{546}=-$ $21.0^{\circ},[\alpha]_{578}=-19.5^{\circ}\left(c=1.39, \mathrm{CH}_{3} \mathrm{OH}\right)$, yield $4.69 \mathrm{~g}(90.4 \%)$. $\mathrm{C}_{21} \mathrm{H}_{27} \mathrm{NO}_{5}$ (373.5) Calc. C 67.5 H 7.28 N 3.7 Found C 67.8 H 7.20 N 3.6. Mol. mass 373 (MS). - IR: 2960; $1780 ; 1630 ; 1510 \mathrm{~cm}^{-1}$. - $400 \mathrm{MHz}$ - ${ }^{1} \mathrm{H}-$ NMR $\left(\mathrm{CDCl}_{3}\right): 0.99\left(\mathrm{~s}, 0.4 \times 3 \mathrm{H}, \mathrm{CH}_{3}\right), 1.01\left(\mathrm{~s}, 0.6 \times 3 \mathrm{H}, \mathrm{CH}_{3}\right), 1.11$ (s, $\left.3 \mathrm{H}, \mathrm{CH}_{3}\right), 1.17\left(\mathrm{~s}, 0.4 \times 3 \mathrm{H}, \mathrm{CH}_{3}\right), 1.19\left(\mathrm{~s}, 0.6 \times 3 \mathrm{H}, \mathrm{CH}_{3}\right.$ ), 1.73 (ddd, J $4 / 9 / 13 \mathrm{~Hz}, 1 \mathrm{H}$ ), $1.88-1.98(\mathrm{~m}, 1 \mathrm{H}$ ), 2.00 (ddd, $\mathrm{J} \sim 4 / 9 / 13 \mathrm{~Hz}, 0.4 \times 1 \mathrm{H}$ ), 2.09 (ddd, J 4/9/13 Hz, $0.6 \times 1 \mathrm{H}$ ), 2.38 (ddd, J 4/11/13 Hz, $0.4 \times 1 \mathrm{H}$ ), 2.44 (ddd, $\mathrm{J} \sim 4 / 1 \mathrm{l} / 13 \mathrm{~Hz}, 0.6 \times 1 \mathrm{H}$ ), 2.73-2.79, $2.80-2.97$ ( $2 \times \mathrm{m}$, combined $2 \mathrm{H}$ ), 3.54 (ddd, $\mathrm{J}=4.4 / 8.5 / 12.9 \mathrm{~Hz}, 0.4 \times 1 \mathrm{H}$ ), 3.86, $3.87(2 \times \mathrm{s}$, combined $\left.6 \mathrm{H}, 2 \times \mathrm{OCH}_{3}\right), 3.81-3.88(\mathrm{~m}, 0.6 \times 1 \mathrm{H}$, signal overlapped by two $s$ at 3.86 and 3.87), 4.07-4.14(m, lH), $4.58(\mathrm{~d}, \mathrm{~J} \sim 16.9 \mathrm{~Hz}, 0.6 \times 1 \mathrm{H}$, $\left.\mathrm{NCH}_{2} \mathrm{Ar}\right), 4.76\left(\mathrm{~d}, \mathrm{~J} \sim 16.9 \mathrm{~Hz}, 0.6 \times 1 \mathrm{H}, \mathrm{NCH}_{2} \mathrm{Ar}\right), 4.81(\mathrm{~d}, \mathrm{~J} \sim 16.9 \mathrm{~Hz}$, $\left.0.4 \times 1 \mathrm{H}, \mathrm{NCH}_{2} \mathrm{Ar}\right), 4.92\left(\mathrm{~d}, \mathrm{~J} \sim 16.9 \mathrm{~Hz}, 0.4 \times 1 \mathrm{H}, \mathrm{NCH}_{2} \mathrm{Ar}\right), 6.60,6.61$ (2xs, comb. $2 \mathrm{H}$, Ar-H). Ratio of atropisomers $\sim 2: 3$.

(IS, 4R)-1-[(IR)-1,2,3,4-Tetrahydro-6,7-dimethoxy-1-(2-0xo-2-phenyl-1ethyl)-2-isoquinolylcarbonyl]-4,7,7-trimethyl-2-oxa-bicyclo[2.2.1] heptan3-one $(R)-8 \mathrm{a}$ and $(1 S, 4 R)-1-1($ IS)-1,2,3,4-Tetrahydro-6,7-dimethoxy1-(2-oxo-2-phenyl-1-ethyl)-2-isoquinolylcarbonyl] -4,7,7-trimethyl-2oxa-bicyclo[2.2.1] heptan-3-one (S)-9a

a) To a stirred solution of $2.30 \mathrm{~g}$ (6.97 mmol) of triphenylcarbenium tetrafluoroborate (3) in $30 \mathrm{ml}$ of $\mathrm{CH}_{2} \mathrm{Cl}_{2} 2.17 \mathrm{~g}(5.81 \mathrm{mmol})$ of 4 in 30 $\mathrm{ml}$ of $\mathrm{CH}_{2} \mathrm{Cl}_{2}$ were added. The resulting solution was stirred for $16 \mathrm{~h}$ at room temp. The yellow precipitate formed was dissolved by addition of $85 \mathrm{ml}$ of $\mathrm{CH}_{2} \mathrm{Cl}_{2}$ and the solution was cooled to $-78^{\circ} \mathrm{C}$. A solution of $1.60 \mathrm{ml}(14.53 \mathrm{mmol})$ of $\mathrm{TiCl}_{4}$ in $0.85 \mathrm{ml}$ of $\mathrm{CH}_{2} \mathrm{Cl}_{2}$ was added dropwise, followed by $1.34 \mathrm{~g}(6.98 \mathrm{mmol})$ of $7 \mathrm{a}$ dissolved in $3.55 \mathrm{ml}$ of $\mathrm{CH}_{2} \mathrm{Cl}_{2}$. The mixture was stirred for $1 \mathrm{~h}$ and $45 \mathrm{~min}$ at $-78^{\circ} \mathrm{C}$ and then quenched by addition of $40 \mathrm{ml}$ of $\mathrm{H}_{2} \mathrm{O}$. The org. layer was washed with saturated $\mathrm{NaCl}$-solution (3x), dried over $\mathrm{MgSO}_{4}$ and evaporated under reduced pressure. The residue was purified by $\mathrm{CC}$ $\left(\mathrm{CH}_{2} \mathrm{Cl}_{2} / \mathrm{Et}_{2} \mathrm{O}=97 / 3\right)$. A colorless solid containing (R)-8a and (S)-9a was obtained. The ratio of $(\mathbf{R})-8 \mathrm{a} /(\mathbf{S})-(9 \mathrm{a})$ was determined by HPLC (from the crude product; chiral column, n-hexane/isopropanol $=8 / 2$ ): Table 1, entry 8. Yield $2.22 \mathrm{~g}(77.8 \%)$. $\mathrm{C}_{29} \mathrm{H}_{33} \mathrm{NO}_{6}$ (491.5) Calc. C 70.9 H 6.77 N 2.9 Found C 70.9 H 6.91 N 2.7. Mol. mass 491 (MS). IR: $1790 ; 1680 ; 1640 ; 1510 \mathrm{~cm}^{-1}$. - Separation of the diastereomers was effected by prep. HPLC (chiral column, $n$-hexane/isopropanol = 7:3). From a $86 \mathrm{mg}$ sample $((\mathrm{R})-8 \mathrm{a} /(\mathrm{S})-9 \mathrm{a}=91.2 / 8.8) 51 \mathrm{mg}$ of $(\mathrm{R})-8 \mathrm{a}$ ( $59.3 \%$; de $>99.5 \%$ ) was obtained.

(R)-8a: Colorless crystals, m.p. $90-95^{\circ} \mathrm{C},[\alpha]_{546}=-165.3^{\circ},[\alpha]_{578}=-$ $144.4^{\circ}\left(\mathrm{c}=0.72, \mathrm{CH}_{3} \mathrm{OH}\right) .-400 \mathrm{MHz}-\mathrm{H}^{\mathrm{H}}-\mathrm{NMR}\left(\mathrm{CDCl}_{3}\right) ; 0.92(\mathrm{~s}, 0.7$ $\left.\times 3 \mathrm{H}, \mathrm{CH}_{3}\right), 0.94\left(\mathrm{~s}, 0.3 \times 3 \mathrm{H}, \mathrm{CH}_{3}\right), 1.06\left(\mathrm{~s}, 0.3 \times 3 \mathrm{H}, \mathrm{CH}_{3}\right), 1.07(\mathrm{~s}$. $\left.0.7 \times 3 \mathrm{H}, \mathrm{CH}_{3}\right), 1.12\left(\mathrm{~s}, 0.7 \times 3 \mathrm{H}, \mathrm{CH}_{3}\right), 1.19\left(\mathrm{~s}, 0.3 \times 3 \mathrm{H}, \mathrm{CH}_{3}\right), 1.68$ 
(ddd, J 4/9/13 Hz, $0.7 \times 1 \mathrm{H}$ ), 1.75 (ddd, partly obscured, J 4/9/13 $\mathrm{Hz}, 0.3 \times 1 \mathrm{H}$ ), 1.87 (ddd, J 4/11/13 Hz, 1H), 1.97 (ddd, J 4/9/13 $\mathrm{Hz}, 0.7 \times 1 \mathrm{H}$ ), 2.05 (ddd, partly obscured, J $\sim 4 / 9 / 13 \mathrm{~Hz}, 0.3 \times 1 \mathrm{H}$ ), 2.13 (ddd, J 4/11/13 Hz, $0.7 \times 1 \mathrm{H}$ ), 2.24 (ddd, J 4/11/13 Hz, $0.3 \times$ 1H), $2.74(\mathrm{dt}, J \sim 16 / 3 \mathrm{~Hz}, 1 \mathrm{H}), 2.97-3.05(\mathrm{~m}$, partly obscured, $0.3 \times$ 1H), 3.08 (ddd, J 5/11/16 Hz, $0.7 \times 1 \mathrm{H}$ ), 3.28 (ddd. J 4/11/12 Hz, $0.3 \times 1 \mathrm{H}), 3.38-3.49(\mathrm{~m}, 2 \mathrm{H}), 3.57$ (ddd, $\mathrm{J} \sim 4 / 11 / 13 \mathrm{~Hz}, 0.7 \times 1 \mathrm{H}$ ), $3.74\left(\mathrm{~s}, 0.3 \times 3 \mathrm{H}, \mathrm{OCH}_{3}\right), 3.78\left(\mathrm{~s}, 0.7 \times 3 \mathrm{H}, \mathrm{OCH}_{3}\right), 3.84(\mathrm{~s}, 0.3 \times 3 \mathrm{H}$, $\mathrm{OCH}_{3}$ ), 3.85 (s. $\left.0.7 \times 3 \mathrm{H}, \mathrm{OCH}_{3}\right), 4.46$ (ddd, J 3/5/13 Hz, $0.7 \times 1 \mathrm{H}$ ), 4.57 (ddd, unresolved, $0.3 \times 1 \mathrm{H}), 6.03(\mathrm{l}, \mathrm{J}=6.6 \mathrm{~Hz}, 1 \mathrm{H}, \mathrm{NCHAr}$ ), 6.60 (s, 1H, Ar-H), 6.69 (s, $0.7 \times 1 \mathrm{H}, \mathrm{Ar}-\mathrm{H}), 6.81$ (s, $0.3 \times 1 \mathrm{H}, \mathrm{Ar}-\mathrm{H})$, 7.44-7.59 (m, 3H, Ar-H), 7.97-8.00 (m, 2H, Ar-H). Ratio of atropisomers -37 .

(S)-9a: $400 \mathrm{MHz}-{ }^{1} \mathrm{H}-\mathrm{NMR}\left(\mathrm{CDCl}_{3}\right): 0.90$ (s, 3H, $\left.\mathrm{CH}_{3}\right), 1.07$ (s, 3H, $\mathrm{CH}_{3}$ ), $1.08\left(\mathrm{~s}, 3 \mathrm{H}, \mathrm{CH}_{3}\right.$ ), 1.65 (ddd, J 4/9/13 Hz, IH), I.88 (ddd, J $4 / 11 / 13 \mathrm{~Hz}, 1 \mathrm{H}$ ), 1.97 (ddd, J $\sim 4 / 9 / 13 \mathrm{~Hz}, 1 \mathrm{H}$ ), 2.43 (ddd, J 4/1 1/13 $\mathrm{Hz}, 1 \mathrm{H}$ ), 2.78 (dt, J 16/4 Hz, 1H), 2.92 (ddd, J 5/11/16 Hz, 1H), 3.37 (dd, $J=5.6 / 14.9 \mathrm{~Hz}, 1 \mathrm{H}$ ), 3.46 (dd, $J=7.2 / 14.9 \mathrm{~Hz}, 1 \mathrm{H}$ ), 3.70 (ddd, J 4/11/14 Hz, IH), $3.80\left(\mathrm{~s}, 3 \mathrm{H}, \mathrm{OCH}_{3}\right), 3.85\left(\mathrm{~s}, 3 \mathrm{H}, \mathrm{OCH}_{3}\right)$, 4.56 (ddd, $\mathrm{J} \sim 4 / 5 / 14 \mathrm{~Hz}, 0.8 \times 1 \mathrm{H}, \mathrm{NCH}_{2} \mathrm{CH}_{2} \mathrm{Ar}$ ), 4.66 (ddd, J $3 / 5 / 13 \mathrm{~Hz}, 0.2 \times 1 \mathrm{H}, \mathrm{NCH}_{2} \mathrm{CH}_{2} \mathrm{Ar}$ ), 6.18 (pseudo-t, J $6.5 \mathrm{~Hz}, 0.8 \times$ 1H, NCHAr), 6.30 (dd, J $\sim 57.7 \mathrm{~Hz}, 0.2 \times 1 \mathrm{H}, \mathrm{NCHAr}$ ), 6.59 (s, $1 \mathrm{H}$, Ar-H), $6.70(\mathrm{~s}, 1 \mathrm{H}, \mathrm{Ar}-\mathrm{H}), 7.447 .49(\mathrm{~m}, 2 \mathrm{H}, \mathrm{Ar}-\mathrm{H}), 7.55-7.59(\mathrm{~m}, 1 \mathrm{H}$, Ar-H), 7.96-7.99 (m, 2H, Ar-H). Ratio of atropisomers 2/8.

The following experiments were preformed as described under a).

b) From $1.755 \mathrm{~g}(5.32 \mathrm{mmol})$ of $3,1.805 \mathrm{~g}(4.83 \mathrm{mmol})$ of 4 and $1.116 \mathrm{~g}$ $\left(5.80 \mathrm{mmol}\right.$ ) of $7 \mathrm{a}$. $\mathrm{No} \mathrm{TiCl}_{4}$, addition of $7 \mathrm{a}$ at $-90^{\circ} \mathrm{C}$. Yield $2.309 \mathrm{~g}$ (97.2\%). Ratio (R)-8a/(S)-9a: Table 1 entry 2.

c) From $60 \mathrm{mg}(0.181 \mathrm{mmol})$ of $3,61 \mathrm{mg}(0.164 \mathrm{mmol})$ of 4 and $38 \mathrm{mg}$ $(0.197 \mathrm{mmol})$ of $7 \mathrm{a}$. No $\mathrm{TiCl}_{4}$, addition of $7 \mathrm{a}$ at $-78^{\circ} \mathrm{C}$. Ratio (R)8a/(S)-9a: Table 1, entry 1.

d) From $87 \mathrm{mg}(0.263 \mathrm{mmol})$ of $3,82 \mathrm{mg}(0.219 \mathrm{mmol})$ of $4,21 \mathrm{mg}$ $(0.110 \mathrm{mmol})$ of $\mathrm{TiCl}_{4}$ and $51 \mathrm{mg}(0.263 \mathrm{mmol})$ of $7 \mathrm{a}$. Ratio (R)8a/(S)-9a: Table 1, entry 3.

e) From $90 \mathrm{mg}(0.271 \mathrm{mmol})$ of $3,92 \mathrm{mg}(0.247 \mathrm{mmol})$ of $4,47 \mathrm{mg}$ $(0.247 \mathrm{mmol})$ of $\mathrm{TiCl}_{4}, 57 \mathrm{mg}(0.296 \mathrm{mmol})$ of 72 . Ratio (R)-8a/(S)9a: Table 1, entry 4.

f) From $85 \mathrm{mg}(0.256 \mathrm{mmol})$ of $3,80 \mathrm{mg}(0.214 \mathrm{mmol})$ of $4,41 \mathrm{mg}$ $(0.214 \mathrm{mmol})$ of $\mathrm{TiCl}_{4}, 49.3 \mathrm{mg}(0.256 \mathrm{mmol})$ of $7 \mathrm{a}$. Ratio (R)-8a/(S)9a: Table 1, entry 5.

g) From $85 \mathrm{mg}(0.257 \mathrm{mmol})$ of $3,80 \mathrm{mg}(0.214 \mathrm{mmol})$ of $4,61 \mathrm{mg}$ $(0.322 \mathrm{mmol})$ of $\mathrm{TiCl}_{4}, 50 \mathrm{mg}(0.257 \mathrm{mmol})$ of $7 \mathrm{a}$. Ratio (R)-8a/(S)9a: Table 1, entry 6.

h) From $107 \mathrm{mg}(0.325 \mathrm{mmol})$ of $3,101 \mathrm{mg}(0.271 \mathrm{mmol})$ of $4,103 \mathrm{mg}$ $(0.543 \mathrm{mmol})$ of $\mathrm{TiCl}_{4}, 63 \mathrm{mg}(0.325 \mathrm{mmol})$ of $7 \mathrm{a}$. Ratio (R)-8a/(S)9a: Table 1, entry 7.

i) From $87 \mathrm{mg}(0.265 \mathrm{mmol})$ of $3.82 \mathrm{mg}(0.221 \mathrm{mmol})$ of $4,126 \mathrm{mg}$ $(0.662 \mathrm{mmol})$ of $\mathrm{TiCl}_{4}, 51 \mathrm{mg}(0.265 \mathrm{mmol})$ of $7 \mathrm{a}$. Ratio (R)-8a/(S)9a: Table 1, entry 9.

j) From $97 \mathrm{mg}(0.295 \mathrm{mmol})$ of $3.92 \mathrm{mg}(0.246 \mathrm{mmol})$ of $4,163 \mathrm{mg}$ $(0.860 \mathrm{mmol})$ of $\mathrm{TiCl}_{4}, 57 \mathrm{mg}(0.295 \mathrm{mmol})$ of $7 \mathrm{a}$. Ratio (R)-8a/(S)9a: Table 1, entry 10 .

(IS,4R)-I-((IR)-1,2,3,4-Tetrahydro-6,7-dimethoxy-1-(2-(4-chlorophenyl)-2 -oxo-1-ethyl]-2-isoquinolylcarbonyl]-4,7,7-trimethyl-2-oxa-bicyclo[2.2.1]heptan-3-one (R)-8b and (IS, 4R)-1-\{(IS)-1,2,3,4-Tetrahydro-6,7dimethoxy-1-(2-(4-chlorophenyl-2-oxo-1-ethyl)-2-isoquinolylcarbonyl)4,7,7-trimethyl-2-oxa-bicyclo[2.2.1]heptan-3-one (S)-9b.

From $1.46 \mathrm{~g}(4.42 \mathrm{mmol})$ of $3,1.50 \mathrm{~g}(4.02 \mathrm{mmol})$ of 4 and $1.0 \mathrm{~g}(4.42$ mmol) of $7 \mathrm{~b}$ as described for (R)-8a/(S)-9a a). Without $\mathrm{TiCl}_{4}$; addition of Tb at $-78^{\circ} \mathrm{C}$. Solvent for $\mathrm{CC}$ : $\mathrm{n}$-hexane/ethyl acetate $=65 / 35$. A colorless solid containing (R)-8b and (S)-9b was obtained. Yield $2.09 \mathrm{~g}(98.9 \%)$. Ratio of (R)-8b/(S)-9b determined by HPLC (chiral column, n-hexane/isopropanol = 85/15): Table 1, entry 11. $-\mathrm{C}_{29} \mathrm{H}_{32} \mathrm{ClNO}_{6}(526.0)$ Calc. C 66.2
H 6.13 N 2.7 Found C 66.1 H 6.34 N 2.5. Mol. mass 526 (MS). - IR: 1785; 1675; $1640 ; 1510 \mathrm{~cm}^{-1}$. - Separation of the diastereomers was effected by prep. HPLC (chiral column, n-hexane/ethyl acetate $=7 / 3$ ). From a $87 \mathrm{mg}$ sample $((R)-8 b /(S)-9 b=93.9 / 6.1) 60 \mathrm{mg}$ of $(R)-8 b \quad(70.0 \%$; de>99.5\%) and small amounts of (S)-9b were obtained.

(R)-8b: $400 \mathrm{MHz}-{ }^{1} \mathrm{H}-\mathrm{NMR}\left(\mathrm{CDCl}_{3}\right): 0.92$ (s, $\left.0.75 \times 3 \mathrm{H}, \mathrm{CH}_{3}\right), 0.94$ (s, $\left.0.25 \times 3 \mathrm{H}, \mathrm{CH}_{3}\right), 1.06\left(\mathrm{~s}, 0.25 \times 3 \mathrm{H}, \mathrm{CH}_{3}\right), 1.08\left(\mathrm{~s}, 0.75 \times 3 \mathrm{H}, \mathrm{CH}_{3}\right), 1.12$ (s, $0.75 \times 3 \mathrm{H}, \mathrm{CH}_{3}$ ), 1.20 (s, $0.25 \times 3 \mathrm{H}, \mathrm{CH}_{3}$ ), 1.71 (ddd, J $\sim 4 / 9 / 13 \mathrm{~Hz}$, 1H), 1.91 (ddd, J 4/11/13 Hz, 1H), 2.02 (ddd, J 4/9/13 Hz, 1H), 2.19 (ddd, J 4/11/13 Hz, 1H), 2.74 (dt, J 16/3.6 Hz, 1H), 2.95-3.05 (m, partly obscured, $0.25 \times 1 \mathrm{H}$ ), 3.08 (ddd, J $\sim 5 / 11 / 16 \mathrm{~Hz}, 0.75 \times 1 \mathrm{H}$ ), 3.34 (dd, J $-6.8 / 14 \mathrm{~Hz}, 1 \mathrm{H}$ ), 3.43 (dd, J 6.8/14 Hz, 1H), 3.55 (ddd, J $~ 3.6 / 11 / 13 \mathrm{~Hz}$, 1H), $3.74\left(\mathrm{~s}, 0.25 \times 3 \mathrm{H}, \mathrm{OCH}_{3}\right), 3.79\left(\mathrm{~s}, 0.75 \times 3 \mathrm{H}, \mathrm{OCH}_{3}\right), 3.84(\mathrm{~s}, 0.25 \times$ $3 \mathrm{H}, \mathrm{OCH}_{3}$ ), $3.85\left(\mathrm{~s}, 0.75 \times 3 \mathrm{H}, \mathrm{OCH}_{3}\right), 4.46$ (ddd, J 3/5/13 Hz, $0.75 \times$ $1 \mathrm{H}, \mathrm{NCH}_{2} \mathrm{CH}_{2} \mathrm{Ar}$ ), 4.56 (ddd, $\mathrm{J} \sim 3 / 5 / 13 \mathrm{~Hz}, 0.25 \times 1 \mathrm{H}, \mathrm{NCH}_{2} \mathrm{CH}_{2} \mathrm{Ar}$ ), $5.98(\mathrm{t}, \mathrm{J} \sim 6.8 \mathrm{~Hz}, 1 \mathrm{H}, \mathrm{NCHAr}), 6.60(\mathrm{~s}, 1 \mathrm{H}, \mathrm{Ar}-\mathrm{H}), 6.65(\mathrm{~s}, 0.75 \times 1 \mathrm{H}$ Ar-H), 6.76 (s, 0.25 x 1H, Ar-H), 7.43-7.47 (m, 2H, Ar-H), 7.90-7.96 (m, $2 \mathrm{H}, \mathrm{Ar}-\mathrm{H})$. Ratio of atropisomers $\sim 75 / 25$.

(S)-9b: $400 \mathrm{MHz}-{ }^{1} \mathrm{H}-\mathrm{NMR}\left(\mathrm{CDCl}_{3}\right): 0.94\left(\mathrm{~s}, 3 \mathrm{H}, \mathrm{CH}_{3}\right), 1.07$ (s, 3H, $\mathrm{CH}_{3}$ ), $1.10\left(\mathrm{~s}, 3 \mathrm{H}, \mathrm{CH}_{3}\right.$ ), 1.66 (ddd, J $\sim 4 / 9 / 13 \mathrm{~Hz}, 1 \mathrm{H}$ ), 1.87 (ddd, J $4 / 11 / 13 \mathrm{~Hz}, 1 \mathrm{H}$ ), 1.97 (ddd, J 4/9/13 Hz, 1H); 2.42 (ddd, J 4/1 1/13 Hz, 1H), 2.77 (dt, J 16/3 Hz, 1H), 2.92 (ddd, J 5/11/16 Hz, 1H), 3.37 (m, 2H), 3.68 (ddd, J 3/11/14 Hz, 1H), 3.81 (s, 3H, OCH $), 3.85(\mathrm{~s}, 3 \mathrm{H}$, $\mathrm{OCH}_{3}$ ), 4.54 (ddd, J $~ 3 / 5 / 14 \mathrm{~Hz}, 1 \mathrm{H}, \mathrm{NCH}_{2} \mathrm{CH}_{2} \mathrm{Ar}$ ), $6.12(\mathrm{t}, \mathrm{J} \sim 6.5 \mathrm{~Hz}$, $0.85 \times 1 \mathrm{H}, \mathrm{NCHAr}), 6.23-6.28(\mathrm{~m}, 0.15 \times 1 \mathrm{H}, \mathrm{NCHAr}), 6.60(\mathrm{~s}, 1 \mathrm{H}, \mathrm{Ar}-\mathrm{H})$, 6.67 (s, $1 \mathrm{H}, \mathrm{Ar}-\mathrm{H}), 7.42-7.46(\mathrm{~m}, 2 \mathrm{H}, \mathrm{Ar}-\mathrm{H}), 7.88-7.94$ (m, 2H, Ar-H). Ratio of atropisomers $-85 / 15$.

(IS, 4R)-1-\{(IR)-1,23,4-Tetrahydro-6,7-dimethoxy-1-12-(3,4-dimethoxyphenyl)-2-oxo-1-ethyl]-2-isoquinolylcarbonyl]-4,7,7-trimethyl-2-oxabicyclo(2.2.1 Jheptan-3-one (R)-8c and (IS, 4R)-I-\{(IS)-1,2,3,4-

Tetrahydro-6,7-dimethoxy-1-[2-(3,4-dimethoxyphenyl)-2-oxo-1-ethyl] 2-isoquinolylcarbonyl]-4,7,7-trimethyl-2-oxa-bicyclo[2.2.1] heptan-3-one (S)-9c

From $1.79 \mathrm{~g}(5.42 \mathrm{mmol})$ of $3,1.83 \mathrm{~g}(4.90 \mathrm{mmol})$ of 4 and $1.54 \mathrm{~g}(6.08$ mmol) of $7 \mathrm{c}$ as described for (R)-82/(S)-9a a). Without $\mathrm{TiCl}_{4}$; addition of $7 \mathrm{c}$ at $-78^{\circ} \mathrm{C}, 20 \mathrm{~h}$ reaction time. A mixture of $(\mathrm{R})-8 \mathrm{c} /(\mathrm{S})-9 \mathrm{c}$ was obtained as a colorless solid after $C C$ (n-hexane/ethyl acetate $=1 / 1$ ). Yield $2.61 \mathrm{~g}$ (96.8\%). Ratio of (R)-8d/(S)-9c determined by HPLC (chiral column, $n$ hexane/isopropanol $=60 / 40$ ): Table 1 , entry $12 .-\mathrm{C}_{31} \mathrm{H}_{37} \mathrm{NO}_{8}(551.6) \mathrm{Calc}$. C 67.5 H 6.76 N 2.5 Found C 67.5 H 6.80 N 2.5. Mol. mass 551 (MS). IR: $1790 ; 1670 ; 1640 ; 1520 \mathrm{~cm}^{-1}$. The diastereomers were separable by prep. HPLC (chiral column, $\mathrm{n}$-hexane/ethyl acetate $=1 / 1$ ). From a $87 \mathrm{mg}$ sample $((R)-8 c /(S)-9 c=82.4 / 17.6) 50 \mathrm{mg}(R)-8 \mathrm{c}(57.1 \%$; de>99.5\%) and minute amounts of $(S)-9 \mathrm{c}$ were obtained.

(R)-8c: $400 \mathrm{MHz}-{ }^{1} \mathrm{H}-\mathrm{NMR}\left(\mathrm{CDCl}_{3}\right): 0.94\left(\mathrm{~s}, 0.75 \times 3 \mathrm{H}, \mathrm{CH}_{3}\right), 0.95$ (s, $\left.0.25 \times 3 \mathrm{H}, \mathrm{CH}_{3}\right), 1.07\left(\mathrm{~s}, 0.25 \times 3 \mathrm{H}, \mathrm{CH}_{3}\right), 1.08\left(\mathrm{~s}, 0.75 \times 3 \mathrm{H}, \mathrm{CH}_{3}\right), 1.14$ (s. $0.75 \times 3 \mathrm{H}, \mathrm{CH}_{3}$ ), 1.20 (s, $0.25 \times 3 \mathrm{H}, \mathrm{CH}_{3}$ ), 1.70 (ddd, J $\sim 4 / 9 / 13 \mathrm{~Hz}$, 1H), 1.90 (ddd, J 4/1 1/13 Hz, 1H), 2.00 (ddd, J 4/9/13 Hz, 1H), 2.20 (ddd, J 4/11/13 Hz, 1H), 2.75 (dt, J $\sim 16 / 3 \mathrm{~Hz}, 1 \mathrm{H}$ ), 3.07 (ddd, J $5 / 11 / 16 \mathrm{~Hz}, 1 \mathrm{H}$ ), 3.33 (dd, $\mathrm{J}=6.5 / 14 \mathrm{~Hz}, 1 \mathrm{H}$ ), 3.44 (dd, $\mathrm{J}=6.5 / 14 \mathrm{~Hz}$, 1H), 3.56 (ddd, J 3/1 1/13 Hz, 1H), 3.72 (s, $0.25 \times 3 \mathrm{H}, \mathrm{OCH}_{3}$ ), 3.76 (s, $\left.0.75 \times 3 \mathrm{H}, \mathrm{OCH}_{3}\right), 3.83\left(\mathrm{~s}, 0.25 \times 3 \mathrm{H}, \mathrm{OCH}_{3}\right), 3.85\left(\mathrm{~s}, 0.75 \times 3 \mathrm{H}, \mathrm{OCH}_{3}\right)$, $3.92\left(\mathrm{~s}, 0.25 \times 6 \mathrm{H}, \mathrm{OCH}_{3}\right), 3.94\left(\mathrm{~s}, 0.25 \times 6 \mathrm{H}, \mathrm{OCH}_{3}\right), 3.96(\mathrm{~s}, 1.5 \times 6 \mathrm{H}$, $\mathrm{OCH}_{3}$ ), 4.46 (ddd, J 3/5/13 Hz, $0.75 \times 1 \mathrm{H}, \mathrm{NCH}_{2} \mathrm{CH}_{2} \mathrm{Ar}$ ), 4.59 (ddd, $\left.\mathrm{J}=3 / 5 / 13 \mathrm{~Hz}, 0.25 \times 1 \mathrm{H}, \mathrm{NCH}_{2} \mathrm{CH}_{2} \mathrm{Ar}\right), 6.00(\mathrm{t}, \mathrm{J}=6.5 \mathrm{~Hz}, 1 \mathrm{H}, \mathrm{NCHAr})$, 6.59, 6.60, 6.73 (3xs, combined 2H, Ar-H), 6.88-6.93 (m, 1H, Ar-H), 7.557.68 (m, 2H, Ar-H). Ratio of atropisomers $-25 / 75$.

(S)-9c: $400 \mathrm{MHz}-{ }^{1} \mathrm{H}-\mathrm{NMR}\left(\mathrm{CDCl}_{3}\right): 0.86\left(\mathrm{~s}, 3 \mathrm{H}, \mathrm{CH}_{3}\right), 1.07$ (s, 3H, $\mathrm{CH}_{3}$ ), 1.08 (s, 3H, $\mathrm{CH}_{3}$ ), 1.66 (ddd, J 4/9/13 Hz, 1H), 1.87 (ddd, J $4 / 1 \mathrm{l} / 13 \mathrm{~Hz}, 1 \mathrm{H}$ ), 1.98 (ddd, J $\sim 4 / 9 / 13 \mathrm{~Hz}, 1 \mathrm{H}$ ), 2.40 (ddd, J 4/11/13 Hz, IH), 2.78 (dt, J 16/4 Hz, IH), 2.91 (ddd, J 5/11/16 Hz, IH), 3.23 (dd, J - 7/14.3 Hz, IH), 3.48 (dd, J 7/14.3 Hz, 1H), 3.66-3.73 (m, 1H), 3.80, 
3.85, 3.94, 3.95 (4xs, combined $12 \mathrm{H}, 4 \times \mathrm{OCH}_{3}$ ), 4.57 (ddd, J 4/5/13 Hz, 1H, $\mathrm{NCH}_{2} \mathrm{CH}_{2} \mathrm{Ar}$ ), 6.14 (h, J $\left.7 \mathrm{~Hz}, 1 \mathrm{H}, \mathrm{NCHAr}\right), 6.59$ (s, $\left.\mathrm{lH}, \mathrm{Ar}-\mathrm{H}\right), 6.66$ (s, IH, Ar-H), 6.91-6.93 (m, 1H, Ar-H), 7.52-7.67 (m, 2H, Ar-H). Signals of minor atropisomer of very low intensity.

(IS, 4R)-1-\{(IR)-1,2,3,4-Tetrahydro-6,7-dimethoxy-1-[2-(2,4,6-trimethylphenyl)-2-oxo-1-ethylj-2-isoquinolylcarbonyl\}-4,7,7-trimethyl-2-oxabicyclo/2.2.1]heptan-3-one $(R)-11 \mathrm{a}$ and $(I S, 4 R)-I-\{(I S)-1,2,3,4-$ Tetrahydro-6,7-dimethoxy-1-[2-(2,4,6-trimethylphenyl)-2-oxo-1-ethyl]2-isoquinolylcarbonyl]-4,7,7-trimethyl-2-oxa-bicyclo[2.2.1]heptan-3-one (S)-12a

From $567 \mathrm{mg}\left(1.72 \mathrm{mmol}\right.$ ) of $3 \mathrm{in} 10 \mathrm{ml}$ of $\mathrm{CH}_{2} \mathrm{Cl}_{2}, 535 \mathrm{mg}$ (1.43 mmol) of 4 in $10 \mathrm{ml}$ of $\mathrm{CH}_{2} \mathrm{Cl}_{2}$ (dilution with $15 \mathrm{ml}$ of $\mathrm{CH}_{2} \mathrm{Cl}_{2}$ prior to addition of 10a) and $672 \mathrm{mg}$ ( $2.86 \mathrm{mmol}$ ) of $10 \mathrm{a}$ (in $0.4 \mathrm{ml}$ of $\mathrm{CH}_{2} \mathrm{Cl}_{2}$ ) as described for (R)-8a/(S)-9a, but without $\mathrm{TiCl}_{4}$. Addition of $10 \mathrm{a}$ at $-78^{\circ} \mathrm{C}, 2 \mathrm{~h}$ reaction time. After aqueous work-up a crude product containing (R)-11a/(S)-12a was obtained. Ratio of $(\mathrm{R})-11 \mathrm{a} /(\mathrm{S})$-12a determined by HPLC $\left(\mathrm{SiO}_{2}, \mathrm{n}\right.$-hexane $/ \mathrm{Et}_{2} \mathrm{O}=6 / 4,2.0 \mathrm{mV} / \mathrm{min}$, major isomer $15.3 \mathrm{~min}$, minor isomer 18.3 min; ratio: Table 2, entry 1). Pure diastereomers were obtained after $\mathbf{C C}$ (nhexane/ $\mathrm{Et}_{2} \mathrm{O}=6 / 4$ ).

Major isomer: Colorless crystals, m.p. $155-157^{\circ} \mathrm{C},[\alpha]_{546}=-94.0^{\circ},[\alpha]_{578}$ $=-82.1^{\circ}\left(\mathrm{c}=0.67, \mathrm{CH}_{3} \mathrm{OH}\right)$, yield $83 \mathrm{mg}(10.8 \%$, de $299.3 \%) .-\mathrm{C}_{32} \mathrm{H}_{39} \mathrm{NO}_{6}$ (533.7). Calc. C 72.0 H 7.37 N 2.6 Found C. 72.1 H 7.39 N 2.5 Mol. mass 533 (MS). - IR: 1785; 1700; 1635; $1510 \mathrm{~cm}^{-1}$. $400 \mathrm{MHz}$ - ' ${ }^{1} \mathrm{H}-\mathrm{NMR}$ $\left(\mathrm{CDCl}_{3}\right): 0.98\left(\mathrm{~s}, 0.65 \times 3 \mathrm{H}, \mathrm{CH}_{3}\right), 1.01\left(\mathrm{~s}, 0.35 \times 3 \mathrm{H}, \mathrm{CH}_{3}\right), 1.10(\mathrm{~s}, 3 \mathrm{H}$, $\left.\mathrm{CH}_{3}\right), 1.21\left(\mathrm{~s}, 0.65 \times 3 \mathrm{H}, \mathrm{CH}_{3}\right), 1.22\left(\mathrm{~s}, 0.35 \times 3 \mathrm{H}, \mathrm{CH}_{3}\right), 1.72$ (ddd, J $4 / 9 / 13 \mathrm{~Hz}, 1 \mathrm{H}$ ), 1.80-1.97 (m, 2H), 2.08 (s, 3H, Ar- $\mathrm{CH}_{3}$ ), 2.11 (s, 3H, Ar$\left.\mathrm{CH}_{3}\right), 2.24$ (s, $\left.0.35 \times 3 \mathrm{H}, \mathrm{Ar}-\mathrm{CH}_{3}\right), 2.25\left(\mathrm{~s}, 0.65 \times 3 \mathrm{H}, \mathrm{Ar}-\mathrm{CH}_{3}\right), 2.36$ (ddd, $\mathrm{J} \sim 4 / 11 / 13 \mathrm{~Hz}, \mathrm{lH}$ ), 2.67-2.75 (m, 1H), 2.93-3.15 (m), 3.12 (dd, J 4/18 $\mathrm{Hz}, 2.93-3.12$ combined $2 \mathrm{H}$ ), 3.26 (dd, $\mathrm{J} \sim 7.5 / 18 \mathrm{~Hz}, 1 \mathrm{H}$ combined with a signal obscured), 3.39-3.50 (m, $1 \mathrm{H}), 3.83\left(\mathrm{~s}, 0.65 \times 3 \mathrm{H}, \mathrm{OCH}_{3}\right), 3.85(\mathrm{~s}$, $\left.0.35 \times 3 \mathrm{H}, \mathrm{OCH}_{3}\right), 3.86\left(\mathrm{~s}, 0.65 \times 3 \mathrm{H}, \mathrm{OCH}_{3}\right), 3.87\left(\mathrm{~s}, 0.35 \times 3 \mathrm{H}, \mathrm{OCH}_{3}\right)$, 4.39-4.44 (m, $1 \mathrm{H}, \mathrm{NCH}_{2} \mathrm{CH}_{2} \mathrm{Ar}$ ), 6.13 (dd, $\mathrm{J} \sim 4 / 7.5 \mathrm{~Hz}$, signal of minor atropisomer obscured, 1H, NCHAr), 6.60 (s, $0.65 \times 1 \mathrm{H}, \mathrm{Ar}-\mathrm{H}), 6.61$ (s, $0.35 \times 1 \mathrm{H}, \mathrm{Ar}-\mathrm{H}), 6.78,6.79(2 \times \mathrm{s}$, combined $2 \mathrm{H}, \mathrm{Ar}-\mathrm{H}), 6.99(\mathrm{~s}, 0.65 \times$ IH. Ar-H), 7.16 (s, $0.35 \times 1 H$, Ar-H). Ratio of atropisomers $~ 35 / 65$.

Minor isomer: Colorless crystals, yield $22 \mathrm{mg}$ (2.9\%, de $=96.0 \%$ ). $\mathrm{C}_{32} \mathrm{H}_{39} \mathrm{NO}_{6}$ (533.7) Calc. C $72.0 \mathrm{H} 7.37 \mathrm{~N} 2.6$ Found C $72.1 \mathrm{H} 7.40 \mathrm{~N} 2.5$. Mol. mass 533 (MS) - IR: 1785; 1700; 1640; $1510 \mathrm{~cm}^{-1} .-400 \mathrm{MHz}-{ }^{1} \mathrm{H}$ NMR $\left(\mathrm{CDCl}_{3}\right): 1.04$ (s, 3H, CH$), 1.11\left(\mathrm{~s}, 3 \mathrm{H}, \mathrm{CH}_{3}\right), 1.18\left(\mathrm{~s}, 3 \mathrm{H}, \mathrm{CH}_{3}\right)$, 1.70 (ddd, J 4/9/13 Hz, 1H), 1.92 (ddd, J 4/11/13 Hz, 1H), 2.03 (ddd, J $\sim 4 / 9 / 13 \mathrm{~Hz}, 1 \mathrm{H}), 2.07,2.12$ (2 x s, combined 6H, Ar- $\left.\mathrm{CH}_{3}\right), 2.25(\mathrm{~s}, 3 \mathrm{H}$. Ar- $\mathrm{CH}_{3}$ ), 2.46 (ddd, J 4/1 l/13 Hz, IH), 2.73 (dt, J 16/4 Hz, lH), 2.88 (ddd, J 5/11/16 Hz, 1H), 3.11-3.20 (m, 2H), 3.60 (ddd, J 4/11/14 Hz, 1H), $3.84\left(\mathrm{~s}, 3 \mathrm{H}, \mathrm{OCH}_{3}\right), 3.85\left(\mathrm{~s}, 3 \mathrm{H}, \mathrm{OCH}_{3}\right), 4.47(\mathrm{dt}, \mathrm{J} \sim 14 / 5 \mathrm{~Hz}, 1 \mathrm{H}$, $\mathrm{NCH}_{2} \mathrm{CH}_{2} \mathrm{Ar}$ ), 6.29 (t, J $\left.\sim 5.5 \mathrm{~Hz}, 1 \mathrm{H}, \mathrm{NCHAr}\right), 6.58(\mathrm{~s}, 1 \mathrm{H}, \mathrm{Ar}-\mathrm{H}), 6.79$ $(\mathrm{s}, 2 \mathrm{H}, \mathrm{Ar}-\mathrm{H}), 6.69(\mathrm{~s}, 1 \mathrm{H}, \mathrm{Ar}-\mathrm{H})$. Signals of minor atropisomer of very low intensity.

(IS, 4R)-[(IR)-1,2,3,4-Tetryhydro-6,7-dimethoxy-1-(I,I-dimethyl-2-oxo2-phenyl-1-ethyl)-2-isoquinolylcarbonyl]-4,7,7-trimethyl-2-oxa-bicyclo[2.2.1] heptan-3-one (R)-11b and

(IS,4R)-[(IS)-1,2,3,4-Tetrahydro-6,7-dimethoxy-1-(1,1-dimethyl-2-oxo-2phenyl-1-ethyl)-2-isoquinolylcarbonyl]-4,7,7-trimethyl-2-oxa-bicyclo[2.2.1] heptan-3-one (S)-12b

From $436 \mathrm{mg}(1.32 \mathrm{mmol})$ of 3 in $8 \mathrm{ml}$ of $\mathrm{CH}_{2} \mathrm{Cl}_{2}, 411 \mathrm{mg}$ (1.10 mmol) of 4 in $8 \mathrm{ml}$ of $\mathrm{CH}_{2} \mathrm{Cl}_{2}$ (dilution with $14 \mathrm{ml}$ of $\mathrm{CH}_{2} \mathrm{Cl}_{2}$ prior to addition of 10b) and $364 \mathrm{mg}$ ( $1.65 \mathrm{mmol}$ ) of $10 \mathrm{~b}$ (in $0.2 \mathrm{ml}$ of $\mathrm{CH}_{2} \mathrm{Cl}_{2}$ ) as described for $(R)-8 a /(S)-9 a$, but without $\mathrm{TiCl}_{4}$. Addition of $10 \mathrm{~b}$ at $-78^{\circ} \mathrm{C}$, reaction time $2 \mathrm{~h}$. After aqueous work-up a crude product containing (R)-11b/(S)$12 \mathrm{~b}$ was obtained. Ratio of $(\mathrm{R})-11 \mathrm{~b} /(\mathrm{S})-12 \mathrm{~b}$ determined by $\mathrm{HPLC}\left(\mathrm{SiO}_{2}, \mathrm{n}-\right.$ hexane/ethyl acetate $=75 / 25,2.0 \mathrm{ml} / \mathrm{min}$, minor isomer $7.0 \mathrm{~min}$, major isomer $10.4 \mathrm{~min}$; ratio: Table 2, entry 2). Pure diastereomers were obtained after $C C$ (n-hexane/ethyl acetate $=75 / 25)$.
Major isomer: Colorless crystals, yield $15 \mathrm{mg}(2.6 \%$, de=95.5\%). $\mathrm{C}_{31} \mathrm{H}_{37} \mathrm{NO}_{6}$ (519.6). Mol. mass 519 (MS). - IR: 1790; 1680; 1650; 1510 $\mathrm{cm}^{-1} .-400 \mathrm{MHz}-{ }^{1} \mathrm{H}-\mathrm{NMR}\left(\mathrm{CDCl}_{3}\right): 1.03\left(\mathrm{~s}, 3 \mathrm{H}, \mathrm{CH}_{3}\right), 1.12\left(\mathrm{~s}, 3 \mathrm{H}, \mathrm{CH}_{3}\right.$ ), 1.19 (s, 3H, $\mathrm{CH}_{3}$ ), 1.23 (s, 3H, $\left.\mathrm{CH}_{3}\right), 1.40\left(\mathrm{~s}, 3 \mathrm{H}, \mathrm{CH}_{3}\right), 1.73$ (ddd, J $4 / 9 / 13 \mathrm{~Hz}, 1 \mathrm{H}$ ), 1.90-1.97 (m, 1H), 2.04 (ddd, J 4/9/13 Hz, 1H), 2.41 (ddd, J 4/1 1/13 Hz, 1H), 2.78-2.85 (m, 2H), 3.63 (s, 3H, OCH 3 ), 3.83 (s. $3 \mathrm{H}, \mathrm{OCH}_{3}$ ), 3.74-3.90 (m, lH, party obscured), 4.61 (ddd, unresolved, J $\left.2 / 5 / 14 \mathrm{~Hz}, 1 \mathrm{H}, \mathrm{NCH}_{2} \mathrm{CH}_{2} \mathrm{Ar}\right), 6.35(\mathrm{~s}, 1 \mathrm{H}), 6.55(\mathrm{~s}, 1 \mathrm{H}), 6.72(\mathrm{~s}, 1 \mathrm{H}), 7.44$ $7.52(\mathrm{~m}, 3 \mathrm{H}, \mathrm{Ar}-\mathrm{H}), 8.02-8.04(\mathrm{~m}, 2 \mathrm{H}, \mathrm{Ar}-\mathrm{H})$. Signals of minor atropisomer of very low intensity.

Minor isomer. Colorless crystals, m.p. $174-177^{\circ} \mathrm{C},[\alpha]_{546}=-56.6^{\circ},[\alpha]_{578}$ $=-50.0^{\circ}\left(\mathrm{c}=0.2, \mathrm{CH}_{2} \mathrm{Cl}_{2}\right)$, yield $11 \mathrm{mg}\left(2.0 \%\right.$, de=99.0\%)., $\mathrm{C}_{31} \mathrm{H}_{37} \mathrm{NO}_{6}$ (519.6). Calc. C 71.7 H 7.18 N 2.7 Found C 71.6 H 7.29 N 2.8 Mol. mass 519 (MS). - IR: 1780; 1670;1640;1520 cm-1 - $400 \mathrm{MHz}$ - 'H-NMR $\left(\mathrm{CDCl}_{3}\right): 0.98\left(\mathrm{~s}, 3 \mathrm{H}, \mathrm{CH}_{3}\right), 1.08\left(\mathrm{~s}, 3 \mathrm{H}, \mathrm{CH}_{3}\right), 1.14\left(\mathrm{~s}, 3 \mathrm{H}, \mathrm{CH}_{3}\right), 1.31$ (s, $\left.3 \mathrm{H}, \mathrm{CH}_{3}\right), 1.36\left(\mathrm{~s}, 3 \mathrm{H}, \mathrm{CH}_{3}\right), 1.69$ (ddd, J $\left.\sim 4 / 9 / 13 \mathrm{~Hz}, 1 \mathrm{H}\right), 1.86$ (ddd, J $4 / 11 / 13 \mathrm{~Hz}, 1 \mathrm{H}$ ), 2.01-2.11 (m, 2H), 2.72 (dd, J $~ 3.5 / 17 \mathrm{~Hz}, 1 \mathrm{H}$ ), 3.05 (ddd, J 7/12/17 Hz, 1H), $3.69\left(\mathrm{~s}, 3 \mathrm{H}, \mathrm{OCH}_{3}\right), 3.65-3.75$ (1H, signal obscured), 3.84 (s, $3 \mathrm{H}, \mathrm{OCH}_{3}$ ), 4.50 (dd, $\mathrm{J} \sim 7 / 14 \mathrm{~Hz}, 1 \mathrm{H}, \mathrm{NCH}_{2} \mathrm{CH}_{2} \mathrm{Ar}$ ), 6.44 (s, 1H), $6.51(\mathrm{~s}, 1 \mathrm{H}), 6.57$ (s, 1H), 7.41-7.52 (m, 3H, H-3/4 phenyl), 7.988.00 (m, $2 \mathrm{H}, \mathrm{H}-2$ phenyl).

(IS, 4R)-1-I(IR)-1-(2-Cyclohex-1-enyl-2-oxo-1-ethyl)-1,2,3,4-tetrahydro6,7-dimethoxy-2-isoquinolylcarbonyl]-4,7,7-trimethyl-2-oxa-bicyclo[2.2.1]heptan-3-one $(R)-11 \mathrm{c}$ and

(IS, 4R)-I-I(IS)-1-(2-Cyclohex-1-enyl-2-oxo-1-ethyl)-1,2,3,4-tetrahydro6,7-dimethoxy-2-isoquinolylcarbonyl]-4,7,7-trimethyl-2-oxa-bicyclo[2.2.1] heptan-3-one (S)-12c

From $321 \mathrm{mg}(0.972 \mathrm{mmol})$ of $3 \mathrm{in} 5 \mathrm{ml}$ of $\mathrm{CH}_{2} \mathrm{Cl}_{2}, 303 \mathrm{mg}(0.810$ mmol) of 4 in $5 \mathrm{ml}$ of $\mathrm{CH}_{2} \mathrm{Cl}_{2}$ (12 $\mathrm{ml}$ of $\mathrm{CH}_{2} \mathrm{Cl}_{2}$ for dilution prior to addition of $10 \mathrm{c}$ ) and $191 \mathrm{mg}\left(0.972 \mathrm{mmol}\right.$ ) of $10 \mathrm{C}$ (in $0.1 \mathrm{ml}$ of $\mathrm{CH}_{2} \mathrm{Cl}_{2}$ ) as described for (R)-8a/(S)-9a a), but without $\mathrm{TiCl}_{4}$. Addition of $10 \mathrm{C}$ at $-95^{\circ} \mathrm{C}$, reaction time $1 \mathrm{~h}$. After aqueous work-up a crude product containing (R)$11 \mathrm{c} /(\mathrm{S})-12 \mathrm{c}$ was obtained. Ratio of (R)-11d(S)-12c determined by HPLC (chiral column, $n$-hexahe/isopropanol $=85 / 15,2.0 \mathrm{ml} / \mathrm{min}$, major isomer $15.3 \mathrm{~min}$, minor isomer $18.3 \mathrm{~min}$; ratio: Table 2, entry 3). Pure diastereomers were obtained after repeated CC (n-hexane/ethyl ether $=45 / 55$, the retention of the minor isomer is stronger).

Major isomer: Colorless crystals, m.p. $142-143^{\circ} \mathrm{C},[\alpha]_{546}=-172.9^{\circ}$, $[\alpha]_{578}=-150.5^{\circ}\left(c=1.07, \mathrm{CH}_{3} \mathrm{OH}\right)$, yield $50 \mathrm{mg}(12.4 \%$, de $\geq 98 \%)$. $\mathrm{C}_{29} \mathrm{H}_{37} \mathrm{NO}_{6}$ (495.6) Calc. C 70.3 H 7.52 N 2.8 Found C $70.3 \mathrm{H} 7.53 \mathrm{~N} 2.8$ Mol. mass 495 (MS). - IR: 1780; 1650;1635; $1510 \mathrm{~cm}^{-1}$. $-400 \mathrm{MHz}$ - ${ }^{2} \mathrm{H}$ $\operatorname{NMR}\left(\mathrm{CDCl}_{3}\right): 0.94\left(\mathrm{~s}, 0.8 \times 3 \mathrm{H}, \mathrm{CH}_{3}\right), 0.98\left(\mathrm{~s}, 0.2 \times 3 \mathrm{H}, \mathrm{CH}_{3}\right), 1.07$ (s, $\left.0.2 \times 3 \mathrm{H}, \mathrm{CH}_{3}\right), 1.08\left(\mathrm{~s}, 0.8 \times 3 \mathrm{H}, \mathrm{CH}_{3}\right), 1.17\left(\mathrm{~s}, 0.8 \times 3 \mathrm{H}, \mathrm{CH}_{3}\right), 1.19$ (s, $\left.0.2 \times 3 \mathrm{H}, \mathrm{CH}_{3}\right), 1.56-1.64(\mathrm{~m}, 4 \mathrm{H}), 1.72$ (ddd, $\left.\mathrm{J} \sim 4 / 9 / 13 \mathrm{~Hz}, 1 \mathrm{H}\right), 1.91$ (ddd, J 4/11/13 Hz, 1H), 2.10 (ddd, J 4/9/13 Hz, 1H), 2.20-2.31 (m, 4H), 2.34 (ddd, J 4/11/13 Hz, 1H), 2.69 (dt, J 16/3 Hz, 1H), 2.93 (dd, J $\sim 7 / 13.9 \mathrm{~Hz}, 1 \mathrm{H}$ ), 3.06 (ddd, J 5/11.7/16 Hz, 1H), 3.23 (dd, J 7/13.9 Hz, lH), 3.50 (ddd, J 3/11.7/13 Hz, 1H), 3.814 (s, $0.2 \times 3 \mathrm{H}, \mathrm{OCH}_{3}$ ), 3.832 (s, $\left.0.8 \times 3 \mathrm{H}, \mathrm{OCH}_{3}\right), 3.838\left(\mathrm{~s}, 0.2 \times 3 \mathrm{H}, \mathrm{OCH}_{3}\right), 3.844\left(\mathrm{~s}, 0.8 \times 3 \mathrm{H}, \mathrm{OCH}_{3}\right)$, 4.43 (dddd, $\mathrm{J} \sim 1 / 3 / 5 / 13 \mathrm{~Hz}, 0.8 \times 1 \mathrm{H}, \mathrm{NCH}_{2} \mathrm{CH}_{2} \mathrm{Ar}$, origin of long range coupling could not be ascertained), 4.51 (dddd, $\mathrm{J} \sim 1 / 3 / 5 / 13 \mathrm{~Hz}, 0.2 \times 1 \mathrm{H}$, $\mathrm{NCH}_{2} \mathrm{CH}_{2} \mathrm{Ar}$, origin of long range coupling not ascertained), 5.85 (h, J -7 $\mathrm{Hz}, 1 \mathrm{H}, \mathrm{NCHAr}), 6.58$ (s, $0.2 \times 1 \mathrm{H}, \mathrm{Ar}-\mathrm{H}), 6.58$ (s, $0.8 \times 1 \mathrm{H}, \mathrm{Ar}-\mathrm{H}), 6.65$ (s. $0.8 \times 1 \mathrm{H}, \mathrm{Ar}-\mathrm{H}), 6.82(\mathrm{~s}, 0.2 \times 1 \mathrm{H}, \mathrm{Ar}-\mathrm{H}), 6.90$ (t, unresolved, $0.2 \times 1 \mathrm{H}$, $\mathrm{H}$-alkene), 6.94 (t, unresolved, $0.8 \times 1 \mathrm{H}, \mathrm{H}$-alkene). Ratio of atropisomers $\sim$ 2/8.

Minor isomer: Colorless crystals, yield $9 \mathrm{mg}(2.2 \%$, de $=98.4 \%)$. - $\mathrm{C}_{29} \mathrm{H}_{37} \mathrm{NO}_{6}$ (495.6). Mol. mass 495 (MS) - IR: 1780; 1660; 1640; 1510 $\mathrm{cm}^{-1} .-400 \mathrm{MHz}-{ }^{1} \mathrm{H}-\mathrm{NMR}\left(\mathrm{CDCl}_{3}\right): 1.04\left(\mathrm{~s}, 0.8 \times 3 \mathrm{H}, \mathrm{CH}_{3}\right), 1.08(\mathrm{~s}, 0.2$ $\left.\times 3 \mathrm{H}, \mathrm{CH}_{3}\right), 1.09\left(\mathrm{~s}, 0.2 \times 3 \mathrm{H}, \mathrm{CH}_{3}\right), 1.10\left(\mathrm{~s}, 0.8 \times 3 \mathrm{H}, \mathrm{CH}_{3}\right), 1.11(\mathrm{~s}, 0.8 \times$ $\left.3 \mathrm{H}, \mathrm{CH}_{3}\right), 1.20$ (s, $\left.0.2 \times 3 \mathrm{H}, \mathrm{CH}_{3}\right), 1.56-1.70(\mathrm{~m}, 5 \mathrm{H}), 1.88$ (ddd, J $4 / 11 / 13 \mathrm{~Hz}, 1 \mathrm{H}$ ), 1.98 (ddd, J 4/9/13 Hz, 1H), 2.23-2.27 (m, 4H), 2.45 
(ddd. J 4/1 1/13 Hz, 1H), 2.73 (dt, J 16/3 Hz, 1H), 2.89 (ddd, J 5/11/16 $\mathrm{Hz}, 1 \mathrm{H}$ ), 3.03 (dd, J 5.8/14.5 Hz, 1H), 3.10 (dd, J 7.5/14.5 Hz, lH), 3.60 (ddd, J 3/11/14 Hz, 1H), 3.83, 3.84 ( $2 \times \mathrm{s}$, combined $6 \mathrm{H}, 2 \times \mathrm{OCH}_{3}$ ), 4.54 (ddd, J $\sim 3 / 5 / 14 \mathrm{~Hz}, 0.8 \times 1 \mathrm{H}, \mathrm{NCH}_{2} \mathrm{CH}_{2} \mathrm{Ar}$ ), 4.62 (ddd, unresolved, $0.2 \times 1 \mathrm{H}, \mathrm{NCH}_{2} \mathrm{CH}_{2} \mathrm{Ar}$ ), 6.02 (pseudo $\mathrm{L} \mathrm{J} \sim 6-7 \mathrm{~Hz}, 0.8 \times 1 \mathrm{H}, \mathrm{NCHAr}$ ), $6.10(\mathrm{~m}, 0.2 \times 1 \mathrm{H}, \mathrm{NCHAr}), 6.57(\mathrm{~s}, 1 \mathrm{H}, \mathrm{Ar}-\mathrm{H}), 6.67(\mathrm{~s}, 1 \mathrm{H}, \mathrm{Ar}-\mathrm{H}), 6.84(\mathrm{t}$, unresolved, $0.2 \times 1 \mathrm{H}, \mathrm{H}$-alkene), 6.90 (t, unresolved, $0.8 \times 1 \mathrm{H}, \mathrm{H}$-alkene). Ratio of atropisomers $\sim 2 / 8$.

(IS, 4R)-1-[(IR)-1-(3,3-Dimethyl-2-oxo-1-butyl)-1,2,3,4-tetrahydro-6,7. dimethoxy-2-isoquinolylcarbonyl]-4,7,7-trimethyl-2-oxa-bicyclo[2.2.1]heptan-3-one (R)-11d and

(IS, 4R)-1-[(IS)-1-(3,3-Dimethyl-2-axo-1-butyl)-1, 2,3,4-letrahydro-6,7. dimethoxy-2-isoquinolylcarbonyl]-4,7,7-trimethyl-2-oxa-bicyclo[2.2.1]heptan-3-one (S)-12d

a) From $110 \mathrm{mg}(0.333 \mathrm{mmol})$ of 3 in $1.5 \mathrm{ml}$ of $\mathrm{CH}_{2} \mathrm{Cl}_{2}, 104 \mathrm{mg}(0.277$ mmol) of 4 in $1.5 \mathrm{ml}$ of $\mathrm{CH}_{2} \mathrm{Cl}_{2}\left(4 \mathrm{ml}\right.$ of $\mathrm{CH}_{2} \mathrm{Cl}_{2}$ for dilution prior to addition of $10 \mathrm{~d}$ ) and $57 \mathrm{mg}(0.333 \mathrm{mmol})$ of $10 \mathrm{~d}$ (in $0.15 \mathrm{ml}$ of $\mathrm{CH}_{2} \mathrm{Cl}_{2}$ ) as described for $(\mathrm{R})-8 \mathrm{a} /(\mathrm{S})-9 \mathrm{a}$ a). For reaction conditions and ratio of diastereomers (determined from the crude product by HPLC $\mathrm{SiO}_{2}, \mathrm{n}$-hexane/ethyl ether $=6 / 4,2.0 \mathrm{ml} / \mathrm{min}$, major isomer $14.2 \mathrm{~min}$, minor isomer $17.0 \mathrm{~min}$ ): Table 2, entry 4 .

b) From $1.23 \mathrm{~g}(3.72 \mathrm{mmol})$ of 3 in $18 \mathrm{ml}$ of $\mathrm{CH}_{2} \mathrm{Cl}_{2}, 1.16 \mathrm{~g}(3.10 \mathrm{mmol})$ of 4 in $18 \mathrm{ml}$ of $\mathrm{CH}_{2} \mathrm{Cl}_{2}\left(40 \mathrm{ml}\right.$ of $\mathrm{CH}_{2} \mathrm{Cl}_{2}$ for dilution prior to addition of $10 \mathrm{~d}$ ) and $642 \mathrm{mg}\left(3.72 \mathrm{mmol}\right.$ ) of $10 \mathrm{~d}$ (in $1 \mathrm{ml}$ of $\mathrm{CH}_{2} \mathrm{Cl}_{2}$ ) as described under a) according Table 2 , entry 5 . The major isomer was obtained in a yield of $30.9 \%$ after $\mathrm{CC}$.

c) From $85 \mathrm{mg}(0.258 \mathrm{mmol})$ of 3 in $1.5 \mathrm{ml}$ of $\mathrm{CH}_{2} \mathrm{Cl}_{2}, 80 \mathrm{mg}(0.215$ mmol) of 4 in $1.5 \mathrm{ml}$ of $\mathrm{CH}_{2} \mathrm{Cl}_{2}\left(3 \mathrm{ml}\right.$ of $\mathrm{CH}_{2} \mathrm{Cl}_{2}$ for dilution prior to addition of $10 \mathrm{~d}), 41 \mathrm{mg}(0.215 \mathrm{mmol})$ of $\mathrm{TiCl}_{4}$ and $45 \mathrm{mg}(0.258$ mmol) of $10 \mathrm{~d}$ (in $0.15 \mathrm{ml}$ of $\mathrm{CH}_{2} \mathrm{Cl}_{2}$ ) as described under a) according Table 2, entry 6.

d) From $92 \mathrm{mg}(0.278 \mathrm{mmol})$ of $3 \mathrm{in} 1.7 \mathrm{ml}$ of $\mathrm{CH}_{2} \mathrm{Cl}_{2}, 87 \mathrm{mg}(0.232$ mmol) of 4 in $1.7 \mathrm{ml}$ of $\mathrm{CH}_{2} \mathrm{Cl}_{2}\left(2 \mathrm{ml}\right.$ of $\mathrm{CH}_{2} \mathrm{Cl}_{2}$ for dilution prior to addition of $10 \mathrm{~d}), 44 \mathrm{mg}(0.232 \mathrm{mmol})$ of $\mathrm{TiCl}_{4}$ and $48 \mathrm{mg}(0.278$ mmol) of $10 d$ (in $0.15 \mathrm{ml}$ of $\mathrm{CH}_{2} \mathrm{Cl}_{2}$ ) as described under a) according Table 2, entry 7.

Pure diastereomers were obtained after CC (n-hexane/ethyl ether = 4/6).

Major isomer: Colorless crystals, m.p. $143-144^{\circ} \mathrm{C},[\alpha]_{546}=-145.9^{\circ}$ $[\alpha]_{578}=-127.1^{\circ}\left(c=0.42, \mathrm{CH}_{3} \mathrm{OH}\right)$, yield $38 \mathrm{mg}(34.9 \%$, de $>99.5 \%)$. - $\mathrm{C}_{27} \mathrm{H}_{37} \mathrm{NO}_{6}$ (471.6) Calc. C 68.8 H 7.91 N 3.0 Found C 68.7 H 7.71 N 3.0. Mol. mass 471 (MS). - IR: 1780;1690;1630;1520 $\mathrm{cm}^{-1} .-400$ $\mathrm{MHz}-{ }^{\prime} \mathrm{H}-\mathrm{NMR}\left(\mathrm{CDCl}_{3}\right): 0.95\left(\mathrm{~s}, 0.75 \times 3 \mathrm{H}, \mathrm{CH}_{3}\right), 0.98(\mathrm{~s}, 0.25 \times 3 \mathrm{H}$, $\left.\mathrm{CH}_{3}\right), 1.06\left(\mathrm{~s}, 0.25 \times 3 \mathrm{H}, \mathrm{CH}_{3}\right), 1.09\left(\mathrm{~s}, 0.75 \times 3 \mathrm{H}, \mathrm{CH}_{3}\right), 1.13(\mathrm{~s}, 9 \mathrm{H}$, $\left.\mathrm{C}\left(\mathrm{CH}_{3}\right)_{3}\right), 1.18\left(\mathrm{~s}, 0.75 \times 3 \mathrm{H}, \mathrm{CH}_{3}\right), 1.19\left(\mathrm{~s}, 0.25 \times 3 \mathrm{H}, \mathrm{CH}_{3}\right), 1.72$ (ddd, J 4/9/13 Hz, IH), 1.92 (ddd, J 4/11/13 Hz, 1H), 2.12 (ddd, J $4 / 9 / 13 \mathrm{~Hz}, 1 \mathrm{H}$ ), 2.38 (ddd, J 4/11/13 Hz, 1H), 2.66-2.75 (m, 2H), 3.00-3.16 ( $\mathrm{m}, 2 \mathrm{H}), 3.49$ (ddd, J $-4 / 11 / 13 \mathrm{~Hz}, 1 \mathrm{H}), 3.80,3.82,3.84(3 \mathrm{x}$ s, combined $6 \mathrm{H}, 2 \times \mathrm{OCH}_{3}$ ), 4.46 (ddd, $\mathrm{J} \sim 3 / 6 / 13 \mathrm{~Hz}, 0.75 \times 1 \mathrm{H}$, $\left.\mathrm{NCH}_{2} \mathrm{CH}_{2} \mathrm{Ar}\right), 4.50-4.55\left(\mathrm{~m}, 0.25 \times 1 \mathrm{H}, \mathrm{NCH}_{2} \mathrm{CH}_{2} \mathrm{Ar}\right), 5.80-5.85$ (m, $0.25 \times 1 \mathrm{H}, \mathrm{NCHAr}), 5.90(\mathrm{t}, \mathrm{J} \sim 6.5 \mathrm{~Hz}, 0.75 \times 1 \mathrm{H}, \mathrm{NCHAr}), 6.58(\mathrm{~s}$, 1H, Ar-H), 6.65 (s, $0.75 \times 1 \mathrm{H}$, Ar-H), $6.92(\mathrm{~s}, 0.25 \times 1 \mathrm{H}, \mathrm{Ar}-\mathrm{H})$. Ratio of atropisomers $\sim 25 / 75$.

Minor isomer. Colorless crystals. $8 \mathrm{mg}(7.6 \%$; de $=85 \%)$. $-\mathrm{C}_{27} \mathrm{H}_{37} \mathrm{NO}_{6}$ (471.6) Mol. mass 471 (MS). - IR: 1790; 1710; 1640; $1520 \mathrm{~cm}^{-1}$. - 400 $\mathrm{MHz}-{ }^{1} \mathrm{H}-\mathrm{NMR}\left(\mathrm{CDCl}_{3}\right): 1.07,1.08,1.11,1.13,1.14(5 \times \mathrm{s}$, combined $18 \mathrm{H}, 6 \times \mathrm{CH}_{3}$ ), 1.66 (ddd, J $\sim 4 / 9 / 13 \mathrm{~Hz}, 1 \mathrm{H}$ ), 1.91 (ddd, J 4/1 I/13 $\mathrm{Hz}, 1 \mathrm{H}$ ), 1.99 (ddd, J $\sim 4 / 9 / 13 \mathrm{~Hz}, 1 \mathrm{H}$ ), 2.45 (ddd, J 4/11/13 Hz, $1 \mathrm{H}$ ), 2.74 (di, J 16/4 Hz, 1H), 2.84-2.99 (m, 3H), 3.60 (ddd, J 4/11/14 $\mathrm{Hz}, 1 \mathrm{H}), 3.79,3.82,3.84$ ( $3 \times \mathrm{s}$, combined $\left.6 \mathrm{H}, 2 \times \mathrm{OCH}_{3}\right), 4.51$ (ddd, J 3/4/14 Hz, 0.75 x 1H, NCH $\left.\mathrm{CH}_{2} \mathrm{Ar}\right), 4.57-4.64(\mathrm{~m}, 0.25 \times 1 \mathrm{H}$, $\left.\mathrm{NCH}_{2} \mathrm{CH}_{2} \mathrm{Ar}\right), 6.07(\mathrm{~h} \mathrm{~J}-6.5 \mathrm{~Hz}, 1 \mathrm{H}, \mathrm{NCHAr}), 6.57(\mathrm{~s}, 1 \mathrm{H}, \mathrm{Ar}-\mathrm{H})$, $6.66(\mathrm{~s}, \mathrm{lH}, \mathrm{Ar}-\mathrm{H})$. Ratio of atropisomers $\sim 75 / 25$.
(IS, 4R)-1-1(IR)-1,2,3,4-Tetrahydro-6,7-dimethoxy-1-(2-oxo-1-ethyl)-2. isoquinolylcarbonyl]-4,7,7-trimethyl-2-oxa-bicyclo/2.2.1 heptan-3-one (R)-11e and (IS, 4R)-1-1(1S)-1,2,3,4-Tetrahydro-6,7-dimethoxy-1. (2-oxo-1-ethyl)-2-isoquinolylcarbonyl]-4,7,7-trimethyl-2-oxa-bicyclo[2.2.1] heptan-3-one (S)-12e

From $96 \mathrm{mg}(0.290 \mathrm{mmol})$ of 3 in $1.5 \mathrm{ml}$ of $\mathrm{CH}_{2} \mathrm{Cl}_{2}, 90 \mathrm{mg}(0.242$ mmol) of 4 in $1.5 \mathrm{ml}$ of $\mathrm{CH}_{2} \mathrm{Cl}_{2}$ ( $3 \mathrm{ml}$ of $\mathrm{CH}_{2} \mathrm{Cl}_{2}$ for dilution prior to addition of $10 \mathrm{e})$ and $46 \mathrm{mg}(0.290 \mathrm{mmol})$ of $10 \mathrm{e}$ as described for $(\mathrm{R})-8 \mathrm{a} /(\mathrm{S})-9 \mathrm{a}$ a), but without $\mathrm{TiCl}_{4}$. Addition of $10 \mathrm{e}$ at $-19^{\circ} \mathrm{C}$, reaction time $6 \mathrm{~h}$. After aqueous work-up and $\mathrm{CC}\left(\mathrm{SiO}_{2}, \mathrm{n}\right.$-hexane/ethyl acetate $\left.=7 / 3\right)$ a mixture of (R)-11e/(S)-12e was obtained. As the diastereomers were inseparable on $\mathrm{SiO}_{2}$, the ratio of $(\mathrm{R})-11 \mathrm{e} /(\mathrm{S})-12 \mathrm{e}$ was determined from a purified sample by ${ }^{1} \mathrm{H}$-NMR: Table 2 , entry $8.400 \mathrm{MHz}-{ }^{1} \mathrm{H}-\mathrm{NMR}\left(\mathrm{CDCl}_{2} \mathrm{CDCl}_{2}\right.$, mixture of diastereomers): $0.93,0.96,0.99,1.07,1.09,1.16,1.18,1.24$ (8 x s, combined $\left.9 \mathrm{H}, 3 \times \mathrm{CH}_{3}\right), 1.66-1.72(\mathrm{~m}, 1 \mathrm{H}), 1.87-1.97(\mathrm{~m}, 1 \mathrm{H}), 2.00-2.12(\mathrm{~m}$. IH), 2.21-2.33 (m, IH), 2.64-3.09 (m, 4H), 3.33-3.42 (m, 1H), 3.820, 3.824 ( $2 \times \mathrm{s}$, comb. 6H, $\left.2 \times \mathrm{OCH}_{3}\right), 4.40-4.50,4.50-4.57,4.57-4.65$ (3 x m, comb. $\left.1 \mathrm{H}, \mathrm{NCH}_{2}\right), 5.78(\mathrm{t}, \mathrm{J}=6 \mathrm{~Hz}), 5.87(\mathrm{dd}, \mathrm{J}=4 / 9 \mathrm{~Hz}), 6.06(\mathrm{dd}, \mathrm{J}=4 / 10 \mathrm{~Hz}$, 5.78-6.06 comb. $1 \mathrm{H}, \mathrm{NCH}), 6.58,6.59,6.66$ (3 x s, comb. $2 \mathrm{H}, \mathrm{Ar}-\mathrm{H}), 9.79$ (dd, $\mathrm{J}=2 / 4 \mathrm{~Hz}$ ), 9.82 (dd, $\mathrm{J}=2 / 4 \mathrm{~Hz}), 9.91(\mathrm{~h} \mathrm{~J}=2 \mathrm{~Hz}, 9.79-9.91$ comb. $1 \mathrm{H}, \mathrm{CHO}$ ). The signals reported arise from configurational and rotational isomers.

(IS, 4R)-1-I(IR)-1-(2-Ethoxy-2-oxo-1-ethyl)-1,2,3,4-tetrahydro-6,7dimethoxy-2-isoquinolylcarbonyl]-4,7,7-trimethyl-2-oxa-bicyclo[2.2.1]heptan-3-one (R)-11f and (IS, 4R)-I-[(IS)-I-(2-Ethoxy-2-oxo-1-ethyl)1,23,4-tetrahydro-6,7-dimethoxy-2-isoquinolylcarbonyl]-4,7,7trimethyl-2-oxa-bicyclo[2.2.1]heptan-3-one(S)-12f

From $98 \mathrm{mg}(0.295 \mathrm{mmol})$ of 3 in $1.5 \mathrm{ml}$ of $\mathrm{CH}_{2} \mathrm{Cl}_{2}, 92 \mathrm{mg}(0.246$ mmol) of 4 in $1.5 \mathrm{ml}$ of $\mathrm{CH}_{2} \mathrm{Cl}_{2}$ (3.5 ml of $\mathrm{CH}_{2} \mathrm{Cl}_{2}$ for dilution prior to addition of 10 ) and $394 \mathrm{mg}(2.46 \mathrm{mmol})$ of $10 \mathrm{r}$ as described for $(\mathrm{R})-8 \mathrm{a} /(\mathrm{S})$ 9a a), but without $\mathrm{TiCl}_{4}$. Addition of 10 at room temp., reaction time 11 days. After aqueous work-up and $\mathrm{CC}$ (n-hexane/ethyl ether $=1 / 1$ ) a mixture of diastereomers was obtained. The isomers were inseparable on $\mathrm{SiO}_{2}$. The ratio (R)-11f/(S)-12f was determined on a chiral column by HPLC from the crude product ( $n$-hexane/isopropanol $=8 / 2,2.0 \mathrm{ml} / \mathrm{min}$, major isomer $7.7 \mathrm{~min}$, minor isomer $10.4 \mathrm{~min}$; ratio: Table 2, entry 9). The physical data given below refer to the mixture of diastereomers obtained: Colorless crystals $[\alpha]_{546}=-9.6^{\circ},[\alpha]_{578}=-9.6^{\circ}\left(c=0.41, \mathrm{CH}_{3} \mathrm{OH}\right)$. - m.p. $60-67^{\circ} \mathrm{C}$, yield $50 \mathrm{mg}(43.8 \%)$. - $\mathrm{C}_{25} \mathrm{H}_{33} \mathrm{NO}$ (459.5) Calc. C $65.3 \mathrm{H} 7.23$ N 3.1 Found C 65.3 H 7.04 N 3.2. Mol. mass 459 (MS). - IR: 1785; 1730; $1640 ; 1510 \mathrm{~cm}^{-1}$. For analytical purpose a sample of (R)-11//(S)-12f was separated on a chiral column ( $n$-hexane/isopropanol $=7 / 3$; order of elution: 1. major isomer, 2. minor isomer).

Major isomer. $400 \mathrm{MHz}-{ }^{1} \mathrm{H}-\mathrm{NMR}\left(\mathrm{CDCl}_{3}\right): 0.96\left(\mathrm{~s}, 0.8 \times 3 \mathrm{H}, \mathrm{CH}_{3}\right)$, $1.01\left(\mathrm{~s}, 0.2 \times 3 \mathrm{H}, \mathrm{CH}_{3}\right), 1.09\left(\mathrm{~s}, 3 \mathrm{H}, \mathrm{CH}_{3}\right), 1.19\left(\mathrm{~s} ; 0.8 \times 3 \mathrm{H}, \mathrm{CH}_{3}\right), 1.21(\mathrm{~s}$, $\left.0.2 \times 3 \mathrm{H}, \mathrm{CH}_{3}\right), 1.28\left(\mathrm{t}, \mathrm{J}=7.2 \mathrm{~Hz}, 3 \mathrm{H}, \mathrm{CH}_{2} \mathrm{CH}_{3}\right), 1.74$ (ddd, $\mathrm{J} \sim 4 / 9 / 13 \mathrm{~Hz}$, 1H), 1.93 (ddd, J 4/11/13 Hz, 1H), 2.14 (ddd, J 4/9/13 Hz, 1H), 2.36 (ddd, $\mathrm{J} \sim 4 / 11 / 13 \mathrm{~Hz}, 1 \mathrm{H}), 2.66-2.70(\mathrm{~m}, 1 \mathrm{H}), 2.71-2.80(\mathrm{~m}, 0.8 \times 2 \mathrm{H}$ ), 2.87-2.91 (m, $0.2 \times 2 \mathrm{H}$ ), 3.08 (ddd, J $\sim 4 / 11 / 16 \mathrm{~Hz}, 1 \mathrm{H}$ ), 3.47 (ddd, J $4 / 11 / 13 \mathrm{~Hz}, \mathrm{IH}), 3.84,3.85\left(2 \times \mathrm{s}\right.$, combined $\left.6 \mathrm{H}, 2 \times \mathrm{OCH}_{3}\right), 4.12(\mathrm{q}, \mathrm{J}=$ $7.2 \mathrm{~Hz}, 2 \mathrm{H}, \mathrm{CH}_{2} \mathrm{CH}_{3}$ ), 4.48 (dd, unresolved, J $\sim 4 / 13 \mathrm{~Hz}, 0.8 \times 1 \mathrm{H}$; $\mathrm{NCH}_{2} \mathrm{CH}_{2} \mathrm{Ar}$ ), 4.55-4.62 (m, $0.2 \times 1 \mathrm{H}, \mathrm{NCH}_{2} \mathrm{CH}_{2} \mathrm{Ar}$ ), 5.72 (t, unresolved, $0.2 \times 1 \mathrm{H}, \mathrm{NCHAr}$ ), 5.87 (pseudo $\mathrm{t}, \mathrm{J} \sim 6$ and $8 \mathrm{~Hz}$, respectively, $0.8 \times 1 \mathrm{H}$, NCHAr), 6.59 (s, 1H, Ar-H), 6.67 (s, $0.8 \times 1 \mathrm{H}, \mathrm{Ar}-\mathrm{H}), 6.80$ (s, $0.2 \times 1 \mathrm{H}$, Ar-H). Ratio of atropisomers $\sim 2 / 8$.

Minor isomers: $400 \mathrm{MHz}$ - ${ }^{1} \mathrm{H}-\mathrm{NMR}\left(\mathrm{CDCl}_{3}\right): 1.07\left(\mathrm{~s}, 3 \mathrm{H}, \mathrm{CH}_{3}\right), 1.12(\mathrm{~s}$, $6 \mathrm{H}, 2 \times \mathrm{CH}_{3}$ ), $1.28\left(\mathrm{t}, \mathrm{J} \sim 7 \mathrm{~Hz}, 3 \mathrm{H}, \mathrm{CH}_{2} \mathrm{CH}_{3}\right.$ ), 1.67 (ddd, J $\sim 4 / 9 / 13 \mathrm{~Hz}$, $1 \mathrm{H}$ ), 1.90 (ddd, J 4/11/13 Hz, 1H), 1.99 (ddd, J 4/9/13 Hz, 1H), 2.50 (ddd, J 4/11/13 Hz, 1H), 2.71-2.87 (m, 3H), 2.92 (ddd, J 5/11.5/16 Hz, 1H), 3.55 (ddd, J 4/11.5/14 Hz, 1H), 3.84, 3.85 ( 2 x s, combined $6 \mathrm{H}, 2 \mathrm{x}$ $\mathrm{OCH}_{3}$ ), 4.12 (pseudo dq, J $\sim 1 / 7 \mathrm{~Hz}, \mathrm{ABX}_{3}$ pattem, $2 \mathrm{H}, \mathrm{CH}_{2} \mathrm{CH}_{3}$ ), 4.60 
(ddd, J 4/5/14 Hz, 1H, $\mathrm{NCH}_{2} \mathrm{CH}_{2} \mathrm{Ar}$ ), 6.01 (1, J $\sim 7 \mathrm{~Hz}, 1 \mathrm{H}, \mathrm{NCHAr}$ ), $6.58(\mathrm{~s}, 1 \mathrm{H}, \mathrm{Ar}-\mathrm{H}), 6.68(\mathrm{~s}, 1 \mathrm{H}, \mathrm{Ar}-\mathrm{H})$. Because of their low intensity the signals of the minor atropisomer have been omitted.

\section{Hydrogenation of Amido Ketones $(R)-8 /(S)-9$}

(IS, 4R)-1-I(IR)-1 23.4-Tetrahydro-6,7-dimethoxy-1-(2-phenyl-1-ethyl)2-isoquinolylcarbonyl]-4,7,7-trimethyl-2-oxa-bicyclo[2.2.1/heptan-3-one (R)-13a. (IS, 4R)-1-(IS)-1,23.4-Tetrahydro-6,7-dimethoxy-1-(2-phenyll-ethyl)-2-isoquinolylcarbonyl]-4,7.7-trimethyl-2-oxa-bicyclo(2.2.I] heptan3-one (S)-14a and (IS,4R)-1-I(IR)-1-(2-Cyclohexyl-1-ethyl)1,2,3,4-ietrahydro-6,7-dimethoxy-isoquinolylcarbonyl]-4,7,7-trimethyl. 2-oxa-bicyclo[2.2.1]heptan-3-one $(R)-15$

To a solution of $1.50 \mathrm{~g}(3.05 \mathrm{mmo})$ of a mixture of diastereomers of $(R)$ $8 \mathrm{a} /(\mathrm{S})-9 \mathrm{a}(82.4 / 17.6)$ in $50 \mathrm{ml}$ of glacial acetic acid, $\mathrm{CF}_{3} \mathrm{CO}_{2} \mathrm{H}(0.5 \mathrm{ml})$ and Pd/C (632 mg, 10\% Pd) were added. The mixture was hydrogenated at room temp. at 3 bar for $24 \mathrm{~h}$. Pd/C was filtered off and the filtrate concentrated in vacuo. The residue was dissolved in ethyl ether. The etheral solution was washed with salurated $\mathrm{NaCl}$-solution $(3 \mathrm{x})$, dried over $\mathrm{MgSO}_{4}$ and the solvent was evaporated in vacuo. The residue containing (R)-13a/(S)14a (ratio determined by $\mathrm{HPLC}$ on $\mathrm{SiO}_{2}$ with $n$-hexane/ethyl acetate $=7 / 3$ : Table 4, entry 1) was separated by repeated column and radial chromatography (n-hexane/ethyl acetate $=7 / 3$ ). Thereby also $(\mathrm{R})-15$ was obtained (order of elution: 1. (R)-15 2. (R)-13a 3. (S)-14a).

(R)-13a: Colorless crystals, m.p. $163-164^{\circ} \mathrm{C},[\alpha]_{546}=-140.2^{\circ},[\alpha]_{578}=$ $-119.6^{\circ}\left(\mathrm{c}=0.54, \mathrm{CH}_{3} \mathrm{OH}\right)$, yield $861 \mathrm{mg}(59.1 \%$, de $>99.5 \%)$. $\mathrm{C}_{29} \mathrm{H}_{35} \mathrm{NO}_{5}$ (477.6) Calc. C 72.9 H 7.38 N 2.9 Found C 72.9 H 7.29 N 3.0 Mol.mass 477 (MS). - IR: 1785; 1640; $1510 \mathrm{~cm}^{-1}$. $-400 \mathrm{MHz}$ - ${ }^{1} \mathrm{H}-\mathrm{NMR}\left(\mathrm{CDCl}_{3}\right)$ : $0.98\left(\mathrm{~s}, 0.7 \times 3 \mathrm{H}, \mathrm{CH}_{3}\right), 1.07\left(\mathrm{~s}, 0.3 \times 3 \mathrm{H}, \mathrm{CH}_{3}\right), 1.10\left(\mathrm{~s}, 0.7 \times 3 \mathrm{H}, \mathrm{CH}_{3}\right)$, $1.12\left(\mathrm{~s}, 0.3 \times 3 \mathrm{H}, \mathrm{CH}_{3}\right), 1.23\left(\mathrm{~s}, 0.7 \times 3 \mathrm{H}, \mathrm{CH}_{3}\right), 1.24\left(\mathrm{~s}, 0.3 \times 3 \mathrm{H}, \mathrm{CH}_{3}\right)$, 1.75 (đdd, J 4/9/13 Hz, lH), 1.83-2.02 (m, 1H), 2.09-2.19 (m, 3H), 2.38 (ddd, J 4/11/13 Hz, IH), 2.59-2.72 (m, 2H), 2.84 (ddd, J 5/11/14 Hz, $0.7 \times 1 \mathrm{H}$ ), 2.95-3.00 (m, $0.3 \times 1 \mathrm{H}$ ), 3.11 (ddd, J $\sim 5 / 12 / 16 \mathrm{~Hz}, 1 \mathrm{H}$ ), 3.19 (ddd, J 5/12/13 Hz, $0.3 \times 1 \mathrm{H}$ ), 3.48 (ddd, J $\sim 4 / 12 / 13 \mathrm{~Hz}, 0.7 \times 1 \mathrm{H}$, $\mathrm{NCH}_{2} \mathrm{CH}_{2} \mathrm{Ar}$ ), 3.83, 3.84, 3.86 (3 x s, comb. $6 \mathrm{H}, 2 \times \mathrm{OCH}_{3}$ ), 4.47 (dd, J $\left.5 / 13 \mathrm{~Hz}, 0.7 \times 1 \mathrm{H}, \mathrm{NCH}_{2} \mathrm{CH}_{2} \mathrm{Ar}\right), 4.50-4.55\left(\mathrm{~m}, 0.3 \times 1 \mathrm{H}, \mathrm{NCH}_{2} \mathrm{CH}_{2} \mathrm{Ar}\right)$, $5.45(\mathrm{t}, \mathrm{J} \sim 7 \mathrm{~Hz}, 0.3 \times 1 \mathrm{H}, \mathrm{NCHAr}$ ), 5.65 (dd, J $\sim 5 / 9 \mathrm{~Hz}, 0.7 \times 1 \mathrm{H}$, NCHAr), $6.56(\mathrm{~s}, 0.3 \times 2 \mathrm{H}, \mathrm{Ar}-\mathrm{H}), 6.58(\mathrm{~s}, 0.7 \times 2 \mathrm{H}, \mathrm{Ar}-\mathrm{H}), 7.14-7.29(\mathrm{~m}$, $5 \mathrm{H}, \mathrm{C}_{6} \mathrm{H}_{5}$ ). Ratio of atropisomers $\sim 3 /$.

(S)-14a: Colorless crystals, m.p. $152-154^{\circ} \mathrm{C},[\alpha]_{546}=+134.6^{\circ},[\alpha]_{578}=$ $+121.2^{\circ}\left(\mathrm{c}=0.52, \mathrm{CH}_{3} \mathrm{OH}\right)$, yield $127 \mathrm{mg}(8.7 \%$, de $>99.5 \%) .-\mathrm{C}_{29} \mathrm{H}_{35} \mathrm{NO}_{5}$ (477.6) Calc. C 72.9 H 7.38 N 2.9 Found C 72.8 H 7.36 N 2.9. Mol.mass 477 (MS). - IR: 1780; 1620; $1510 \mathrm{~cm}^{-1}$. $400 \mathrm{MHz}$ - ${ }^{1} \mathrm{H}-\mathrm{NMR}\left(\mathrm{CDCl}_{3}\right)$ : 1.09 (s, 3H, $\mathrm{CH}_{3}$ ), 1.13 (s, 3H, $\left.\mathrm{CH}_{3}\right), 1.19$ (s, 3H, $\left.\mathrm{CH}_{3}\right), 1.73$ (ddd, J $4 / 9 / 13 \mathrm{~Hz}, 1 \mathrm{H}$ ), 1.94 (ddd, J 4/11/13 Hz, 1H), 2.02-2.19 (m, 3H), 2.46 (ddd, J 4/11/13 Hz, 1H), 2.63 (ddd, J 5/1 1/13 Hz, 1H), 2.71-2.77 (m, 2H), 2.90 (ddd, $J \sim 5 / 12 / 16.5 \mathrm{~Hz}, 1 \mathrm{H}$ ), 3.57 (ddd, J $\sim 4 / 12 / 14 \mathrm{~Hz}, 1 \mathrm{H}$, $\mathrm{NCH}_{2} \mathrm{CH}_{2} \mathrm{Ar}$ ), 3.82 (s, $3 \mathrm{H}, \mathrm{OCH}_{3}$ ), 3.84 (s, 3H, $\mathrm{OCH}_{3}$ ), 4.64 (dd, J 5/14 $\mathrm{Hz}, 1 \mathrm{H}, \mathrm{NCH}_{2} \mathrm{CH}_{2} \mathrm{Ar}$ ), 5.74 (dd, J $-5 / 9.9 \mathrm{~Hz}, 1 \mathrm{H}, \mathrm{NCHAr}$ ), 6.55, 6.56, $6.59(3 \times$ s, combined $2 \mathrm{H}, \mathrm{Ar}-\mathrm{H}), 7.16-7.20\left(\mathrm{~m}, 3 \mathrm{H}, \mathrm{H}-2 / 4 \mathrm{C}_{6} \mathrm{H}_{5}\right), 7.21-7.30$ $\left(\mathrm{m}, 2 \mathrm{H}, \mathrm{H} \cdot 3, \mathrm{C}_{6} \mathrm{H}_{5}\right)$. Because of their low intensity the signals of the minor atropisomer have been omitted.

(R).15: Colorless crystals, m.p. $180-182^{\circ} \mathrm{C},[\alpha]_{546}=-130.1^{\circ},[\alpha]_{578}=-$ $112.6^{\circ}\left(\mathrm{c}=0.51 . \mathrm{CH}_{3} \mathrm{OH}\right)$, yield $103 \mathrm{mg}(7.0 \%) .-\mathrm{C}_{29} \mathrm{H}_{41} \mathrm{NO}_{5}$ (483.7) Calc. C 72.0 H 8.54 N 2.9 Found C 72.1 H 8.53 N 2.8. Mol. mass 483 (MS). IR: $1780 ; 1640 ; 1520 \mathrm{~cm}^{-1}$. - $400 \mathrm{MHz}$ - ${ }^{1} \mathrm{H}-\mathrm{NMR}\left(\mathrm{CDCl}_{3}\right): 0.88-0.93(\mathrm{~m}$, $2 \mathrm{H}), 0.96\left(\mathrm{~s}, 3 \mathrm{H}, \mathrm{CH}_{3}\right), 1.10\left(\mathrm{~s}, 3 \mathrm{H}, \mathrm{CH}_{3}\right), 1.21\left(\mathrm{~s}, 3 \mathrm{H}, \mathrm{CH}_{3}\right), 1.13-1.28(\mathrm{~m}$, party obscured, $5 \mathrm{H}), 1.34-1.42(\mathrm{~m}, 1 \mathrm{H}), 1.66-1.86(\mathrm{~m}), 1.95$ (ddd, J 4/1 1/13 Hz), 2.13 (ddd. J 4/9/13 Hz), 2.39 (ddd, J 4/11/13 Hz, 1.662.39 combined $11 \mathrm{H}$ ), 2.65-2.69 (m, $1 \mathrm{H}), 2.88-3.18(\mathrm{~m}), 3.40$ (ddd, J $4 / 11 / 13 \mathrm{~Hz}, 2.88-3.40$ combined $2 \mathrm{H}$ ), 3.84, 3.85, 3.87 ( $3 \times \mathrm{s}$, combined $6 \mathrm{H}$ $2 \times \mathrm{OCH}_{3}$ ), 4.44 (dd, J $\sim 5 / 13 \mathrm{~Hz}, 0.75 \times 1 \mathrm{H}, \mathrm{NCH}_{2} \mathrm{CH}_{2} \mathrm{Ar}$ ), 4.52 (dd, J $\left.5 / 13 \mathrm{~Hz}, 0.25 \times 1 \mathrm{H}, \mathrm{NCH}_{2} \mathrm{CH}_{2} \mathrm{Ar}\right), 5.31(\mathrm{l}, \mathrm{J} \sim 7 \mathrm{~Hz}, 0.25 \times 1 \mathrm{H}, \mathrm{NCHAr})$.
5.49 (t. J $\sim 7.3 \mathrm{~Hz}, 0.75 \times 1 \mathrm{H}, \mathrm{NCHAr}), 6.57,6.58(2 \times \mathrm{s}$, combined $2 \mathrm{H}$, Ar-H). Ratio of atropisomers $\sim 25 / 75$.

Hydrogenation of (R)-13a (10 mg, $0.021 \mathrm{mmol})$ with $\mathrm{PtO}_{2}(16 \mathrm{mg})$ in $\mathrm{CH}_{3} \mathrm{OH} / \mathrm{HCl}(2.2 \mathrm{ml}, 10 / 1)$ followed by usual work-up yielded a product that was identical with (R)-15 according to $400 \mathrm{MHz}$ - ' $\mathrm{H}$-NMR-spectrum and TLC.

(IS, 4R)-1-\{(IR)-1-12-(4-Chlorophenyl)-1-ethyl]-1,2,3,4-tetrahydro-6,7dimethoxy-2-isoquinolylcarbonyl]-4,7.7-trimethyl-2-oxa-bicyclo[2.2.1] heptan-3-one (R)-13b and (IS, 4R)-1-\{(IS)-1-[2-(4-Chlorophenyl)1-ethyl]-1,2,3,4-tetrahydro-6,7-dimethoxy-2-isoquinolylcarbonyl\}. 4,7.7-trimethyl-2-oxa-bicyclo/2.2.1 Jheptan-3-one(S)-14b

From $1.0 \mathrm{~g}(1.90 \mathrm{mmol})$ of $(\mathrm{R})-8 \mathrm{~b} /(\mathrm{S})-9 \mathrm{~b}(85.2 / 14.8)$ as described for (R)-13a/(S)-14a. Time of hydrogenation $44 \mathrm{~h}$. The crude product contained a mixture of diastereomers $(R)-13 b$ and $(S)-14 b$ contaminated with a mixture of $(R)-13 a$ and $(S)-14 a$. The portion composed of $(R)-13 a+(S)-14 a$ amounted to about one third of the whole product. The ratio of $(R)-132 /(S)$. 142 was determined as $94.4 / 5.6$ by HPLC. Ratio of $(R)-13 \mathrm{~b} /(\mathrm{S})-14 \mathrm{~b}$ (determined by HPLC on $\mathrm{SiO}_{2}$, n-hexane/ethyl ether $=85 / 15$ ): Table 4, entry 2 . The subsequent $\mathrm{CC}$ (n-hexane/ethyl acetate $=7 / 3$ ) resulted in only incomplete separation. $52 \mathrm{mg}(5.32 \%$, de $>99.5 \%)$ of (R)-13b (used for analytical purposes only), $8 \mathrm{mg}(0.8 \%$ ) of ( $\mathrm{S}$ )-14b and $505 \mathrm{mg}$ ( $51.86 \%$ ) of a mixture of $(R)-13 a /(R)-13 b(\sim 33 / 66)$ were obtained.

(R)-13b: Colorless crystals, m.p. $77-80^{\circ} \mathrm{C},[\alpha]_{546}=-114.3^{\circ},[\alpha]_{578}=-$ $102.9^{\circ}\left(\mathrm{c}=0.17, \mathrm{CH}_{3} \mathrm{OH}\right),-\mathrm{C}_{29} \mathrm{H}_{34} \mathrm{ClNO}_{5}(512.0) \mathrm{Calc}$. C $68.0 \mathrm{H} 6.69 \mathrm{~N}$ 2.7 Found C 68.1 H 6.79 N 2.8. Molmass 512 (MS). - IR: 1790; 1640; $1520 \mathrm{~cm}^{-1}$. - $400 \mathrm{MHz}$ - ${ }^{1} \mathrm{H}$-NMR: 0.97 (s, $\left.0.7 \times 3 \mathrm{H}, \mathrm{CH}_{3}\right), 1.06(\mathrm{~s}, 0.3 \times$ $\left.3 \mathrm{H}, \mathrm{CH}_{3}\right), 1.10\left(\mathrm{~s}, 0.7 \times 3 \mathrm{H}, \mathrm{CH}_{3}\right), 1.12\left(\mathrm{~s}, 0.3 \times 3 \mathrm{H}, \mathrm{CH}_{3}\right), 1.22(\mathrm{~s}, 0.7 \times$ $\left.3 \mathrm{H}, \mathrm{CH}_{3}\right), 1.23\left(\mathrm{~s}, 0.3 \times 3 \mathrm{H}, \mathrm{CH}_{3}\right), 1.70-1.78(\mathrm{~m}, \mathrm{lH}), 1.81-1.99(\mathrm{~m}, \mathrm{lH})$, 2.02-2.17 (m, 3H), 2.38 (ddd, $\sim$ 4/11/13 Hz, 1H), 2.55-2.71 (m), 2.80 (ddd, J 5/11/14 Hz), 2.91-3.23 (m), 3.47 (dt, J 4/13 Hz, 2.55-3.47 comb. $5 \mathrm{H}$ ), 3.83 (s, $\left.0.7 \times 3 \mathrm{H}, \mathrm{OCH}_{3}\right), 3.84\left(\mathrm{~s}, 3 \mathrm{H}, \mathrm{OCH}_{3}\right), 3.86(\mathrm{~s}, 0.3 \times$ $\left.3 \mathrm{H}, \mathrm{OCH}_{3}\right), 4.48\left(\mathrm{dd}, \mathrm{J} \sim 5 / 13 \mathrm{~Hz}, 1 \mathrm{H}, \mathrm{NCH}_{2} \mathrm{CH}_{2} \mathrm{Ar}\right) .5 .41(\mathrm{t}, \mathrm{J} \sim 7 \mathrm{~Hz}, 0.3$ $\times 1 \mathrm{H}, \mathrm{NCHAr}), 5.61$ (dd, $\mathrm{J} \sim 5 / 9 \mathrm{~Hz}, 0.7 \times 1 \mathrm{H}, \mathrm{NCHAr}), 6.53(\mathrm{~s}, 0.7 \times 1 \mathrm{H}$, Ar-H), $6.56(\mathrm{~s}, 0.3 \times 1 \mathrm{H}, \mathrm{Ar}-\mathrm{H}), 6.58(\mathrm{~s}, 0.7 \times 1 \mathrm{H}, \mathrm{Ar}-\mathrm{H}), 6.59(\mathrm{~s}, 0.3 \times 1 \mathrm{H}$, Ar-H), 7.12-7.25 (m, 4H, $\left.\mathrm{C}_{6} \mathrm{H}_{4}-\mathrm{Cl}\right)$. Ratio of atropisomers $-3 /$.

(S)-14b: Colorless crystals, - $400 \mathrm{MHz}-{ }^{1} \mathrm{H}-\mathrm{NMR}\left(\mathrm{CDCl}_{3}\right): 1.09$ (s. 3H, $\mathrm{CH}_{3}$ ), 1.13 (s, 3H, $\mathrm{CH}_{3}$ ), 1.19 (s, 3H, $\mathrm{CH}_{3}$ ), 1.73 (ddd, J 4/9/13 Hz, IH), 1.94 (ddd, J 4/11/13 Hz, 1H), 1.98-2.19 (m, 3H), 2.44 (ddd, J 4/11/13 $\mathrm{Hz}, \mathrm{IH}), 2.54-2.76(\mathrm{~m}, 3 \mathrm{H}), 2.85-2.92(\mathrm{~m}, \mathrm{HH}), 3.51-3.60(\mathrm{~m}, \mathrm{IH}), 3.82$, $3.83\left(2 \times \mathrm{s}\right.$, combined $\left.6 \mathrm{H}, 2 \times \mathrm{OCH}_{3}\right), 4.62$ (dd, J $\sim 5 / 14 \mathrm{~Hz}, 1 \mathrm{H}$, $\mathrm{NCH}_{2} \mathrm{CH}_{2} \mathrm{Ar}$ ), 5.71 (dd, $\left.\mathrm{J} \sim 4 / 10 \mathrm{~Hz}, 1 \mathrm{H}, \mathrm{NCHAr}\right), 6.52,6.56$ ( $2 \times \mathrm{s}$, combined $2 \mathrm{H}, \mathrm{Ar}-\mathrm{H}), 7.12-7.35\left(\mathrm{~m}, 4 \mathrm{H},-\mathrm{C}_{6} \mathrm{H}_{4} \mathrm{Cl}\right)$. The signals of the minor atropisomer have been omitted.

(IS, 4R)-1-\{(IR)-1,2,3,4-Tetrahydro-6,7-dimethoxy-1-12-(3,4-dimethoxyphenyl)-1-ethyl]-2-isoquinolylcarbonyl)-4,7,7-trimethyl-2-oxa-bicyclo12.2.17heptan-3-one $(R)-13 \mathrm{c}$ and

(IS, 4R)-1-\{(IS)-1,2,3,4-Tetrahydro-6,7-dimethoxy-1-12-(3,4-dimethoxyphenyl)-1-ethyl]-2-isoquinolylcarbonyl]-4,7,7-trimethyl-2-oxa-bicyclo[2.2.1] heptan-3-one (S)-14c

From $1.25 \mathrm{~g}(2.26 \mathrm{mmol})$ of $(\mathrm{R})-8 \mathrm{c} /(\mathrm{S})-9 \mathrm{c}(82.4 / 17.6)$ as described for (R)-13a/(S)-14a. Time of hydrogenation $16 \mathrm{~h}$. The diastereomeric ratio was determined from the crude product by $\mathrm{HPLC}\left(\mathrm{SiO}_{2}, \mathbf{n}\right.$-hexane/ $/ \mathrm{Et}_{2} \mathrm{O}=$ 40/60; Ratio of (R)-13c/(S)-14c: Table 4, entry 3). Separation of the diastereomers could be effected by CC ( $n$-hexane/ethyl ether $=3 \Pi$; (S)-14c being retained more strongly).

(R)-13c: Colorless crystals. $[\alpha]_{546}=-94.3^{\circ},[\alpha]_{578}=-83.0^{\circ}(c=0.27$, $\mathrm{CH}_{3} \mathrm{OH}$ ), m.p. $79-84^{\circ} \mathrm{C}$, yield $330 \mathrm{mg}(27.1 \%)$. - $\mathrm{C}_{31} \mathrm{H}_{39} \mathrm{NO}_{7}$ (537.6) Calc. C 69.3 H 7.31 N 2.61 Found C 69.3 H 7.40 N 2.7. Mol. mass 537 (MS) IR: $1785 ; 1640 ; 1510 \mathrm{~cm}^{-1}$. $-400 \mathrm{MHz}-{ }^{1} \mathrm{H}-\mathrm{NMR}\left(\mathrm{CDCl}_{3}\right): 0.98(\mathrm{~s}, 0.7 \mathrm{x}$ $\left.3 \mathrm{H}, \mathrm{CH}_{3}\right), 1.06\left(\mathrm{~s}, 0.3 \times 3 \mathrm{H}, \mathrm{CH}_{3}\right), 1.10\left(\mathrm{~s}, 0.7 \times 3 \mathrm{H}, \mathrm{CH}_{3}\right), 1.12(\mathrm{~s}, 0.3 \times$ 
$\left.3 \mathrm{H}, \mathrm{CH}_{3}\right), 1.22\left(\mathrm{~s}, 0.7 \times 3 \mathrm{H}, \mathrm{CH}_{3}\right), 1.23\left(\mathrm{~s}, 0.3 \times 3 \mathrm{H}, \mathrm{CH}_{3}\right), 1.74$ (ddd, J $4 / 9 / 13 \mathrm{~Hz}, 1 \mathrm{H}$ ), 1.83-1.90 (m, 0.3 x 1H), 1.95 (ddd, J 4/11/13 Hz $0.7 \times$ lH), 2.03-2.23 (m, 3H), 2.39 (ddd, J 4/11/13 Hz, 1H), 2.59 (ddd, J 5/1 1/14 Hz), 2.66-2.73 (m), 2.77 (ddd, J 5/11/14 Hz), 2.85-2.91 (m, 2.592.91 combined $3 \mathrm{H}$ ), 3.00 (ddd, J $~ 5 / 11 / 16 \mathrm{~Hz}, 0.3 \times 1 \mathrm{H}$ ), 3.11 (ddd, J $5 / 11 / 16 \mathrm{~Hz}, 0.7 \times$ IH), 3.22 (ddd, J 4/11.5/13 Hz, $0.3 \times 1 \mathrm{H}$ ), 3.49 (ddd, J $\sim 4 / 11.5 / 13 \mathrm{~Hz}, 0.7 \times 1 \mathrm{H}), 3.82,3.83,3.84,3.85,3.86,3.87(6 \times \mathrm{s}$, combined $12 \mathrm{H}, 4 \times \mathrm{OCH}_{3}$ ), 4.47 (dd, J $-5 / 13 \mathrm{~Hz}, 0.7 \times 1 \mathrm{H}, \mathrm{NCH}_{2} \mathrm{CH}_{2} \mathrm{Ar}$ ), 4.53 (ddd, partly obscured, $0.3 \times 1 \mathrm{H}, \mathrm{NCH}_{2} \mathrm{CH}_{2} \mathrm{Ar}$ ), $5.41(\mathrm{t}, \mathrm{J} \sim 7 \mathrm{~Hz}, 0.3 \times 1 \mathrm{H}$, NCHAr), 5.63 (dd, J 5/9 Hz, $0.7 \times 1 \mathrm{H}, \mathrm{NCHAr}$ ), 6.55 (s, $0.7 \times 1 \mathrm{H}, \mathrm{Ar}-\mathrm{H}$ ), $6.59(\mathrm{~s}, 1 \mathrm{H}, \mathrm{Ar}-\mathrm{H}), 6.60(\mathrm{~s}, 0.3 \times 1 \mathrm{H}, \mathrm{Ar}-\mathrm{H}), 6.72-6.80(\mathrm{~m}, 3 \mathrm{H}$, $\left.\mathrm{C}_{6} \mathrm{H}_{3}(\mathrm{OMe})_{2}\right)$. Ratio of atropisomers $\sim 3 /$.

(S)-14c (only minute amounts from $\mathrm{CC}$ ): $400 \mathrm{MHz}-{ }^{1} \mathrm{H}-\mathrm{NMR}\left(\mathrm{CDCl}_{3}\right)$ : $1.10\left(\mathrm{~s}, 3 \mathrm{H}, \mathrm{CH}_{3}\right), 1.13\left(\mathrm{~s}, 3 \mathrm{H}, \mathrm{CH}_{3}\right), 1.20\left(\mathrm{~s}, 3 \mathrm{H}, \mathrm{CH}_{3}\right), 1.73$ (ddd, J $4 / 9 / 13 \mathrm{~Hz}, 1 \mathrm{H}$ ), 1.94 (ddd, J 4/11/13 Hz, 1H), 2.01-2.16 (m, 3H), 2.45 (ddd, J 4/1 1/13 Hz, lH), 2.54-2.77 (m, 3H), 2.89 (ddd, J 6/12/17 Hz. 1H), 3.59 (ddd, J 4/12/14.5 Hz, 1H), 3.82, 3.84, 3.85, 3.88 (4 x s, combined 12H, $4 \times \mathrm{OCH}_{3}$ ). 4.62 (dd, unresolved, $1 \mathrm{H}, \mathrm{NCH}_{2} \mathrm{CH}_{2} \mathrm{Ar}$ ), 5.73 (dd, J $\sim 4.4 / 10.2 \mathrm{~Hz}, 1 \mathrm{H}, \mathrm{NCHAr}), 6.54$ (s, 1H, Ar-H), 6.56 (s, 1H, Ar-H), 6.71$6.81\left(\mathrm{~m}, 3 \mathrm{H},-\mathrm{C}_{6} \mathrm{H}_{3}(\mathrm{OMe})_{2}\right)$. The signals of the minor atropisomer have been omitted.

\section{Secondary Amines $(R)-16 \mathrm{a}-\mathrm{c}$ and $(S)-16 \mathrm{a}$}

(IR)-1,2,3,4-Tetrahydro-6,7-dimethoxy-1-(2-phenyl-1-ethyl)isoquinoline (R)-16a and

(IS. 3R)-1-I(IR)-1, 2,3,4-Tetrahydro-6,7-dimethoxy-1-12-phenyl-1-ethyl)2-isoquinolyl-methyl]-3-hydroxymethyl-2,2,3-trimethyl-1-cyclopentanol (R)-17

$303 \mathrm{mg}(0.633 \mathrm{mmol})$ of $(\mathrm{R})-13 \mathrm{a}$ were dissolved in $15 \mathrm{ml}$ of THF. At room temp. $2.16 \mathrm{ml}$ of a solution of $\mathrm{LiAlH}_{4}(1 \mathrm{M}$ in THF) was added slowly. The mixture was stirred for $3 \mathrm{~h}$ and then quenched with water $(6 \mathrm{ml})$. Then it was concentrated in vacuo and acidified with $2 \mathrm{~N} \mathrm{HCl}$. The aqueous layer was extracted once with ethyl ether and the org. extract was discharged. After the water phase had been made alkaline by $\mathrm{NaOH}$ it was extracted with ethyl ether (3x). The org. layers were dried $\left(\mathrm{MgSO}_{4}\right)$ and the solvent was evaporated in vacuo. From the residue (R)-16a and (R)-17a were obtained by $\mathrm{CC}\left(\mathrm{SiO}_{2}\right.$, ethyl ether $/ \mathrm{NE}_{3}=95 / 5$; order of elution: 1 . (R)-17: 2. (R)-16a.

(R)-16a: Colorless oil, $[\alpha]_{546}=+26.8^{\circ},[\alpha]_{578}=+25.5^{\circ} \quad(\mathrm{c}=0.75$, $\mathrm{CH}_{3} \mathrm{OH}$ ), yield $121 \mathrm{mg}(64.5 \%)$. - $\mathrm{C}_{19} \mathrm{H}_{23} \mathrm{NO}_{2}$ (297.4) Calc. C $76.7 \mathrm{H} 7.79$ N 4.7 Found C 76.6 H 7.96 N 4.8. Mol.mass 297 (MS). - IR: 3330; 2940; $1510 \mathrm{~cm}^{-1}$. - $400 \mathrm{MHz}$ - ${ }^{1} \mathrm{H}-\mathrm{NMR}$ : 1.89 (s, broad, $1 \mathrm{H}, \mathrm{NH}$ ), 1.99-2.17 (m, $2 \mathrm{H}$ ), 2.64-2.88 (m, 4H), 3.00 (ddd, $\mathrm{J}=5.1 / 7.3 / 12.5 \mathrm{~Hz}, 1 \mathrm{H}, \mathrm{NCH}_{2} \mathrm{CH}_{2} \mathrm{Ar}$ ), $3.25\left(\mathrm{dt}, \mathrm{J}=12.5 / 5.5 \mathrm{~Hz}, 1 \mathrm{H}, \mathrm{NCH}_{2} \mathrm{CH}_{2} \mathrm{Ar}\right), 3.82,3.84(2 \times \mathrm{s}$, combined $\left.6 \mathrm{H}, 2 \times \mathrm{OCH}_{3}\right), 3.96(\mathrm{dd}, \mathrm{J}=3.3 / 8.8 \mathrm{~Hz}, 1 \mathrm{H}, \mathrm{NCHAr}), 6.57(\mathrm{~s}, 2 \mathrm{H}, \mathrm{Ar}-\mathrm{H})$, 7.17-7.31 (m, $\left.5 \mathrm{H},-\mathrm{C}_{6} \mathrm{H}_{5}\right)$.

(R)-17: Colorless crystals, m.p. $51-56^{\circ} \mathrm{C},[\alpha]_{546}=-32.9^{\circ},[\alpha]_{578}=-27.4^{\circ}$ $\left(c=0.37, \mathrm{CH}_{2} \mathrm{Cl}_{2}\right.$ ), yield $90 \mathrm{mg}(30.4 \%),-\mathrm{C}_{29} \mathrm{H}_{41} \mathrm{NO}_{4}(467.6)$ Calc. C 72.3 H 8.16 N 2.9 Found C 72.1 H 8.41 N 2.9 Mol.mass 467 (MS). - IR: 3550 3200; 2950; $1520 \mathrm{~cm}^{-1}$. - $400 \mathrm{MHz}$ - ' H-NMR: 0.68 (s, 3H, $\mathrm{CH}_{3}$ ), 0.83 (s, $\left.3 \mathrm{H}, \mathrm{CH}_{3}\right), 0.88\left(\mathrm{~s}, 3 \mathrm{H}, \mathrm{CH}_{3}\right), 1.46$ (ddd, J 4/10/13 Hz, 1H), 1.75-1.87 (m, $2 \mathrm{H}), 1.89-2.00(\mathrm{~m}, \mathrm{lH}), 2.02-2.12(\mathrm{~m}, 1 \mathrm{H}), 2.15-2.23(\mathrm{~m}, 1 \mathrm{H}), 2.42-2.59$ (m, 3H), 2.64-2.78 (m, 1H), 2.81-2.98 (m, 3H), $3.11(\mathrm{dd}, \mathrm{J} \sim 9 / 11 \mathrm{~Hz}, 1 \mathrm{H})$, 3.39 (dt, J 13/4 Hz, 1H), 3.58-3.64 (m, 2H), 3.84, 3.85 ( 2 x s, combined $\left.6 \mathrm{H}, 2 \times \mathrm{OCH}_{3}\right), 5.53-5.57(\mathrm{~m}, 2 \mathrm{H}), 6.49(\mathrm{~s}, 1 \mathrm{H}, \mathrm{Ar}-\mathrm{H}), 6.58(\mathrm{~s}, 1 \mathrm{H}, \mathrm{Ar}-\mathrm{H})$, 7.16-7.31 (m, $\left.5 \mathrm{H},-\mathrm{C}_{6} \mathrm{H}_{5}\right)$.

\section{(IS)-1,23,4-Tetrahydro-6,7-dimethoxy-1-(2-phenyl-1-ethyl)isoquinoline} (S)-16a

The same procedure as described for the synthesis of (R)-16a was applied for the reductive cleavage of $(S)-14 a(44 \mathrm{mg}, 0.091 \mathrm{mmol}$ ) with
$\mathrm{LiAlH}_{4}(0.31 \mathrm{ml} \mathrm{M}$ solution). (S)-16a was isolated as a colorless oil. $[\alpha]_{546}=-24.5^{\circ},[\alpha]_{578}=-22.0^{\circ}\left(c=0.77, \mathrm{CH}_{3} \mathrm{OH}\right)$, yield $17 \mathrm{mg}(63.0 \%)$. NMR-, IR- and MS-data correspond to those observed for (R)-16a.

\section{(IR)-1-[2-(4-Chlorophemyl)-1-ethyl]-1,2,3,4-tetrahydro-6,7-dimethoxy-} isoquinoline $(R)-16 \mathrm{~b}$

From a mixture of $(R)-13 \mathrm{a} /(R)-13 \mathrm{~b}$ (200 mg, $0.391 \mathrm{mmol}$ based on $(R)$ $13 \mathrm{~b}$ ) and $2.0 \mathrm{ml}$ of a M LiAlH 4 solution as described for (R)-16a. Separation of (R)-16b from the accompanying $(R)-16 a$ (which had also been formed) was accomplished by $\mathrm{CC}$ (ethyl ether $/ \mathrm{NE}_{3}=98 / 2$; $(R)-16 \mathrm{~b}$ being retained more strongly). Colorless oil, $[\alpha]_{546}=+11.5^{\circ},[\alpha]_{578}=+12.4^{\circ}$ $\left(c=1.05, \mathrm{CH}_{3} \mathrm{OH}\right)\left[\right.$ ref. $^{19)}:[\alpha]_{\mathrm{D}}=+12.3^{\circ}(\mathrm{c}=0.25)$, yield $21 \mathrm{mg}(16.1 \%)$. $400 \mathrm{MHz}-{ }^{1} \mathrm{H}-\mathrm{NMR}\left(\mathrm{CDCl}_{3}\right): 1.60$ (s, broad, $\left.1 \mathrm{H}, \mathrm{NH}\right), 1.95-2.09(\mathrm{~m}, 2 \mathrm{H})$, 2.62-2.83 (m, 4H), 2.99 (ddd, J 5//12 Hz, 1H, $\mathrm{NCH}_{2} \mathrm{CH}_{2} \mathrm{Ar}$ ), 3.22 (dh, J $\left.\sim 12.5 / 5.5 \mathrm{~Hz}, 1 \mathrm{H}, \mathrm{NCH}_{2} \mathrm{CH}_{2} \mathrm{Ar}\right), 3.82,3.84(2 \times \mathrm{s}$, combined $6 \mathrm{H}, 2 \times$ $\left.\mathrm{OCH}_{3}\right), 3.93$ (dd, J = 3.3/8.8 Hz, 1H, NCHAr), 6.55 (s, $\left.1 \mathrm{H}, \mathrm{Ar}-\mathrm{H}\right), 6.57$ (s, IH, Ar-H), 7.13-7.17, 7.23-7.29 (2 x m, combined 4H, $\left.-\mathrm{C}_{6} \mathrm{H}_{4} \mathrm{Cl}\right)$.

(IR)-1,2,3,4-Tetrahydro-6,7-dimethoxy-1-[2-(3,4-dimethoxyphenyl)-1. ethyl]-isoquinoline $(R)-16 \mathrm{c}$

From $190 \mathrm{mg}$ ( $0.353 \mathrm{mmol}$ ) of (R)-13c in $4 \mathrm{ml}$ of THF and $1.13 \mathrm{ml}$ of a $\mathrm{M} \mathrm{LiAlH}_{4}$ solution as described for (R)-16a. Reaction time $2 \mathrm{~h}$. Purification by $\mathrm{CC}$ (ethyl ether/EtMe $\mathrm{N}=9 / 1$ ). Colorless oil, $[\alpha]_{546}=+13.5^{\circ}$, $[\alpha]_{578}=+15.1^{\circ}\left(c=0.59, \mathrm{CH}_{3} \mathrm{OH}\right)$, yield $97 \mathrm{mg}(77.0 \%) .-\mathrm{C}_{21} \mathrm{H}_{27} \mathrm{NO}_{4}$ (357.4) Calc. C 70.6 H 7.61 N 3.9 Found C 70.4 H 7.72 N 4.1. Mol.mass 357 (MS). - IR: 3320; 2940; $1510 \mathrm{~cm}^{-1}$ - $400 \mathrm{MHz}$ - 'H-NMR ( $\left.\mathrm{CDCl}_{3}\right)$ : 1.63 (s, broad, $1 \mathrm{H}, \mathrm{NH}), 1.96-2.15(\mathrm{~m}, 2 \mathrm{H}), 2.63-2.82(\mathrm{~m}, 4 \mathrm{H}), 2.99$ (ddd, J $\sim 5 / 7 / 12.5 \mathrm{~Hz}, 1 \mathrm{H}, \mathrm{NCH}_{2} \mathrm{CH}_{2} \mathrm{Ar}$ ), 3.24 (d., J $\sim 12.5 / 5 \mathrm{~Hz}, 1 \mathrm{H}$, $\left.\mathrm{NCH}_{2} \mathrm{CH}_{2} \mathrm{Ar}\right), 3.82,3.84,3.85,3.86\left(4 \times \mathrm{s}\right.$, combined $\left.12 \mathrm{H}, 4 \times \mathrm{OCH}_{3}\right)$, 3.95 (dd, J 3/8.8 Hz, 1H, NCHAs), 6.57, 6.58 (2x s, combined $2 \mathrm{H}, 2 \mathrm{x}$ Ar- $\mathrm{H}), 6.76-6.81\left(\mathrm{~m}, 3 \mathrm{H},-\mathrm{C}_{6} \mathrm{H}_{3}(\mathrm{OMe})_{2}\right)$.

(IR)-1,2,3,4-Tetrahydro-6,7-dimethoxy-1-12-(3,4-dimethoxyphenyl)-1ethyl]-2-methylisoquinoline $(R)-18$

$28 \mathrm{mg}(0.079 \mathrm{mmol})$ of (R)-16c were dissolved in $5.8 \mathrm{ml}$ of $\mathrm{CH}_{3} \mathrm{OH}$. At room temp. and under stirring, $32 \mu \mathrm{l}$ of a $\mathrm{H}_{2} \mathrm{CO}$ solution (37\%) and $25 \mathrm{mg}$ $(0.396 \mathrm{mmol})$ of $\mathrm{NaCNBH}_{3}$ were added. The reaction mixture was adjusted to $\mathrm{pH} 5.7$ by repeated addition of acetic acid. After $19 \mathrm{~h}$ the solvent was evaporated in vacuo and $0.8 \mathrm{ml}$ of $\mathrm{N} \mathrm{NaOH}$ were added. The aqueous phase was saturated with $\mathrm{NaCl}$ and then extracted with ethyl ether (3x). The combined org. layers were dried over $\mathrm{MgSO}_{4}$ and concentrated in vacuo. The product was purified by $\mathrm{CC}$ (ethyl ether $/ \mathrm{NEt}_{3}=9 / 1$ ). Colorless oil, $[\alpha]_{546}=-20.2^{\circ},[\alpha]_{578}=-13.5^{\circ}\left(c=0.89, C_{2} \mathrm{H}_{5} \mathrm{OH}\right)$, [ref. ${ }^{5)}(S)-18:[\alpha]_{D}$ $\left.=+11^{\circ}\left(c=0.21, \mathrm{C}_{2} \mathrm{H}_{5} \mathrm{OH}\right)\right]$. - The ${ }^{1} \mathrm{H}-\mathrm{NMR}$-data correspond to those reported ${ }^{\text {s) }}$ for (R)-18.

\section{(IR, 3R, 4S)-3-Menthyl-(1,2,3,4-tetrahydro-6,7-dimethoxy-2-isoquinoline} carboxylate) 20

To a suspension of $800 \mathrm{mg}$ ( $3.48 \mathrm{mmol}$ ) of 5 in $15 \mathrm{ml}$ of $\mathrm{CH}_{2} \mathrm{Cl}_{2} 1.057 \mathrm{~g}$ (10.45 mmol) of $\mathrm{NEt}_{3}$ were added at room temp. followed (after cooling to $0^{\circ} \mathrm{C}$ ) by the addition of $914 \mathrm{mg}(4.18 \mathrm{mmol})$ of 19 . After $15 \mathrm{~min}$ the $\mathrm{mix}$ ture was allowed to warm to room temp. and stiring was continued for 3.5 h. The reaction mixture was washed with $0.05 \mathrm{M} \mathrm{HCl}(3 x)$ and saturated $\mathrm{NaCl}$-solution ( $3 \mathrm{x}$ ) and dried over $\mathrm{MgSO}_{4}$. The solvent was evaporated in vacuo and the residue purified by $\mathrm{CC}$ ( $n$-hexane/ethyl ether $=1 / 1)$. Colorless oil, $[\alpha]_{546}=-72.5^{\circ},[\alpha]_{578}=-63.7^{\circ}\left(\mathrm{c}=0.91, \mathrm{CH}_{3} \mathrm{OH}\right)$, yield $1.23 \mathrm{~g}$ (94.0\%). - $\mathrm{C}_{22} \mathrm{H}_{33} \mathrm{NO}_{4}$ (375.5) Calc. C $70.4 \mathrm{H} 8.86 \mathrm{~N} 3.7$ Found $\mathrm{C} 70.4 \mathrm{H}$ 8.87 N 3.7. Mol.mass 375 (MS). - IR: $1690 ; 1520 \mathrm{~cm}^{-1}$. - $400 \mathrm{MHz}$ - ${ }^{1} \mathrm{H}-$ NMR $\left(\mathrm{CDCl}_{3}\right): 0.78(\mathrm{~d}, \mathrm{~J} \sim 7 \mathrm{~Hz}, 3 \mathrm{H}), 0.89(\mathrm{~d}, \mathrm{~J} \sim 7 \mathrm{~Hz}, 3 \mathrm{H}), 0.90$ (d, J $~ 7$ $\mathrm{Hz}, 3 \mathrm{H}$ ), 0.85-0.92 (m, signal obscured, $1 \mathrm{H}$ ), 0.92-1.15, 1.20-1.30, 1.381.55, 1.65-1.72 (4 x m, combined $7 \mathrm{H}), 1.90-1.96(\mathrm{~m}, 1 \mathrm{H}), 2.06-2.12(\mathrm{~m}$, 
1H), 2.76 (s, broad, $2 \mathrm{H}), 3.65-3.70(\mathrm{~m}, 1 \mathrm{H}), 3.85\left(\mathrm{~s}, 6 \mathrm{H}, 2 \times \mathrm{OCH}_{3}\right), 4.55$ (pseudo s, 2H), 4.61 (dt, J $=4 / 10 \mathrm{~Hz}, 1 \mathrm{H}), 6.60,6.62(2 \times \mathrm{s}, 2 \mathrm{H}, \mathrm{Ar}-\mathrm{H}$ ). Only one set of signals has been observed.

(IR, 3R, 4S)-3-Menthyl-I(IR)-1,2,3,4-tetrahydro-6,7-dimethoxy-1-(2-oxo2-phenyl-1-elhyl)-2-isoquinoline carboxylate $](R)-22$ and

(IR, 3R, 4S)-3-Menthyl-[(IS)-1,2,3,4-tetrahydro-6,7-dimethoxy-1-(2-oxo-

2-phenyl-1-ethyl)-2-isoquinoline carboxylate] (S)-23

To a stirred solution of $63 \mathrm{mg}(0.191 \mathrm{mmol})$ of 3 in $1.5 \mathrm{ml}$ of $\mathrm{CH}_{2} \mathrm{Cl}_{2} 60$ $\mathrm{mg}(0.160 \mathrm{mmol})$ of 20 (in $1.5 \mathrm{ml}$ of $\left.\mathrm{CH}_{2} \mathrm{Cl}_{2}\right)$ were added. After stirring for $16 \mathrm{~h}$ at room temp. the mixture was cooled to $-78^{\circ} \mathrm{C}$ and $37 \mathrm{mg}(0.190$ mmol) of $7 \mathrm{a}$ were added. Then stirring was continued for $3 \mathrm{~h}$ at $-78^{\circ} \mathrm{C}$ whereafter the mixture was quenched with $3 \mathrm{ml}$ of $\mathrm{H}_{2} \mathrm{O}$. The org. phase was washed with saturated $\mathrm{NaCl}$-solution (3x), dried over $\mathrm{MgSO}_{4}$ and the solvent was evaporated in vacuo. The diastereomers (R)-22/(S)-23 proved to be inseparable on $\mathrm{SiO}_{2}$ and were obtained as a mixture after $\mathrm{CC}\left(\mathrm{SiO}_{2}\right.$, $\mathrm{n}$-hexane/ethyl ether $=1 / 1$ ). HPLC-analysis of the crude product revealed a diastereomeric ratio of about $1 / 1$ (chiral column, $n$-hexane/isopropanol = 9/1; incomplete peak separation). Colorless crystals, m.p. $42-54^{\circ} \mathrm{C}$, yield 62 $\mathrm{mg}$ (78.0\%). $-\mathrm{C}_{30} \mathrm{H}_{39} \mathrm{NO}_{5}$ (493.6) Calc. C $73.0 \mathrm{H} 7.96 \mathrm{~N} 2.8$ Found $\mathrm{C} 73.2$ H 7.75 N 2.8. Mol.mass 493 (MS). - IR: 1690;1670; $1520 \mathrm{~cm}^{-1}$. For analytical purposes a sample of (R)-22/(S)-23 was separated by prep. HPLC on a chiral column (n-hexane/isopropanol $=9 / 1$ ).

Isomer 1 (being retained less strongly): $400 \mathrm{MHz}-{ }^{1} \mathrm{H}-\mathrm{NMR}\left(\mathrm{CDCl}_{3}\right)$ : 0.63-1.10 (m, 11H), 1.20-1.50 (m, 3H), 1.64-2.17 (m, 4H), 2.72-2.92 (m, $2 \mathrm{H}), 3.22-3.60(\mathrm{~m}, 3 \mathrm{H}) ; 3.75,3.84\left(2 \times \mathrm{s}\right.$, combined $\left.6 \mathrm{H}, 2 \times \mathrm{OCH}_{3}\right), 3.86-$ 3.95, 4.10-4.20 (2 $\times \mathrm{m}$, combined $1 \mathrm{H}), 4.48-4.60(\mathrm{~m}, \mathrm{lH})$, 5.65-5.80 $(\mathrm{m}$, 1H), 6.61, 6.66 (2 x s, combined $2 \mathrm{H}, \mathrm{Ar}-\mathrm{H}), 7.44-7.57$ (m, 3H, Ar-H), 7.91$8.01(\mathrm{~m}, 2 \mathrm{H}, \mathrm{Ar}-\mathrm{H})$. The signals reported arise from rotational isomers that are present in about equal amounts.

Isomer 2: $400 \mathrm{MHz}-{ }^{1} \mathrm{H}-\mathrm{NMR}\left(\mathrm{CDCl}_{3}\right)$ : 0.62-1.00 (m, $\left.11 \mathrm{H}\right), 1.20-1.43$ (m, 3H), 1.59-2.05 (m, 4H), 2.72-2.92 (m, 2H), 3.24-3.50 (m, 3H), 3.75, $3.78,3.84,3.85\left(4 \times\right.$ s, combined $\left.6 \mathrm{H}, 2 \times \mathrm{OCH}_{3}\right), 3.90-4.00,4.10-4.20(2 \times$ $\mathrm{m}$, combined $1 \mathrm{H}), 4.49-4.55(\mathrm{~m}, 1 \mathrm{H}), 5.68-5.74(\mathrm{~m}, 1 \mathrm{H}), 6.59-6.70(\mathrm{~m}, 2 \mathrm{H}$, Ar-H), 7.45-7.58 (m, 3H, Ar-H), 7.91-8.02 (m, 2H, Ar- $\mathrm{H})$. The signals reported arise from rotational isomers that are present in about equal amounts.

\section{References and Footnotes}

1 Part VI: K. Th. Wanner and I. Praschak, Heterocycles 29, 29 (1989).

2 a) F. Külz and C. Schopf, D.R.P. 726 173, C.A. 37, 6277 (1943); b) F. Kulz, D.R.P. 728 326, C.A. 37,6675 (1943); c) F. Kül, D.R.P. 732 502, C.A. 38,753 (1944).
3 A. Brossi. H. Besendorf, L.A. Pirk, and A. Rheiner: "Isoquinoline Analgetics". In: Analgetics, Medicinal Chemistry (G. deStevens, ed.), Vol. 5, p. 281, Academic Press, London 1965.

4 T. Kametani and M. Koizumi: "Phenethylisoquinoline Alkaloids". In: The alkaloids (R. Manske, ed.) Vol. XIV, p. 265, Academic Press, London 1979.

5 A.J. Aledesanmi, Ch. J. Kelley, and J.D. Ceasy, J. Nat. Prod. 46, 127 (1983).

6 For a survey of the presently available methods see: J.M.P. Huber and D. Seebach, Helv. Chim. Acta 70, 1944 (1987). See also: M. Yamato, K. Hashigaki, s. Ishikawa, and N. Qais, Tetrahedron Lett. 29, 6949 (1988).

7 K. Th. Wanner and G. Höfner, Arch. Pharm. (Weinheim) 322, 99 (1989).

8 K. Th. Wanner, A. Kärtner, and E. Wadenstorfer, Heterocycles 27, 2549 (1988) and references cited therein.

9 For a short communication see reference ${ }^{1)}$.

10 T. Shono: "Electroorganic Chemistry as a New Tool in Organic Synthesis", p. 63, Springer-Verlag, Berlin 1984.

11 M. Onda, K. Yuasa, and J. Okada, Chem. Pharm. Bull. 22, 2365 (1974).

12 For similar oxidation reactions utilizing triphenylcarbenium perchlorate see: T.V. Stupnikova, A.K. Sheinkman, L.A. Rybenko, and N.A. Klynev, Khim. Geterotsikl. Soedin. 1978, 251; C.A. 88, 190638b (1978).

13 H.E. Zaugg, Synthesis 1984, 181.

14 P.D. Palasz, J.H.P. Utley, and J.D. Hardstone, J. Chem. Soc. Perkin Trans. II, 1984, 807.

15 Further details of the crystal structure investigation are available on request from the Fachinformationszentrum Energie, Physik. Mathematik GmbH, D-7514 Eggenstein-Leopoldshofen 2, on quoting the depository number CSD 53835, the names of the authors and the journal citation.

16 The structure was solved by use of SHELXS 86 and refined with SHELXTL 4.1. Hydrogen atom positions were calculated for idealized geometry with $U_{H}=1.2 \times U_{C} ; R=0.077, R_{W}=0.00784, g=0.0007$, $w=1 /\left(\sigma^{2}\left(F_{0}\right)+g \times F_{0}{ }^{2}\right)$. All atomic positions except those for the tetrafluoroborate anion have been refined without restrictions. The tetrafluoroborate anion has been refined for an idealized tetrahedral geometry.

17 This could be the result of steric hindrance or of stereoelectronic factors as well.

18 K.Th. Wanner and A. Kärtner, Arch. Pharm. (Weinheim) 320, 1253 (1987).

19 A. Brossi and F. Burkhardt, Helv. Chim. Acta 44, 1558 (1961).

20 The separation of diastereomers via a menthyl derived carbamate in a related pyrrolidine system also failed: T. Nagasaka, H. Yamamoto, H. Hayashi, M. Watanabe, and F. Hamaguchi, Heterocycles 29, 155 (1989).

[Ph690] 